Portland State University

PDXScholar

\title{
Revisiting TODs: How Subsequent Development Affects the Travel Behavior of Residents in Existing Transit-Oriented Developments
}

Nathan McNeil

Portland State University, nmcneil@pdx.edu

Jennifer Dill

Portland State University, jdill@pdx.edu

Follow this and additional works at: https://pdxscholar.library.pdx.edu/trec_reports

Part of the Transportation Commons, Urban Studies Commons, and the Urban Studies and Planning Commons

Let us know how access to this document benefits you.

\section{Recommended Citation}

N. McNeil, J. Dill. Revisiting TODs: How Subsequent Development Affects the Travel Behavior of Residents in Existing Transit-Oriented Developments. NITC-RR-1240. Portland, OR: Transportation Research and Education Center (TREC), May, 2020. https://dx.doi.org/10.15760/trec.250

This Report is brought to you for free and open access. It has been accepted for inclusion in TREC Final Reports by an authorized administrator of PDXScholar. Please contact us if we can make this document more accessible: pdxscholar@pdx.edu. 


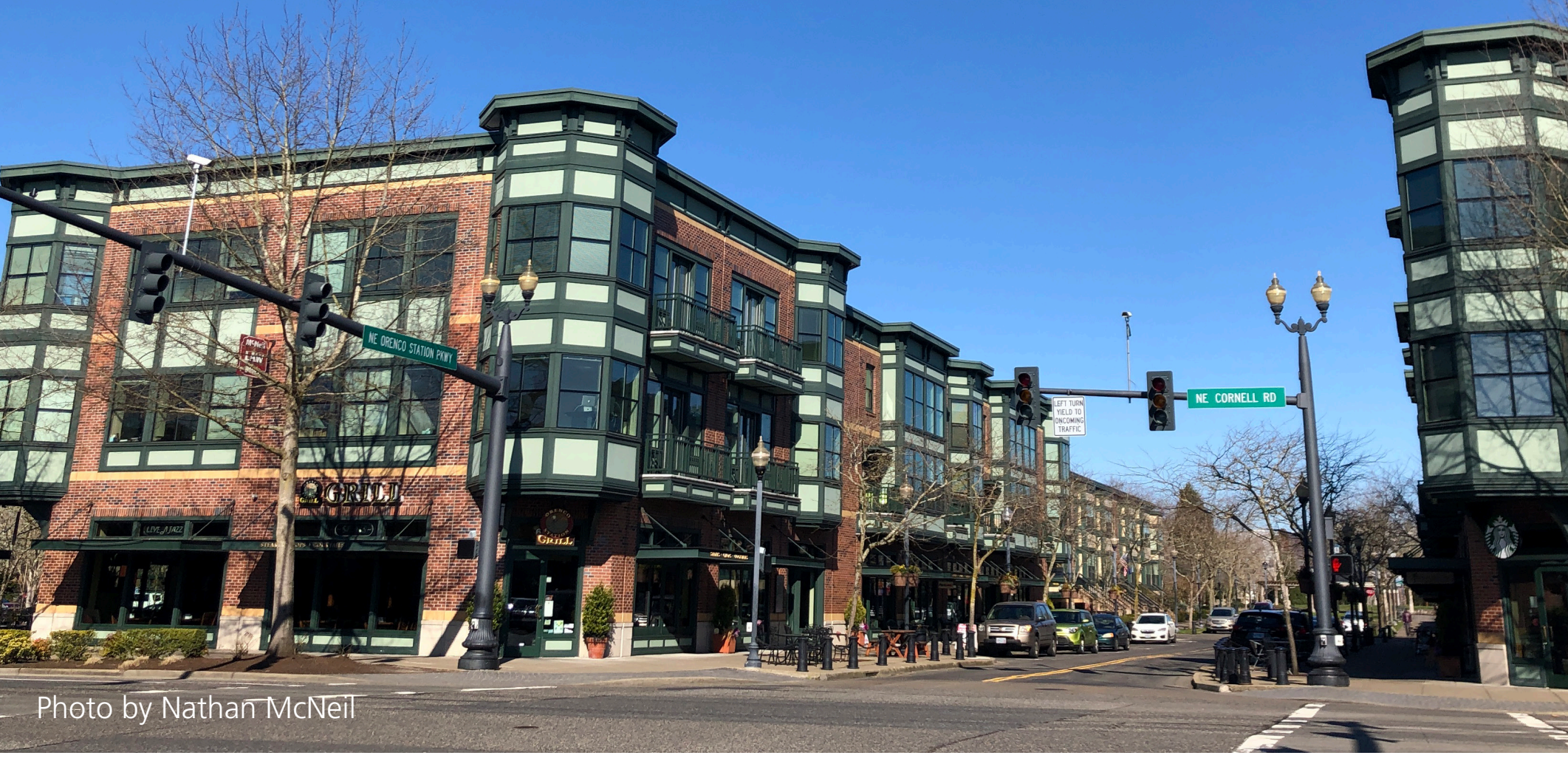

Revisiting TODs: How Subsequent Development Affects the Travel Behavior of Residents in Existing Transit-Oriented Developments

Nathan McNeil, M.U.R.P. Jennifer Dill, Ph.D. 


\title{
REVISITING TODS: HOW SUBSEQUENT DEVELOPMENT AFFECTS THE TRAVEL BEHAVIOR OF RESIDENTS IN TRANSIT- ORIENTED DEVELOPMENTS
}

\author{
FINAL REPORT \\ NITC-RR-1240 \\ by \\ Nathan McNeil \\ Jennifer Dill \\ Portland State University
}

for

National Institute for Transportation and Communities (NITC)

P.O. Box 751

Portland, OR 97207
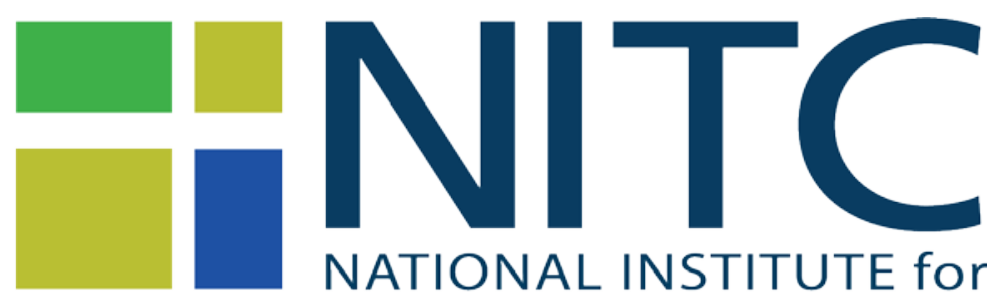

NATIONAL INSTITUTE for

TRANSPORTATION and COMMUNITIES 


\begin{tabular}{|c|c|c|c|c|}
\hline $\begin{array}{l}\text { 1. Report No. } \\
\text { NITC-RR-1240 }\end{array}$ & \multicolumn{2}{|c|}{ 2. Government Accession No. } & \multicolumn{2}{|c|}{ 3. Recipient's Catalog No. } \\
\hline \multirow{2}{*}{\multicolumn{3}{|c|}{$\begin{array}{l}\text { 4. Title and Subtitle } \\
\text { Revisiting TODs: How Subsequent Development Affects the Travel Behavior of } \\
\text { Residents in Existing Transit-Oriented Developments }\end{array}$}} & \multicolumn{2}{|c|}{$\begin{array}{l}\text { 5. Report Date } \\
2020\end{array}$} \\
\hline & & & \multicolumn{2}{|c|}{ 6. Performing Organization Code } \\
\hline \multicolumn{3}{|l|}{$\begin{array}{l}\text { 7. Author(s) } \\
\text { N. McNeil, J. Dill }\end{array}$} & \multicolumn{2}{|c|}{$\begin{array}{l}\text { 8. Performing Organization Report } \\
\text { No. }\end{array}$} \\
\hline \multicolumn{3}{|l|}{ 9. Performing Organization Name and Address } & \multicolumn{2}{|c|}{ 10. Work Unit No. (TRAIS) } \\
\hline \multicolumn{3}{|l|}{ Portland State University } & \multicolumn{2}{|c|}{ 11. Contract or Grant No. } \\
\hline \multicolumn{3}{|l|}{ 12. Sponsoring Agency Name and Address } & \multicolumn{2}{|c|}{$\begin{array}{l}\text { 13. Type of Report and Period } \\
\text { Covered }\end{array}$} \\
\hline \multicolumn{3}{|c|}{$\begin{array}{l}\text { National Institute for Transportation and Communities (NITC) } \\
\text { P.O. Box } 751 \\
\text { Portland, OR } 97207\end{array}$} & \multicolumn{2}{|c|}{ 14. Sponsoring Agency Code } \\
\hline \multicolumn{5}{|l|}{ 15. Supplementary Notes } \\
\hline \multicolumn{5}{|c|}{$\begin{array}{l}\text { 16. Abstract } \\
\text { Portland State University has worked with the Portland Metro regional government periodically since } 2005 \text { to survey occupants of } \\
\text { buildings for which developers had received funding from Metro's Transit-Oriented Development (TOD) Program. This research } \\
\text { extends upon the prior TOD surveys in Portland by revisiting a set of developments with a second wave of surveys to understand } \\
\text { how the travel behavior of TOD residents may change over time, and what factors influence change in travel patterns. The } \\
\text { second-wave surveys, coming 8-13 years after the baseline surveys, include five TODs in the west-side Portland suburbs of } \\
\text { Hillsboro and Beaverton, two TODs in East Portland, and eight TODs in the east-side Portland suburb of Gresham. Second-wave } \\
\text { surveys were sent to the same buildings as the baseline surveys (in most cases, to every unit), but not specifically to the same } \\
\text { people as in the baseline. Surveys asked about household travel options, daily travel for work and non-work purposes, and } \\
\text { questions on travel preferences and attitudes. }\end{array}$} \\
\hline \multicolumn{5}{|c|}{$\begin{array}{l}\text { Our hypothesis was that as neighborhoods are built out, both around the TOD and other transit station areas, residents would } \\
\text { have greater opportunities to use transit (along with walking and bicycling) for daily travel. For the sample as a whole, there were } \\
\text { three changes between the baseline and second-wave surveys that are consistent with the objectives of TODs: the share of } \\
\text { people commuting to work by driving alone four to five days a week fell from } 58 \% \text { to } 46 \% \text {, while the share never driving alone rose } \\
\text { from } 11 \% \text { to } 24 \% \text {; the share of people walking or biking to work at least one day a week rose from } 9 \% \text { to } 29 \% \text {; and the share of } \\
\text { people living in low-car households (fewer cars than adults) increased from } 34 \% \text { to } 50 \% \text {, though the share of car-free household } \\
\text { did not change. We did not see any changes in the overall sample with respect to commuting by transit or using transit, walking, or } \\
\text { bicycling for other, non-commute trip purposes. }\end{array}$} \\
\hline \multicolumn{2}{|c|}{$\begin{array}{l}\text { 17. Key Words } \\
\text { Transit-Oriented Development, TOD, travel, neighborhood }\end{array}$} & \multicolumn{3}{|c|}{$\begin{array}{l}\text { 18. Distribution Statement } \\
\text { No restrictions. Copies available from NITC: } \\
\text { www.nitc-utc.net }\end{array}$} \\
\hline $\begin{array}{l}\text { 19. Security Classification (of this report) } \\
\text { Unclassified }\end{array}$ & $\begin{array}{l}\text { 20. Security Cla } \\
\text { page) } \\
\text { Unclassified }\end{array}$ & & $\begin{array}{l}\text { 21. No. of Pages } \\
71\end{array}$ & 22. Price \\
\hline
\end{tabular}




\section{ACKNOWLEDGEMENTS}

This project was funded by the National Institute for Transportation and Communities (NITC grant number NITC-RR-1240), a U.S. DOT University Transportation Center, and by the Portland Metro regional government.

The authors want to acknowledge the contributions of the graduate research assistants for this project. Huijun Tan contributed to data collection, analysis, and writing portions of the first draft of this report. Nicholas Puczkowskyj contributed to data collection and GIS analysis.

\section{DISCLAIMER}

The contents of this report reflect the views of the authors, who are solely responsible for the facts and the accuracy of the material and information presented herein. This document is disseminated under the sponsorship of the U.S. Department of Transportation University Transportation Centers Program and other participating agencies in the pooled fund project in the interest of information exchange. The U.S. Government and other participating agencies in the pooled fund assumes no liability for the contents or use thereof. The contents do not necessarily reflect the official views of the U.S. Government participating agencies in the pooled fund. This report does not constitute a standard, specification, or regulation.

\section{RECOMMENDED CITATION}

N. McNeil, J. Dill. Revisiting TODs: How Subsequent Development Affects the Travel Behavior of Residents in Existing Transit-Oriented Developments. NITC-RR-1240. Portland, OR: Transportation Research and Education Center (TREC), May, 2020. 


\section{Contents}

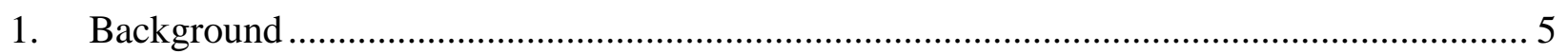

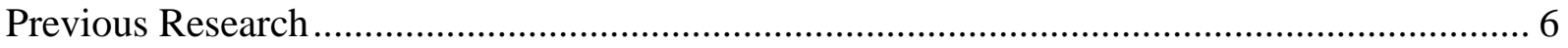

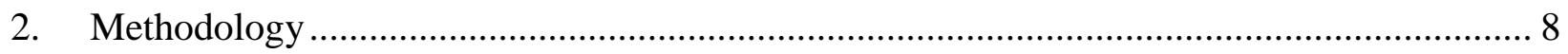

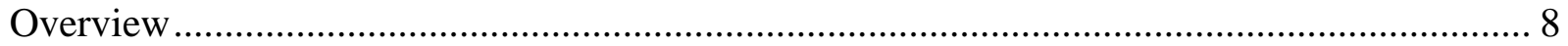

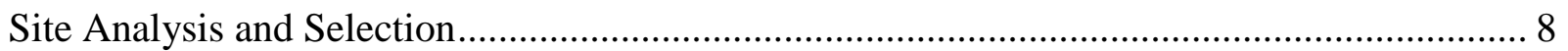

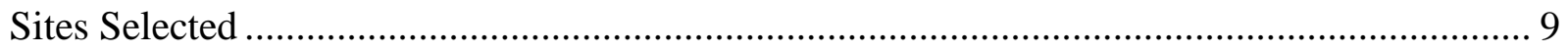

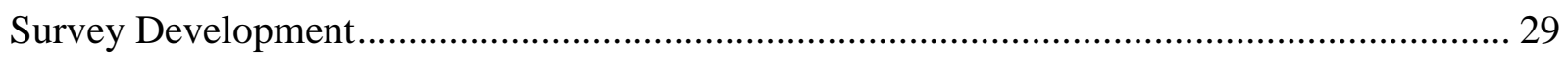

Survey Implementation ..................................................................................................... 31

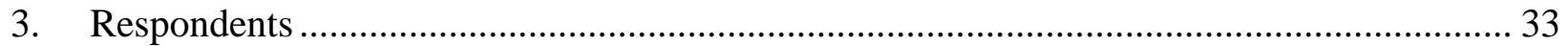

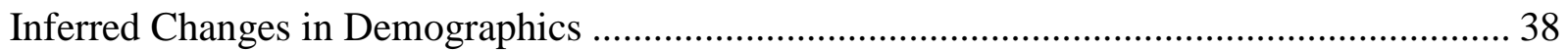

4. Overall Findings on Travel Behavior and Attitudes .............................................................. 39

Transportation Options …………………………………............................................... 39

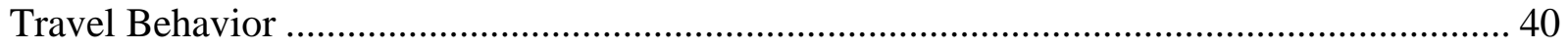

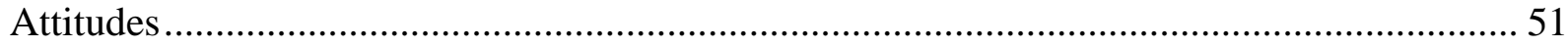

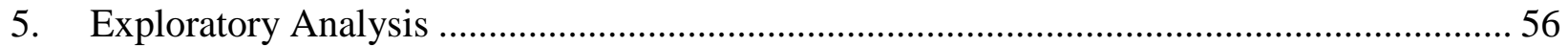

Neighborhood Change and Travel Behavior ........................................................................... 56

Other Factors Associated with Travel Behavior Change........................................................... 58

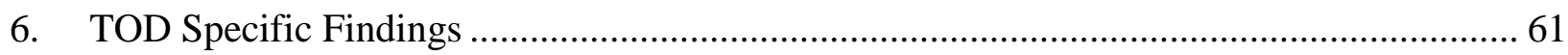

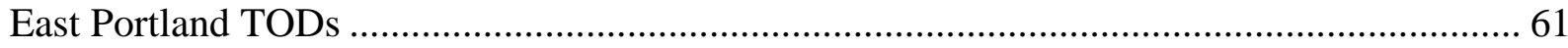

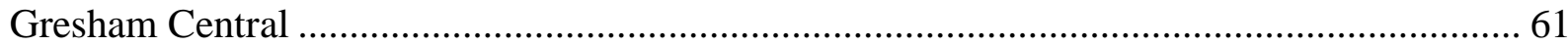

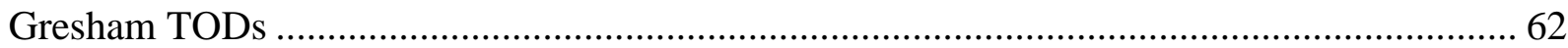

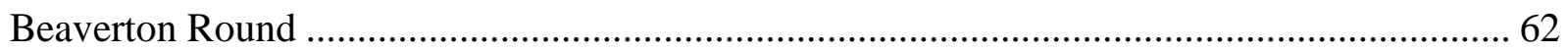

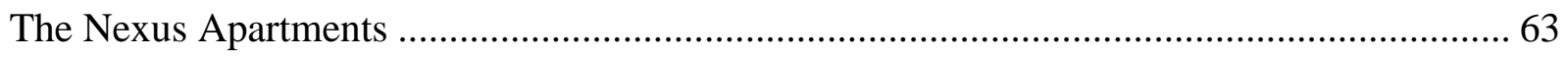

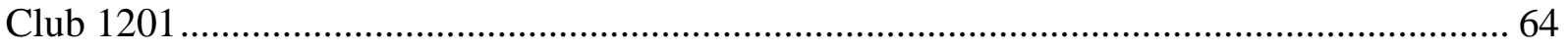

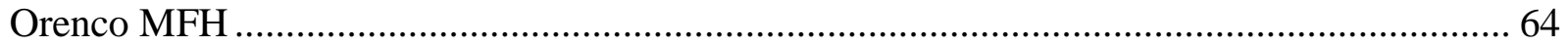

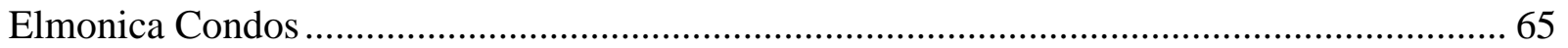

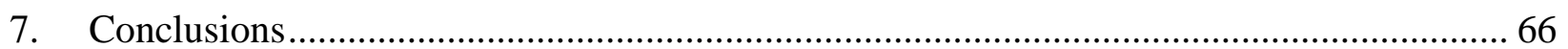

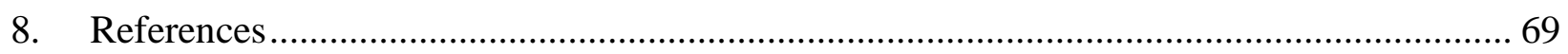

9. Appendix - Second-wave survey instrument ………...................................................... 71 


\section{Background}

Transit-oriented development (TOD) seeks to create a symbiotic relationship between two significant infrastructure investments, public transportation and residential and/or commercial buildings, which can help both to maximize their potential. Dense mixed-use buildings provide potential ridership for transit, while proximity to quality transit provides building residents, employees and visitors with improved access to jobs, services and recreation. However, other factors pertaining to the urban environment around the station and TOD building affect the likely success of both of these TOD elements. A greater density of residents and jobs nearby can better support more services and higher transit frequency. Safer and more connected streets, along with attractive destinations, can promote walking and bicycling trips within the neighborhood and support low-car lifestyles, which can further strengthen the connections between people living and working in the TOD buildings and the transit system.

Since 2000, Metro, the regional government in Portland, OR, has invested public funds in development projects through their TOD program. The agency generally provides between $\$ 300,000$ and $\$ 500,000$ in situations wherein the additional funding can help realize denser projects that increase the number of people served by high-quality transit and/or catalyze development sooner than would occur if left completely to the market. As will be discussed later, definitions of transit-oriented development, and when exactly the term should be applied sometimes differ.

In many cases, the buildings that have received Metro's TOD funding were trail blazers in terms of being among the first multiuse, higher-density buildings or developments in the immediate vicinity of a light rail station or high-frequency bus corridor. In subsequent years, many of those neighborhoods continue to develop with more density and mixed land uses, as well as supportive infrastructure such as bike lanes, new pedestrian connections, or additional transit service.

Portland State University has worked with the Portland Metro regional government periodically since 2005 to survey occupants of buildings for which developers had received funding from Metro's Transit-Oriented Development (TOD) Program. The TOD program, which has a stated goal of funding projects that "stimulate private development of higher-density and mixed-use projects near transit," engaged PSU to better understand actual transit use, among other factors, of residents in these buildings. In many cases, buildings receiving TOD funding are in neighborhoods undergoing transitions, often through the addition of a light rail line and with updated zoning that encourages dense mixed-use development. Most of the surveys were deployed within a year or two of a building opening. Residents' patterns may change over time, and, as these transit-adjacent areas mature into denser, mixed-use neighborhoods, the cumulative effect of changes to land use and available travel options may influence travel decisions and behavior. These changes happen more dramatically in some places than in others, and the breadth of surveyed TOD buildings in prior rounds of surveys (between 2005 and 2014) means that some locations have undergone significant change while others have not. 
This research extends upon the prior TOD surveys in Portland by revisiting a set of developments with a second wave of surveys to understand how the travel behavior of TOD residents may change over time. Key research questions include:

- How does the travel behavior of TOD residents change over time? Does this vary by trip purpose, particularly commuting vs. other purposes?

- If behavior does change, what factors contribute to that change? In particular, as neighborhoods are built out, are TOD residents more likely to use transit (along with walking and bicycling) for travel over car trips?

\section{Previous Research}

The goal of Metro's TOD Program is to strategically invest in projects that "help more people to live, work and shop in neighborhoods served by high-quality transit” (Metro, 2018). A definition from the California Department of Transportation described TOD as "moderate to higher-density development, located within an easy walk of a major transit stop, generally with a mix of residential, employment and shopping opportunities” (Lund et al., 2004). Some efforts have been undertaken to specifically distinguish between transit-oriented development, and similar but less transit friendly developments, which may be in areas that are less dense areas with less land use diversity and less walkable design, termed "transit adjacent development" or TADs (Renne and Ewing, 2013). Taking into account these different definitions, Renne and Ewing found that TODs had higher rates of transit and active transportation commuting, and lower car ownership (Renne and Ewing, 2013). Although more typically featured near rail transit stops, TOD can also occur near high-frequency bus service stops.

Although some early efforts occurred prior to the 1990s, that decade and the early 2000s saw a more sustained push to build TODs. Reasons include changing demographics (such as more childless couples, empty nesters, and immigrants); receptive policy environments interested in livable communities and smart growth; and as a response to worsening traffic congestion (Cervero et al., 2002). As the number of TODs built grew in the 1990s and 2000s, so too did our understanding of how they influence travel behavior. A major study of California TODs in 2003 found that TOD residents were nearly five times as likely to take transit (and considerably less likely to drive) as residents living in the nearby community, with around a quarter of residents commuting by transit (Lund et al., 2004). These findings are consistent with other research that has shown that access to transit increases transit use (e.g., Ewing and Cervero, 2010; Park et al., 2018). The same study found that transit was much less common for non-work trips. For both work and non-work trips, the numbers varied considerably by specific TOD and location, with other factors such as workplace parking, employer policies around flex-time and transit passes, along with land-use variables, seemingly accounting for many of the differences.

The California study was the only study we identified that conducted surveys of residents of the same buildings at different points in time, looking at California suburban TODs in the period from 1993 to 1995 and again in 2003. They found that residents who lived in the buildings the longest were most likely to use transit, and hypothesized that those residents may have remained in part due to their taking advantage of their proximity to transit (Lund et al., 2004). However, while the study examined overall travel and commute differences between the 1990s survey period and the 2003 survey period, they did not examine land-use or transportation changes during the intervening years. We did not identify any other research using the TRID database focusing specifically on housing tenure or how long the TOD building has been in place. 
Our research team has conducted surveys of TODs in the Portland region in 2005, 2007, 2010 and 2014. All but a handful of the TODs we surveyed were part of the Metro TOD program. Findings from the 2005 surveys of commute mode share for transit ( 26\%) and driving ( 58\%) were very similar to the findings in the 2003 California Study (Dill, 2008). Subsequent survey rounds found similar commute rates, including in 2007 - 25\% by transit four to five days per week, $67 \%$ by driving (Dill, 2007); in 2010 - 30\% by transit and $64 \%$ by car (Dill, 2011), and 2014 - 36\% transit, 46\% by car (Dill and McNeil, 2015). However, various factors emerged as important in commute mode choices, including the availability of free parking (more likely to drive), building type (apartment residents were more likely to take transit than townhome residents), type of housing (students, aging-populations), and vehicle availability. Other factors including proximity to the city center appeared to influence travel behavior. In addition, transit use was more common for commuting vs. other trip purposes, which is consistent with other TOD research.

Studies of travel and built environment suggest that a range of built environment characteristics are likely to affect travel in some way, though many focus on vehicle miles travelled rather than transit trips (or miles). One meta-analysis found that destination accessibility (particularly job accessibility and distance to downtown) were most associated with decreased VMT, followed by design factors (e.g., intersection density) and land-use mix (Ewing and Cervero, 2010).

Different types of TODs can have various effects on travel behavior. Some studies classified the TODs according to the existing TODs characteristics, such as walkability (Schlossberg, 2004); public transportation node (e.g., number of reachable railway stations in 20 minutes) (Zemp et al., 2011); and overlay zoning ordinance (Atkinson-Palombo and Kuby, 2011). Some scholars classified TODs based on the evolution of cities (Cervero, 1998), or the initial stage of development (De Vos et al., 2014). The geographic variation is also identified for TOD strategic planning such as downtown, urban neighborhood, main street, suburban town center, suburban neighborhood, commuter town center, etc. (Dittmar and Poticha, 2004).

Some research has also investigated the factors affecting transit demand. Canepa (2007) reviews that transit connection (e.g., bus connectivity); parking situation in TODs (e.g., availability of feeder bus service, employer parking); housing density (or residential density); employment concentration; the density of retail employment; and regional connectivity (e.g., regional transit network surrounding area's jobs-to-housing ratio) are factors associated with the transit usage and walkability in TODs. Foth et al. (2014) examined mode share change over time associated with accessibility to different job categories and found that workers in some job categories are more likely than others to commute by transit if accessibility increased by improved transit networks. 


\section{Methodology}

\section{Overview}

To answer the research questions, we conducted surveys at TODs that we had previously surveyed. Key tasks in the project included identifying which TODs would be surveyed in a second wave in 2018 and 2019 (also referred to as “wave 2" surveys), developing a composite survey instrument from prior years' surveys, carrying out the surveys, and analyzing survey data to understand if travel behavior had changed.

Prior to selecting locations for the second-wave survey, we sought to identify how the neighborhoods around the buildings had changed over time and select a set of locations that had experienced different levels and types of change. This included looking at geographic and census data, a visual review of aerial imagery, and segmenting the locations by area within the Portland region. The baseline survey date was also considered, with a strong preference for sites that had been surveyed in the earlier survey rounds (e.g., 2005 and 2007). Developing the survey instrument involved examining past instruments (which had changed slightly over the years), and mapping key questions that remained consistent, along with which questions that had changed should still be included.

\section{Site Analysis and Selection}

\section{GIS Data}

For each development, the project team sought to collect site-related information for both the survey year (when possible) and for 2018 (Table 2-1). Most of the GIS data on land-use and transportation characteristics came from the Portland Metro Regional Land Information System (RLIS), including the RLIS archive going back to 1996. The U.S. Census was used for population data, while the Census' Longitudinal Employer-Household Dynamics (LODES) data was used to estimate employment in the vicinity of developments.

Using street layers and Network Analyst (ArcGIS), we created a quarter-mile network buffer around each building using the current (2018) street network and the street network from the time of the baseline survey. These buffers were used to inform and calculate many of the subsequent variables. 
Table 2-1 GIS Variables

\begin{tabular}{|c|c|c|}
\hline Variable & Description & Data Source \\
\hline Buffer Area & Quarter-mile buffer around building address & RLIS \\
\hline Population & $\begin{array}{l}\text { sum of population in block groups (by proportion of block } \\
\text { group area contained within buffer) }\end{array}$ & U.S. Census \\
\hline Population Density & population in block groups per sq. mi. in buffer & U.S. Census \\
\hline Intersections & \# of intersections in buffer & RLIS \\
\hline Intersection Density & \# of intersections per sq. mi. in buffer & RLIS \\
\hline Jobs & $\begin{array}{l}\text { sum of jobs in block groups (by proportion of block group area } \\
\text { contained within buffer) }\end{array}$ & $\begin{array}{l}\text { U.S. Census } \\
\text { (LODES) }\end{array}$ \\
\hline Job Density & jobs in block groups per sq. mi. in buffer & $\begin{array}{l}\text { U.S. Census } \\
\text { (LODES) }\end{array}$ \\
\hline Light Rail & \# of light rail lines accessible & RLIS \\
\hline Bus Routes & \# of bus routes accessible & RLIS \\
\hline Bus Stops & \# of bus stops accessible & RLIS \\
\hline Bike Miles & miles of bike routes & RLIS \\
\hline
\end{tabular}

\section{Historical Aerial / Satellite Data through Google Earth}

To conduct a visual assessment of development change over time, the project team used Google Earth historical satellite imagery from periods as close to the baseline survey data as possible for each building. The images were compared to satellite images from 2018 to identify significant changes such as new buildings, parks and other facilities such as sidewalks.

\section{Segmentation by Geography and Time}

With the GIS data and satellite imagery, the project team selected sites using several criteria:

- A range of sites with respect to neighborhood change - sites with little change, sites with significant land-use change, and sites with changes to transportation infrastructure or service.

- Some geographic spread, including sites near MAX light rail stations in the western suburbs, in the eastern suburbs, and in areas outside of the city center.

- Sites that were originally surveyed in 2010 or earlier so that enough time could have passed to allow for neighborhood change.

- Some consistency in types of housing. The baseline surveys included some higherdensity (than typical), single-family detached homes, as well as duplexes and triplexes. These were not included.

\section{Sites Selected}

\section{Overview}

The selected TODs (Table 2-2) are briefly described here, followed by satellite images at the time of the baseline survey and 2018. The following section shows the measured changes around the sites. 
Table 2-2: TOD Sites Selected

\begin{tabular}{|c|c|c|c|c|c|c|c|c|}
\hline Building Name & $\begin{array}{l}\text { Survey } \\
\text { Year }\end{array}$ & $\begin{array}{l}\text { Constr. } \\
\text { Year }\end{array}$ & $\begin{array}{l}\# \\
\text { Units }\end{array}$ & $\begin{array}{l}\text { Building } \\
\text { Type }\end{array}$ & $\begin{array}{l}\text { Developer \& } \\
\text { Architecture }\end{array}$ & $\begin{array}{l}\text { Site Sq. } \\
\text { Ft. }\end{array}$ & $\begin{array}{l}\text { Comm. } \\
\text { Sq. Ft. }\end{array}$ & Station \\
\hline Nexus & 2010 & 2007 & 422 & Apartment & $\begin{array}{l}\text { Simpson Housing / } \\
\text { Hensley Lamkin } \\
\text { Rachel, Inc. }\end{array}$ & 561,924 & 7,100 & \multirow{3}{*}{$\begin{array}{l}\text { Orenco/NW } \\
\text { 231st Ave, } \\
\text { Hillsboro }\end{array}$} \\
\hline Club 1201* & 2005 & 2000 & 210 & Townhomes & $\begin{array}{l}\text { Simpson Housing / } \\
\text { McDonald Environment } \\
\text { Planning, PC }\end{array}$ & 516,211 & 0 & \\
\hline $\begin{array}{l}\text { Orenco Station- } \\
\text { MFH* }^{*}\end{array}$ & 2005 & $\begin{array}{l}1997- \\
2003\end{array}$ & 114 & Mixed & & 94,311 & 0 & \\
\hline $\begin{array}{l}\text { Elmonica Station } \\
\text { Condominiums* }\end{array}$ & 2005 & $\begin{array}{l}2004- \\
2005\end{array}$ & 120 & Condo & $\begin{array}{l}\text { Simpson Housing / } \\
\text { Merryman Barnes } \\
\text { Architects }\end{array}$ & 147,794 & 0 & $\begin{array}{l}\text { Elmonica } \\
\text { MAX } \\
\text { Station }\end{array}$ \\
\hline $\begin{array}{l}\text { Beaverton } \\
\text { Round* }\end{array}$ & 2005 & 2003 & 63 & $\begin{array}{l}\text { Condo/ } \\
\text { Mixed }\end{array}$ & City / BCB Group & 46,380 & & $\begin{array}{l}\text { Beaverton } \\
\text { Central } \\
\text { MAX } \\
\text { Station }\end{array}$ \\
\hline $\begin{array}{l}\text { Broadway } \\
\text { Vantage }\end{array}$ & 2010 & 2009 & 58 & Apartment & $\begin{array}{l}\text { Innovative Housing Inc. } \\
\text { / LRS Architects }\end{array}$ & 50,520 & 2,670 & $\begin{array}{l}\text { NE 82nd } \\
\text { Ave., } \\
\text { Portland }\end{array}$ \\
\hline Center Commons & 2007 & 2001 & 39 & Apartment & $\begin{array}{l}\text { Lenar Affordable } \\
\text { Housing / Vallaster } \\
\text { Corl Architects PC and } \\
\text { OTAK }\end{array}$ & 142,622 & 1,500 & $\begin{array}{l}\text { NE 60th } \\
\text { Ave., } \\
\text { Portland }\end{array}$ \\
\hline $\begin{array}{l}\text { Center Commons } \\
\text { Townhomes }\end{array}$ & 2007 & 2001 & 26 & Townhomes & $\begin{array}{l}\text { American Pacific } \\
\text { Properties, Inc. / } \\
\text { Vallaster Corl } \\
\text { Architects PC and } \\
\text { OTAK }\end{array}$ & 33,237 & 0 & $\begin{array}{l}\text { NE 60th } \\
\text { Ave., } \\
\text { Portland }\end{array}$ \\
\hline Bridal Veil & 2007 & 2000 & 8 & Condo & & 12,000 & 0 & \multirow{8}{*}{$\begin{array}{l}\text { Gresham } \\
\text { Central, } \\
\text { Gresham. }\end{array}$} \\
\hline Central Point & 2007 & 2000 & 22 & $\begin{array}{l}\text { Condo/ } \\
\text { Mixed }\end{array}$ & $\begin{array}{l}\text { Peak Development / } \\
\text { Ankrom Moisan } \\
\text { Architects }\end{array}$ & 11,761 & 3,500 & \\
\hline Gresham Central & 2007 & 1996 & 90 & Apartment & & 124,324 & 0 & \\
\hline Landmark & 2007 & 2007 & 29 & Townhomes & & 52,139 & 0 & \\
\hline Oneonta & 2007 & 1995 & 20 & Townhomes & & 51,969 & 0 & \\
\hline Three Cedars & 2007 & 2000 & 16 & Apartment & & 18,615 & 0 & \\
\hline 3rd Central & 2010 & 2009 & 34 & Apt/Mixed & $\begin{array}{l}\text { Tokola Properties / PF } \\
\text { Architecture }\end{array}$ & 28,314 & 5,450 & \\
\hline The Beranger & 2010 & 2006 & 24 & $\begin{array}{l}\text { Condo/ } \\
\text { Mixed }\end{array}$ & $\begin{array}{l}\text { Rossman Development } \\
\text { LLC / Myhre Group } \\
\text { Architects }\end{array}$ & 22,955 & & \\
\hline
\end{tabular}

Note: Sites with an asterisk $\left(^{*}\right)$ were not part of the Metro TOD program.

Westside TODs: Five of the TODs are to the west of downtown Portland in Washington County. We include three developments around the Orenco/NW 231 ${ }^{\text {st }}$ Ave. MAX Station in 
Hillsboro. This includes what we label "Orenco Multifamily Housing” and Club 1201 which were part of first stage of TOD development around that MAX station (Figure 2-1, Figure 2-9, Figure 2-10). The Nexus apartments were built in the next phase of development and are closer to the MAX station (Figure 2-2, Figure 2-11). The Elmonica Station Condominiums (Figure 2-3, Figure 2-12) are similar to Club 1201, in so far as they are a dense townhouse-style development, but differ in that adjacent development has been nearly exclusively residential. Beaverton Round condominiums (Figure 2-3) are directly adjacent to a MAX station. Since construction and the baseline survey, a new municipal office building was built nearby (Figure 2-13).
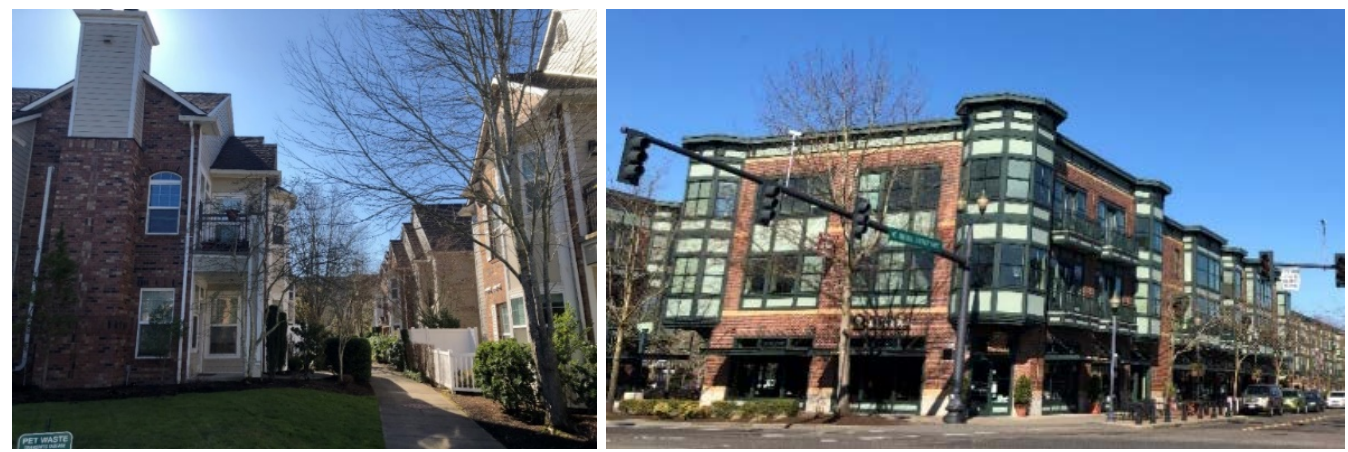

Figure 2-1 Club 1201 (left) and Orenco Station multifamily housing (right)

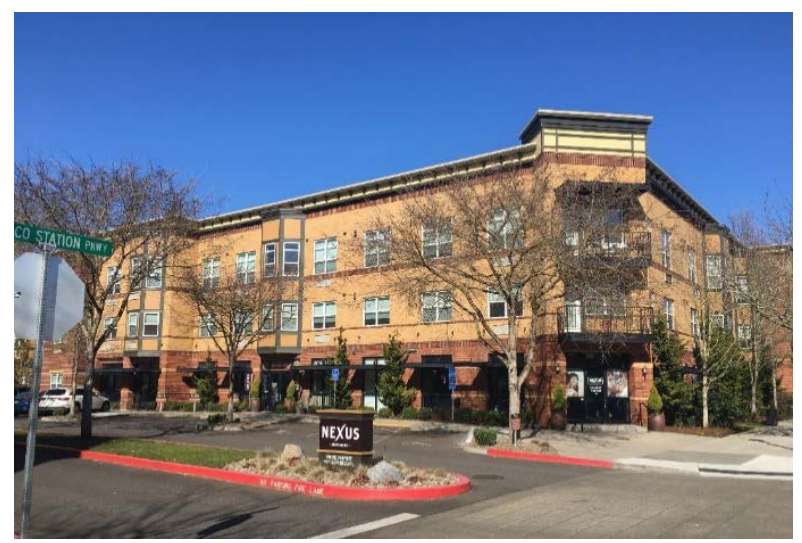

Figure 2-2 Nexus apartments 

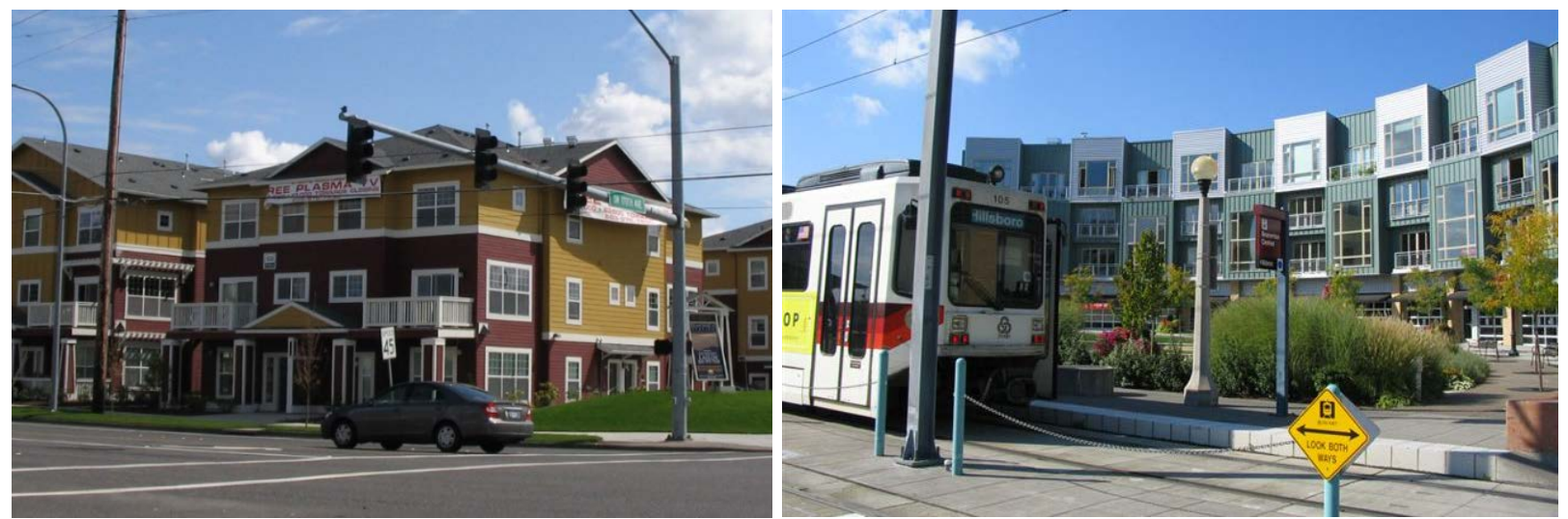

Figure 2-1 Elmonica Station Condominiums (left) and Beaverton Round (right)

East Portland TODs: Two TODs in the eastern part of Portland were selected: Center Commons and Broadway Vantage. Both of these developments are along the Green MAX line, a line that started operations in 2009, after the baseline survey at Center Commons and one year before the baseline survey at Broadway Vantage. The Green line joined the Red and Blue lines in servicing these stations. Center Commons (Figure 2-4, Figure 2-15), located next to the NE $60^{\text {th }}$ Avenue Max station, includes both apartments and townhomes. Broadway Vantage is located near the NE $82^{\text {nd }}$ Avenue MAX station (Figure 2-4, Figure 2-14). In both cases, there was very limited new development in the period between the initial surveys and 2018.
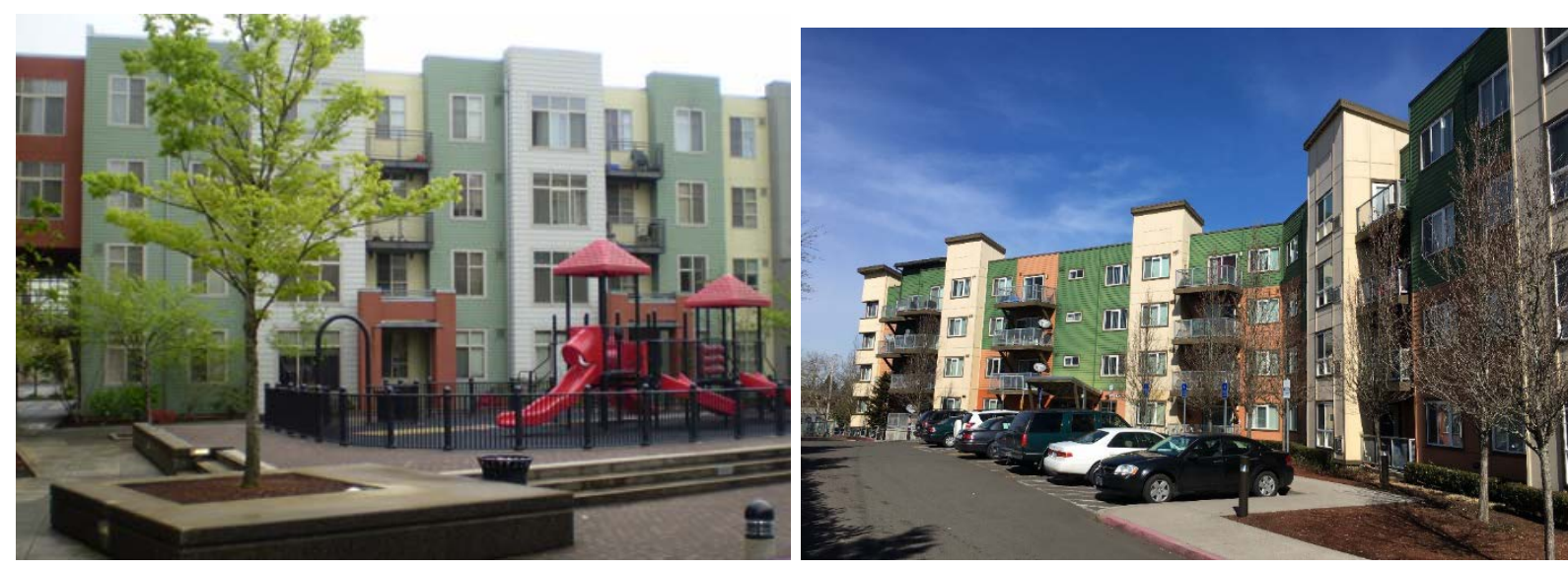

Figure 2-2 Center Commons (left) and Broadway Vantage (right)

Gresham TODs: A total of nine TODs in the east side suburb of Gresham were included in this assessment. All of these TODs are located in downtown Gresham, and mostly within three to four blocks of one another. A group of these TODs were built between 1995 and 2007, and were initially surveyed in 2007. These include Bridal Veil and Central Point (Figure 2-5), Gresham Central and Landmark (Figure 2-6), Oneonta and Three Cedars (Figure 2-7). Since the initial survey, a number of new buildings, parks and sidewalks were completed (Figure 2-16). Several additional Gresham TODs were surveyed in 2010, including 3rd Central and The Beranger (Figure 2-8). Changes since that survey include some new residential construction (Figure 2-17). 
Outside of Gresham Central, most of the Gresham TODs had relatively few units (ranging from 8 to 34), and will be grouped for the purposes of analysis.
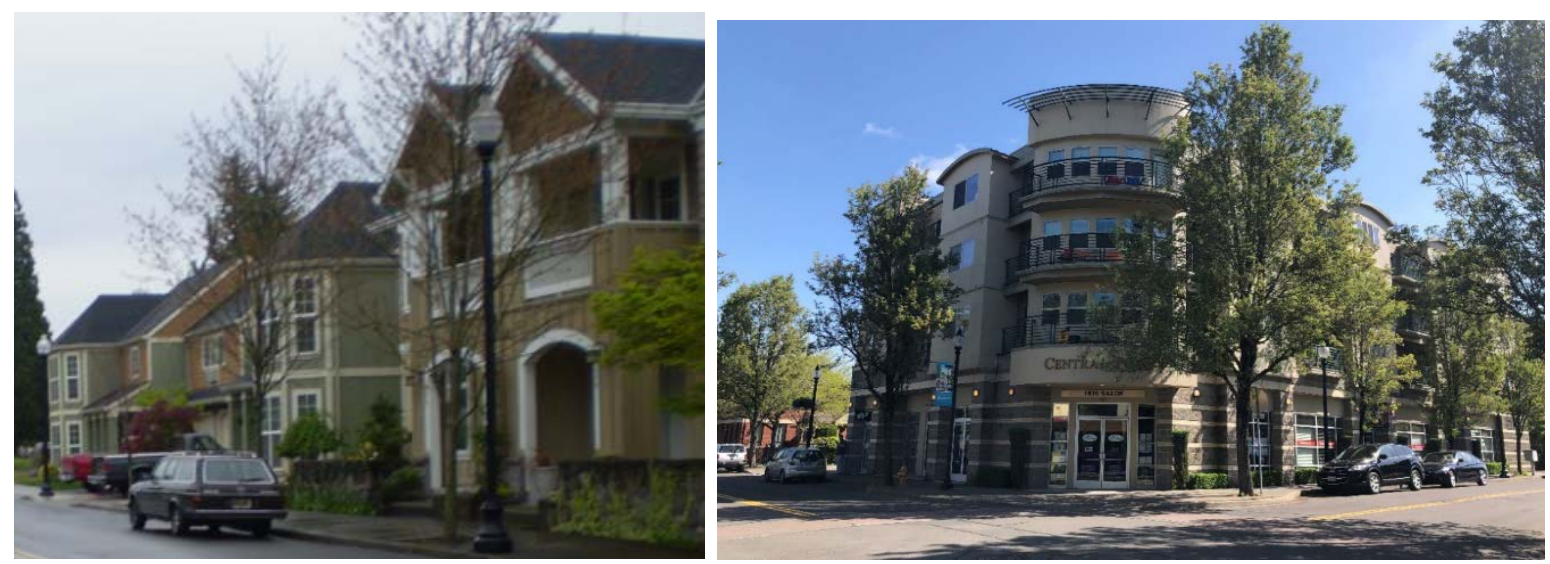

Figure 2-5 Bridal Veil (left) and Central Point (right)
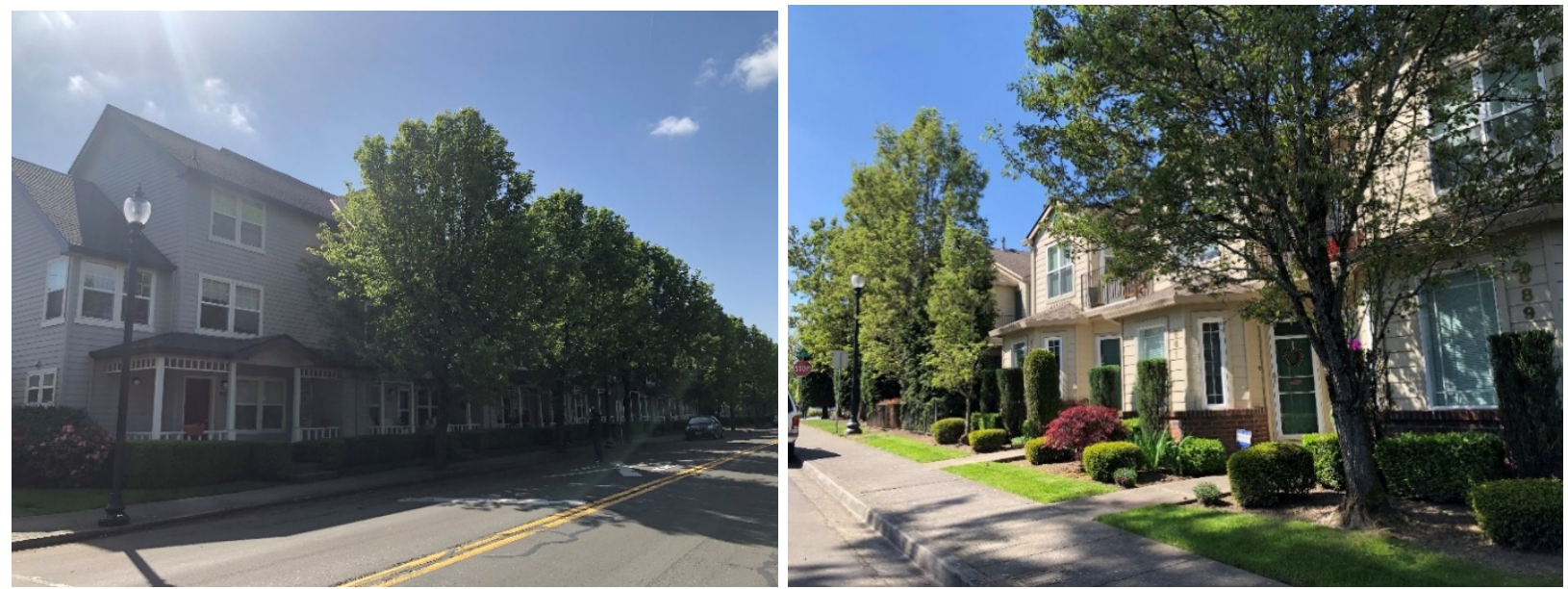

Figure 2-3 Gresham Central (left) and Landmark (right) 

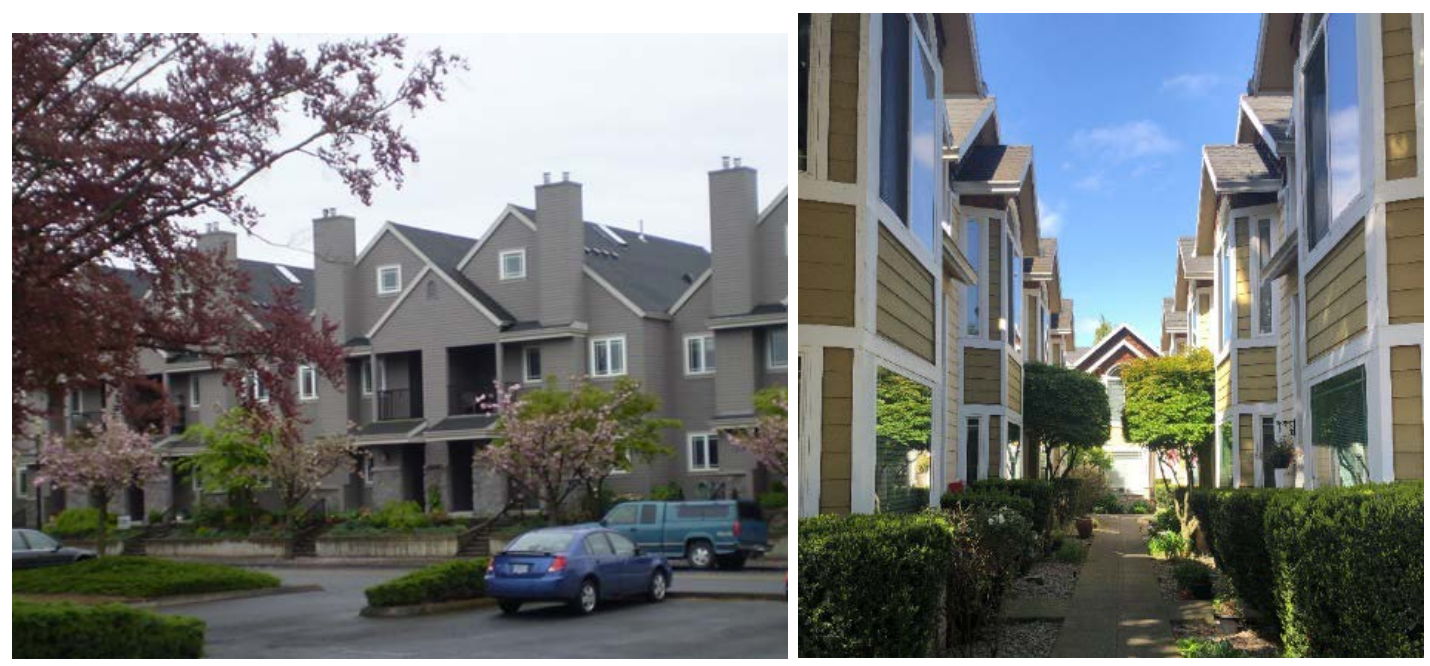

Figure 2-4 Oneonta (left) and Three Cedars (right)
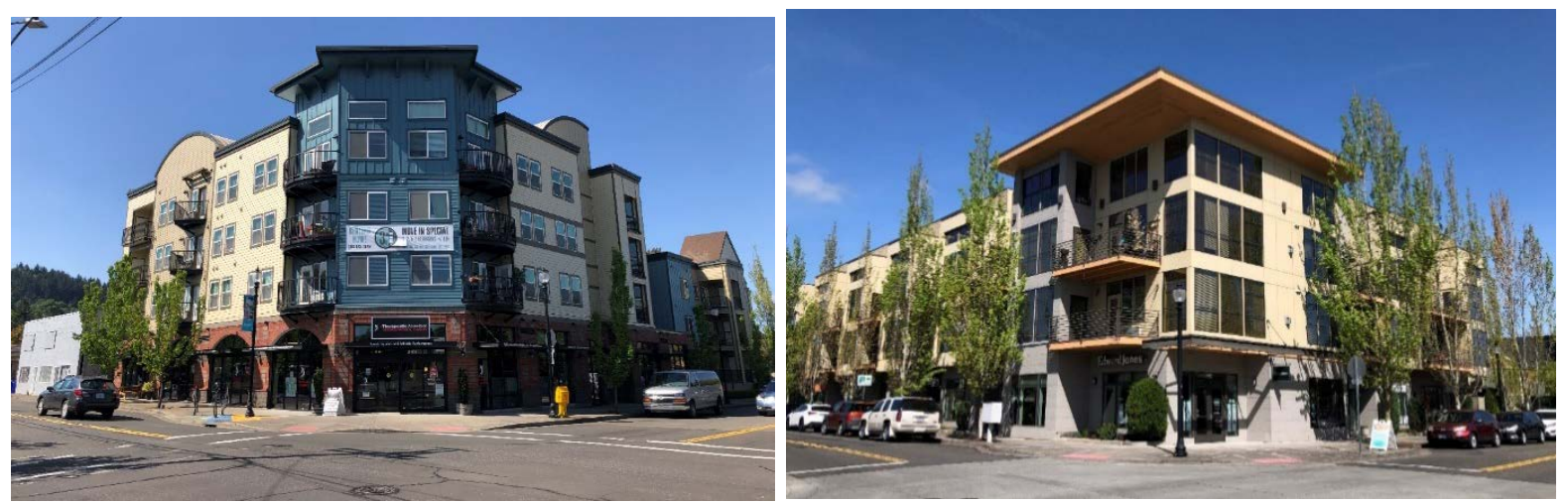

Figure 2-5. $3^{\text {rd }}$ Central (left) and The Beranger (right) 


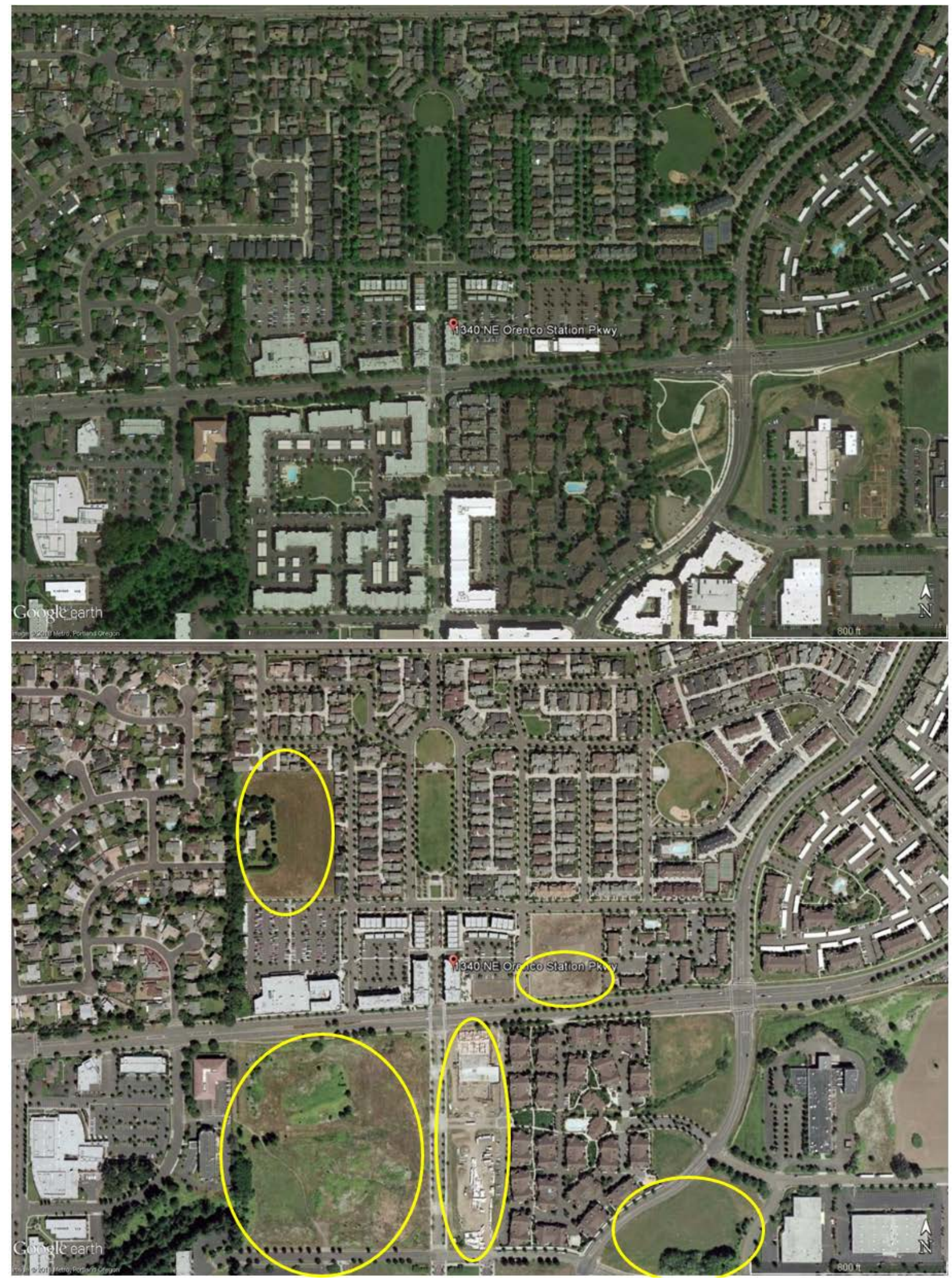

Figure 2-6 Orenco Station multifamily housing, Hillsboro (Top: 2018; Bottom: 2005 - lots circled will be developed) 


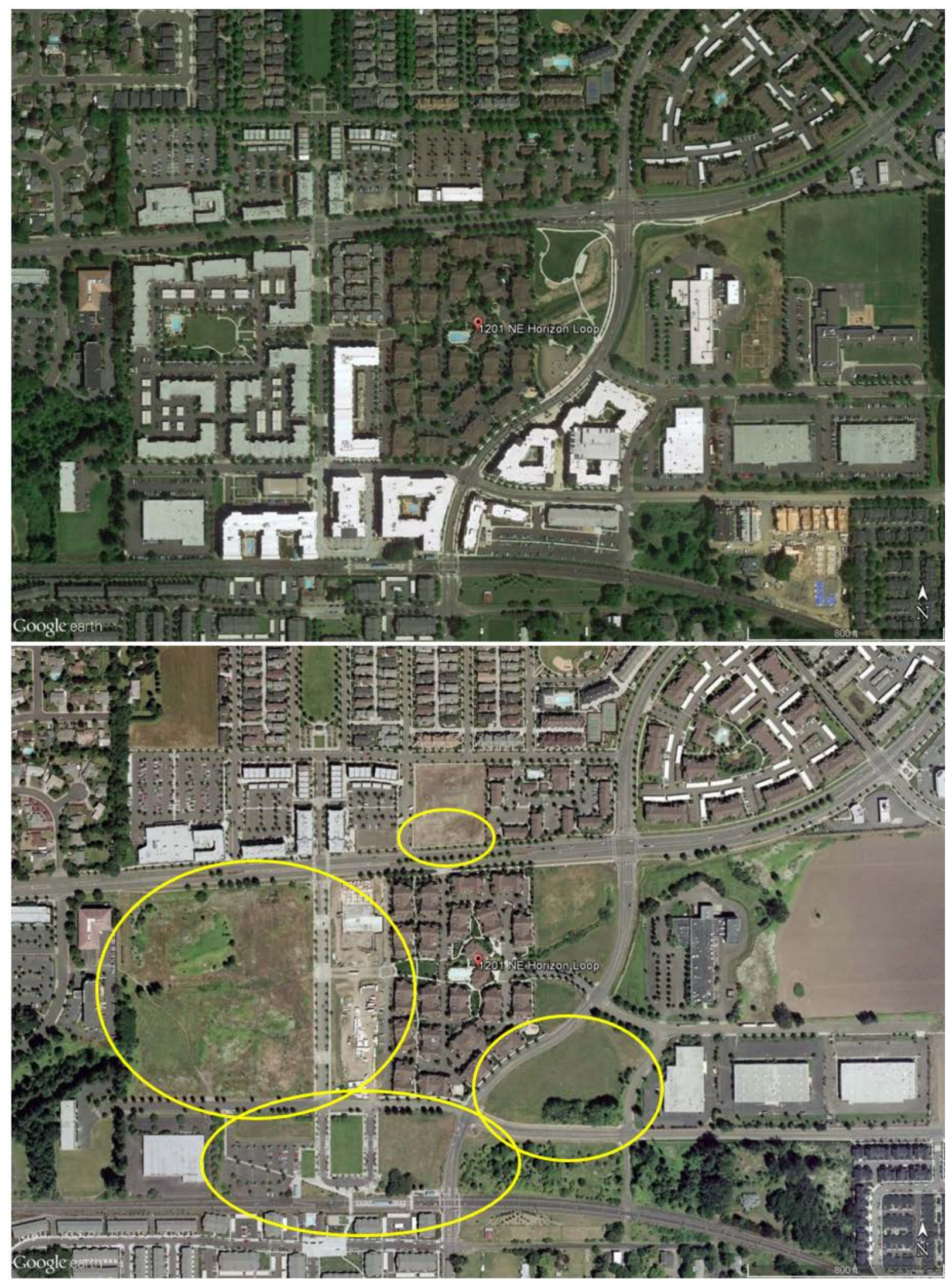

Figure 2-10 Club 1201, Hillsboro (Top: 2018; Bottom: 2005 - lots circled will be developed) 


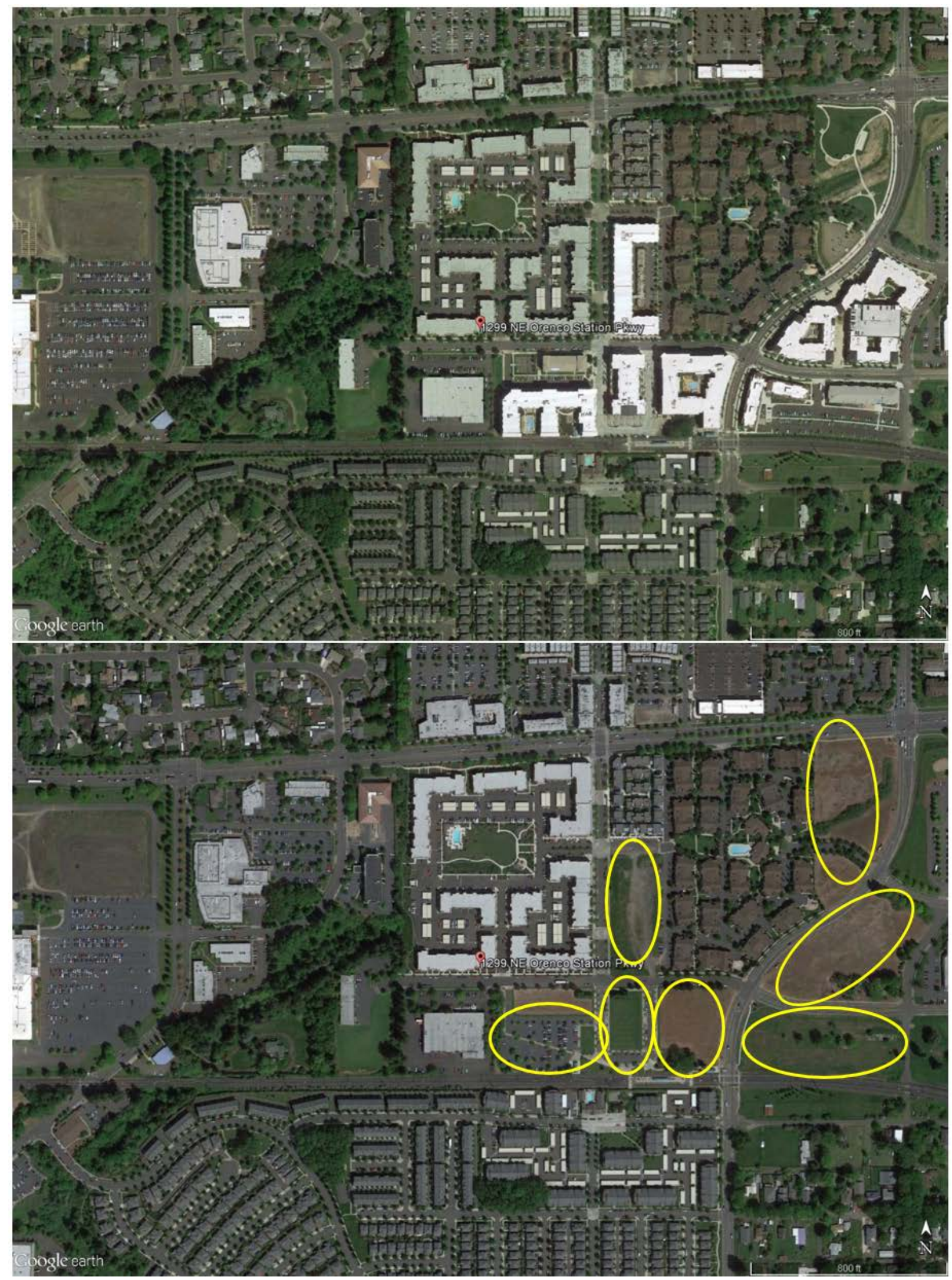

Figure 2-7 Nexus apartments, Hillsboro (Top: 2018; Bottom: 2010 - lots circled will be developed) 


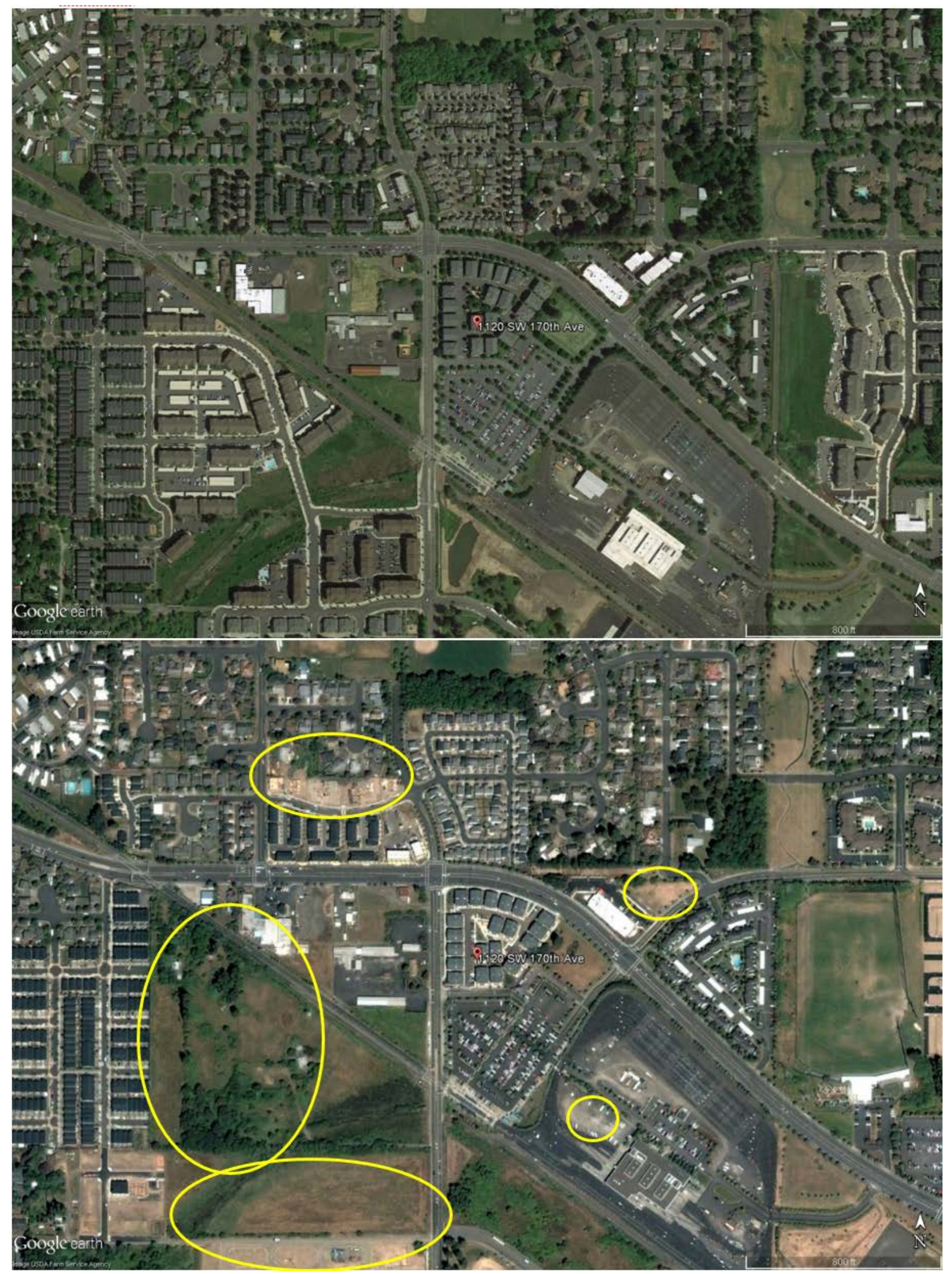

Figure 2-8 Elmonica Condominiums, Hillsboro (Top: 2018; Bottom: 2005 - lots circled will be developed) 


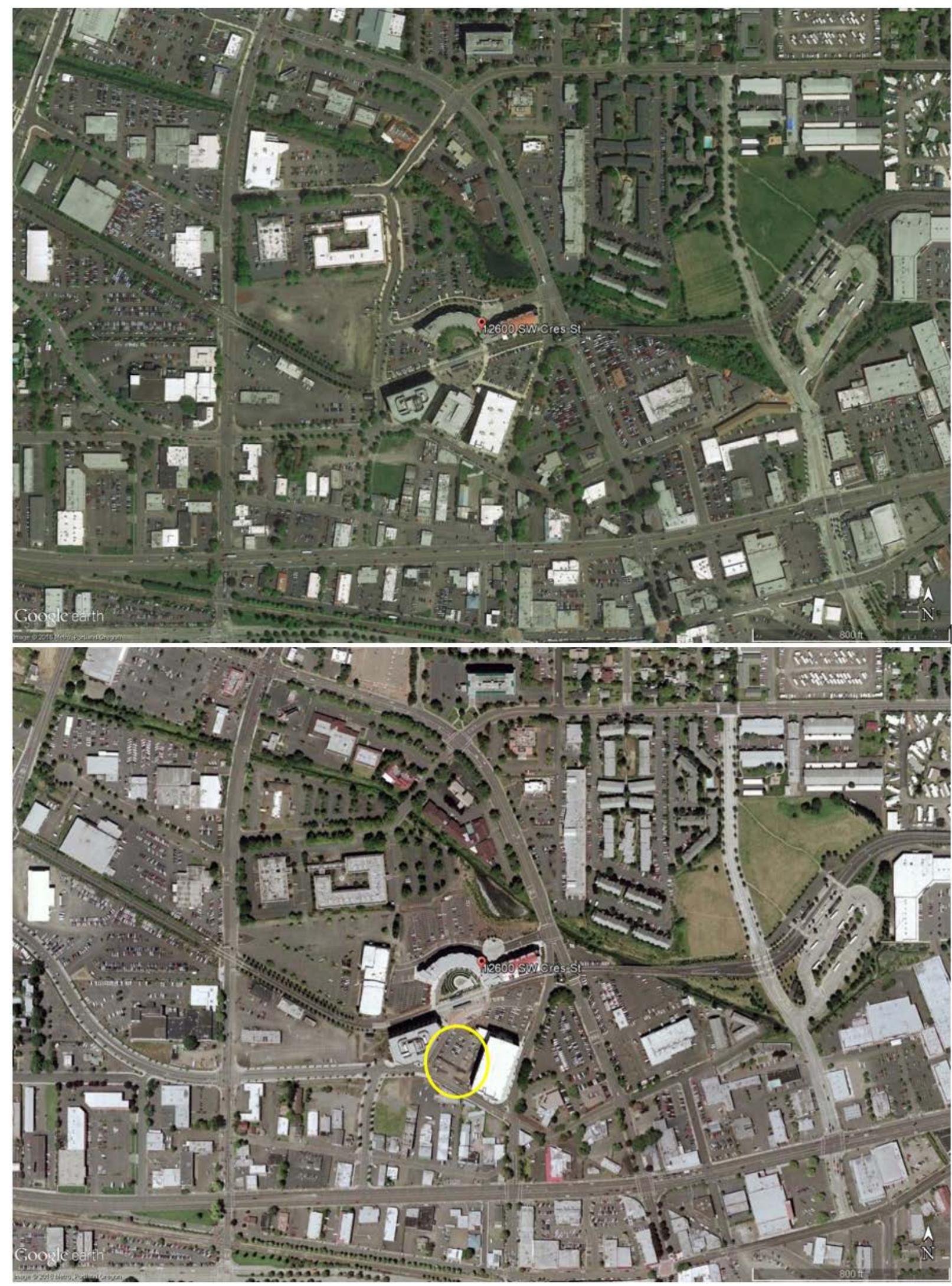

Figure 2-9 Beaverton Round, Beaverton (Top: 2018; Bottom: 2005 - lots circled will be developed) 


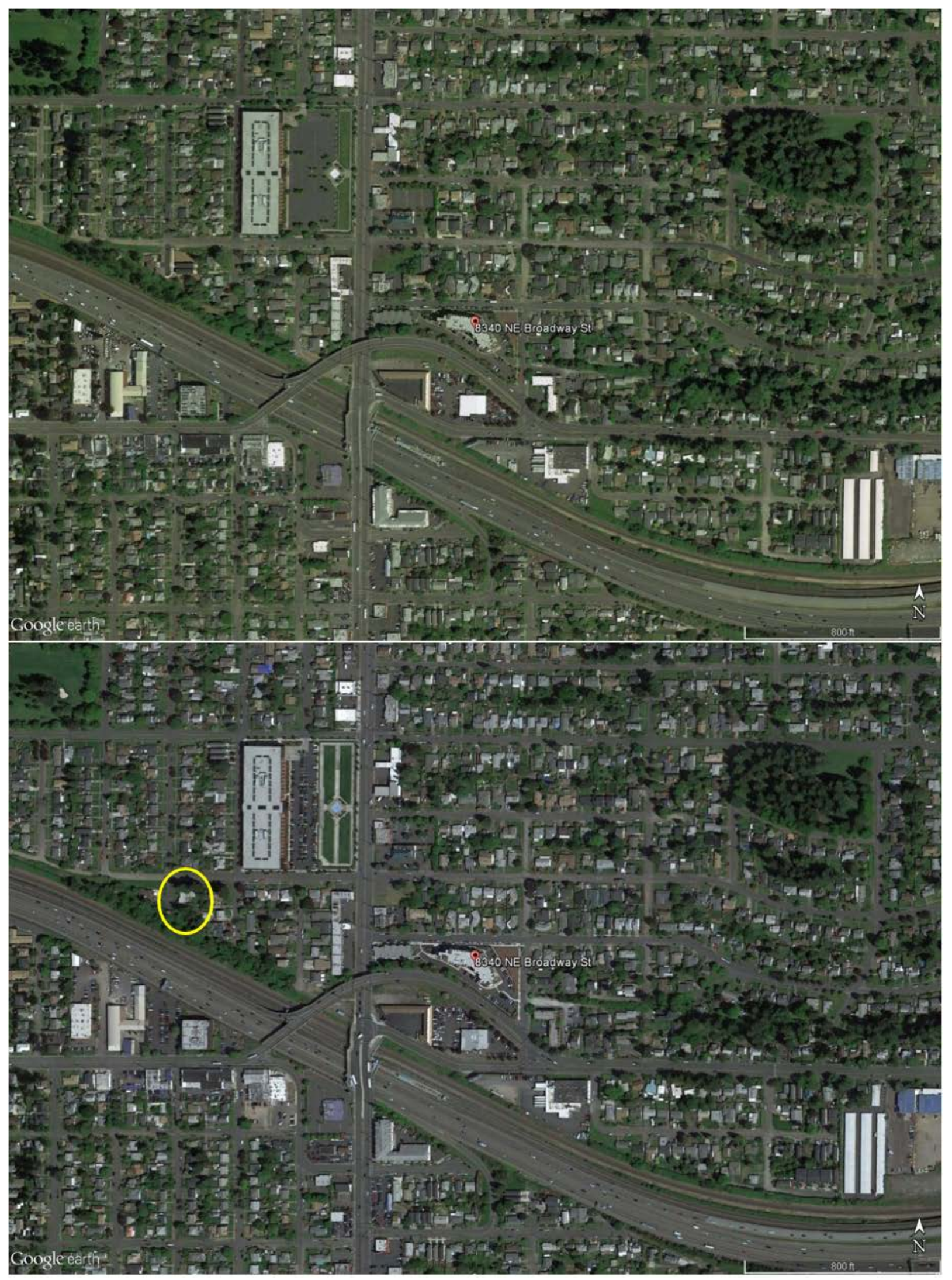

Figure 2-10 Broadway Vantage, Portland (Top: 2018; Bottom: 2010 - lots circled will be developed) 


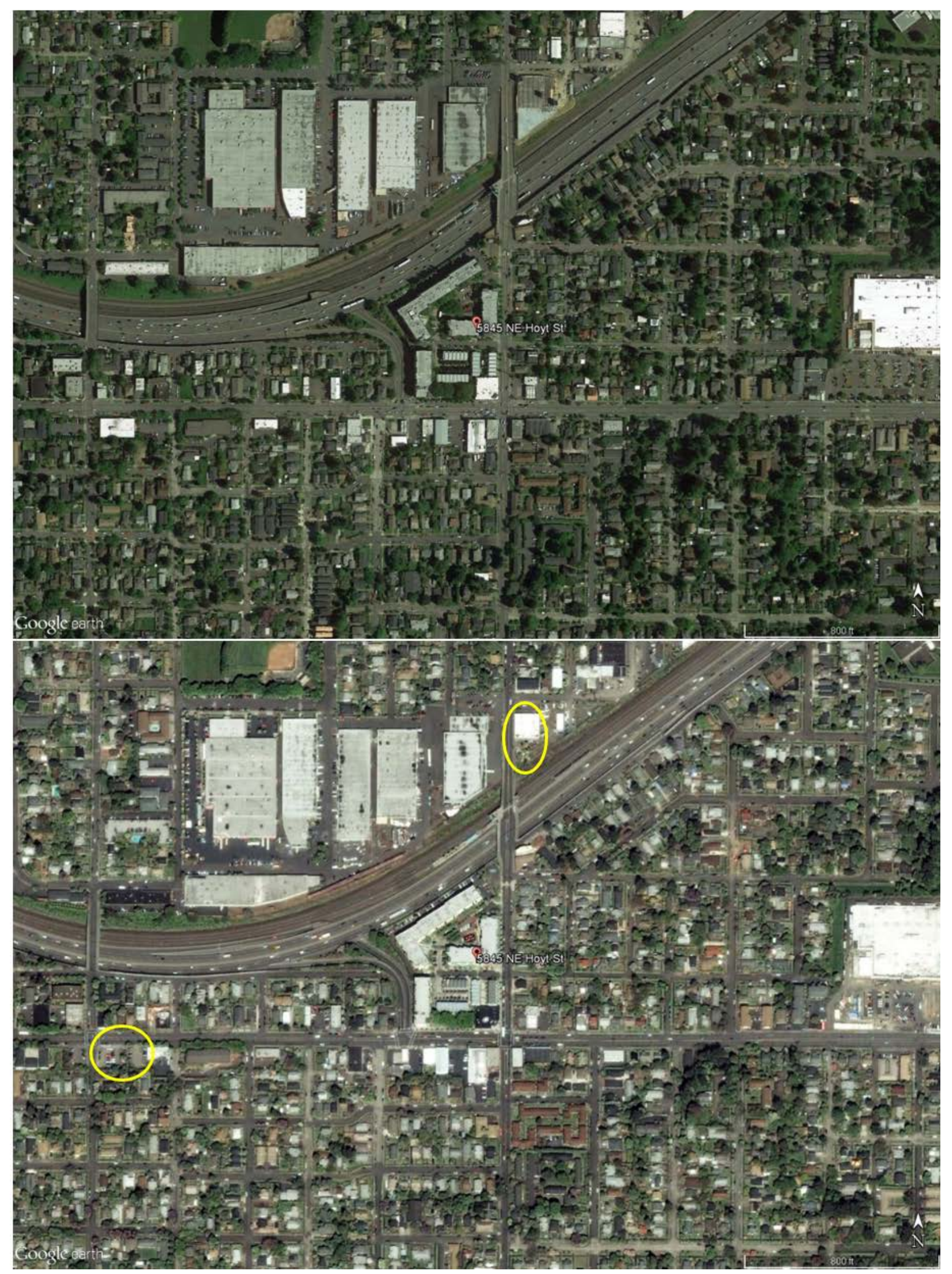

Figure 2-11 Center Common, East Portland (Top: 2018; Bottom: 2007 - lots circled will be developed) 


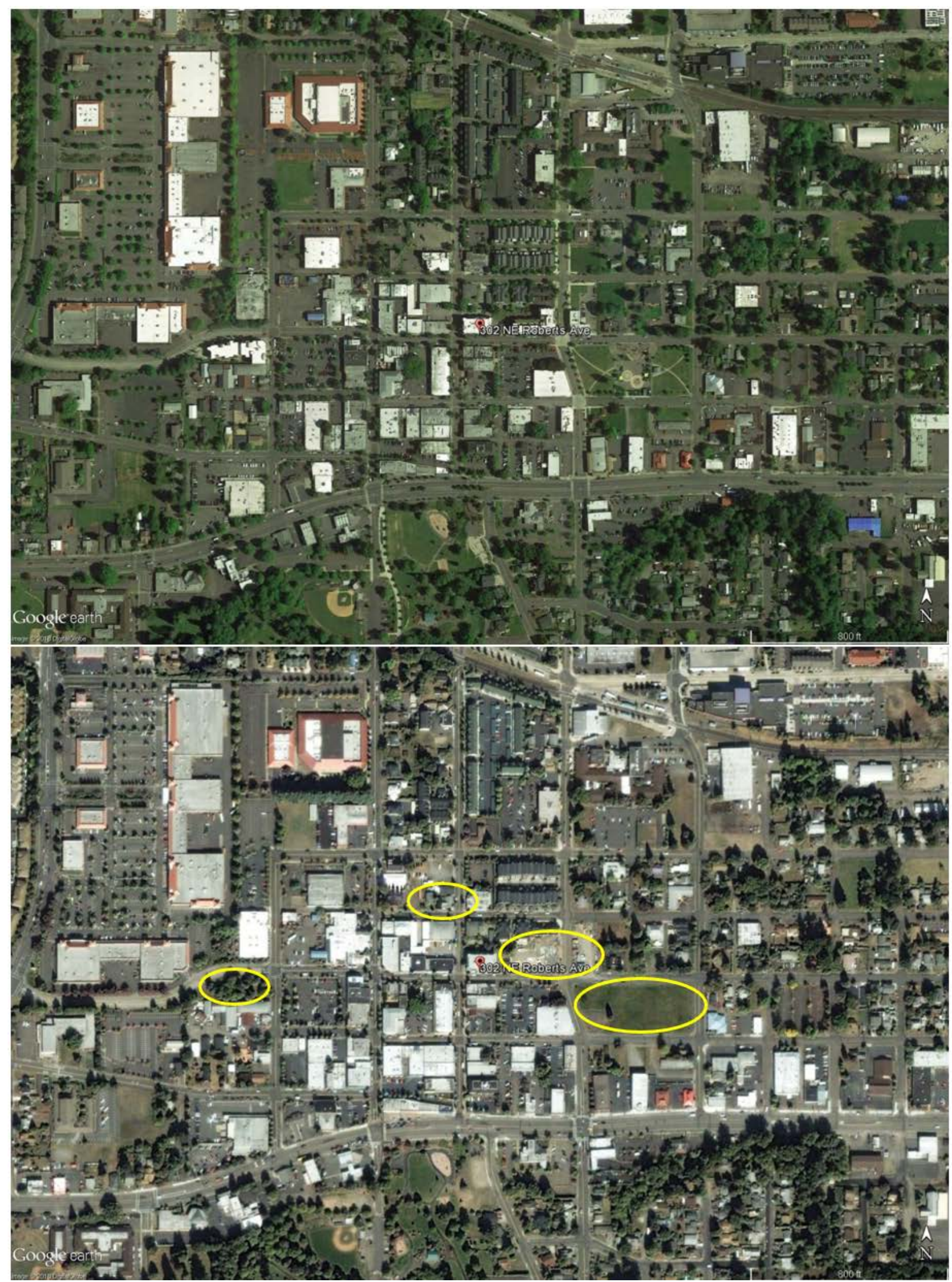

Figure 2-12 Gresham TODs 2007 to 2018 (Top: 2018; Bottom: 2007 - lots circled will be developed) 


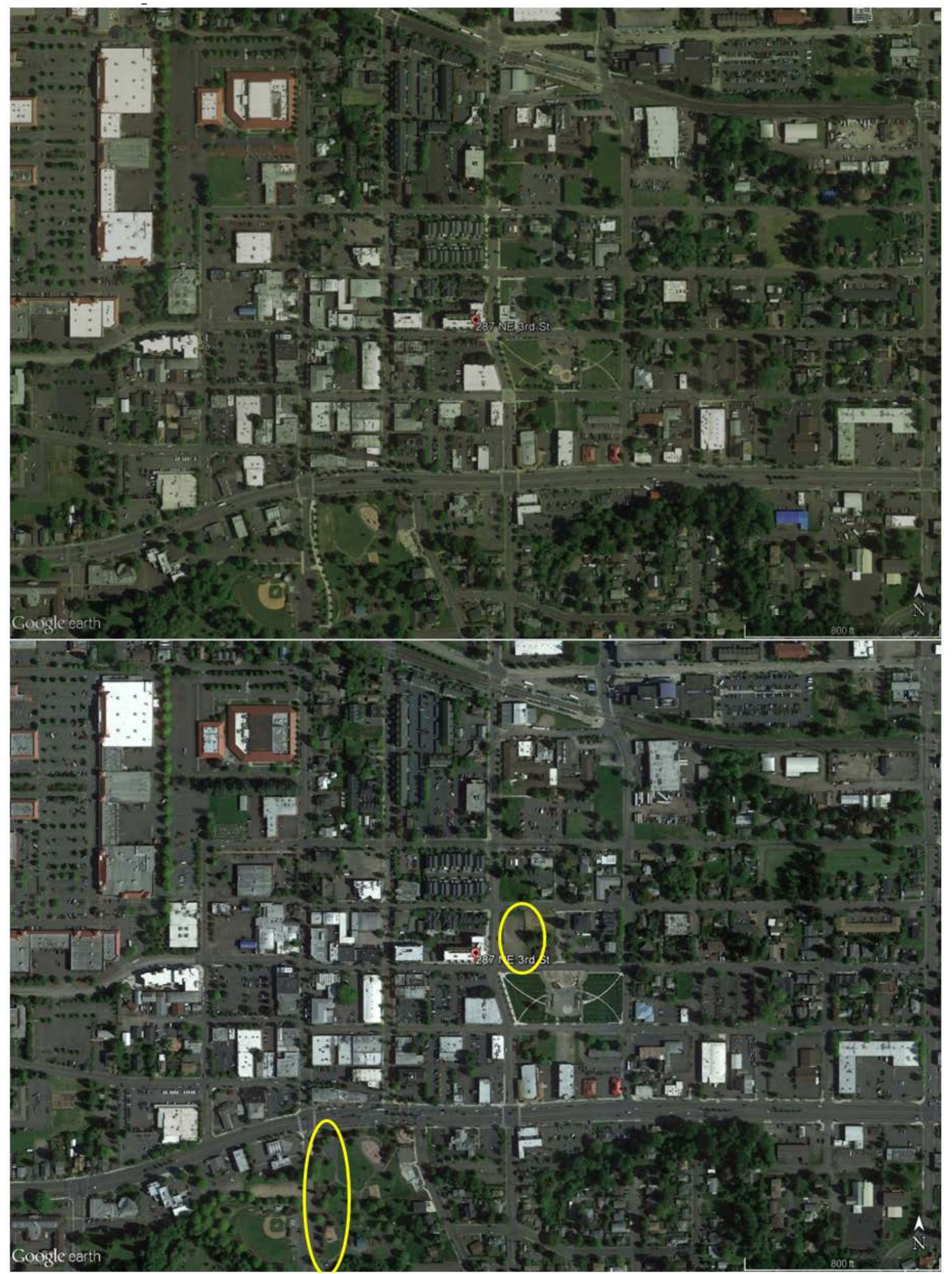

Figure 2-13 Gresham TODs 2010 to 2018 (Top: 2018; Bottom: 2007 - lots circled will be developed) 


\section{TOD Characteristics}

Definitions of TOD vary and have evolved over time. In this research, inclusion of a site as a TOD was primarily based on the development receiving funding from Metro's TOD program, as most of the original surveys were done with research funding from Metro. The purpose of the Metro TOD program is to incentivize development that would accommodate more people closer to high-quality transit than would have occurred without program efforts. As a result, most of the developments have been outside of the central city, often in relatively low-density neighborhoods. The program has also evolved over the years, as has development in the region. Therefore, some of the earliest projects supported through the program in the early 2000s are smaller scale and/or lower density that more recent projects. However, they were supported by Metro because the agency determined that the projects would increase density near transit beyond what would have occurred without the agency's support.

Four of the TODs in this study were not part of the Metro program: Club 1201; Orenco StationMFH; Elmonica Station Condominiums; and Beaverton Round. Those projects were part of a 2005 research project. In our report on that research, we noted that "[t]here is some debate over how to define TODs. Cervero et al (2004) decide not to "parse definitions of TOD" but do state that 'there is agreement within the professional transit community as to what constitutes a TOD: a pattern of dense, diverse, pedestrian-friendly land uses near transit nodes that, under the right conditions, translates into higher patronage' (page 7).” (Dill, 2006, p. 3). At the time, there were no agreed-upon quantitative definitions of TOD. The four sites that are also included in this study were originally selected based on density (higher than typically found in the area), land use mix, pedestrian friendliness, and closeness to transit.

As mentioned in the background section, the type of TOD (or differentiation between a TOD and TAD) is likely to influence travel outcomes. Renne and Ewing (2013) suggest that development that is functionally transit-oriented, as opposed to developments that are merely located adjacent to transit, should exhibit the density of people and jobs to support transit, have diverse land uses, and walkable environments. Table 2-3 details several measures the speak to how the developments in this study fall when considering these factors.

In general, the population and jobs densities in the areas around the suburban developments in the Metro TOD program, and the study, fell below the threshold suggested by Renne and Ewing (of 30 people + jobs per acre) - only Beaverton Round met this threshold, based on a high jobs density in the quarter-mile area around the development. Renne and Ewing suggested an average block size of 6.5 acres or less as a proxy for walkability, which 6 out of 17 developments met. Finally, they suggested that buildings with adjacent land uses that included uses other than residential or commercial were important, although only the sites around Orenco Station (Nexus, Club 1201, and Orenco MFH) met that threshold. Renne and Ewing suggest tallying one point for each of the above three criteria satisfied, with a TOD needing all three satisfied, "hybrids" satisfying two of the criteria, and transit-adjacent development (TAD) satisfying zero or one item. Using this definition, only the Orenco MFH would qualify as a hybrid, and other buildings being TADs. We've also included jobs accessible by transit in Table 2-3, as that may be indicator of the usefulness of the transit itself. 
The suburban environments of most of the developments in this study may put them closer to TADs than TODs, at least by this definition. However, as part of the objective of the study is to examine travel behavior changes over time, and as neighborhoods are built up around the study buildings, we are also looking at the effect of travel behavior as the buildings move closer to the definition of TODs defined by Renne and Ewing.

Table 2-3 TOD Characteristics

\begin{tabular}{|c|c|c|c|c|c|}
\hline Name & $\begin{array}{c}\text { Population } \\
\text { Density } \\
\text { (acre) }^{1}\end{array}$ & $\begin{array}{c}\text { Jobs } \\
\text { Density } \\
\text { (acre) }^{2}\end{array}$ & $\begin{array}{c}\text { Average } \\
\text { Block size } \\
\text { (acres) }^{3}\end{array}$ & $\begin{array}{c}\text { Jobs accessible } \\
\text { within } 30 \text { mins }^{-} \\
\text {by transit }\end{array}$ & $\begin{array}{l}\text { Land use in } 1 / 4 \text { mile } \\
\text { (zoning) }\end{array}$ \\
\hline Nexus & 3.3 & 4.5 & 7.8 & 109,009 & IND, MUR, SFR \\
\hline Club 1201 & 2.7 & 3.4 & 6.8 & 109,009 & IND, MUR, MFR \\
\hline Orenco Station - MFH & 2.5 & 4.0 & 5.2 & 109,009 & IND, MFR, MUR, SFR \\
\hline $\begin{array}{l}\text { Elmonica Station } \\
\text { Condominiums }\end{array}$ & 13.6 & 2.3 & 15.3 & 195,071 & COM; MFR; MUR; SFR \\
\hline Beaverton Round & 10.2 & 31.6 & 7.6 & 303,920 & MUR \\
\hline Broadway Vantage & 11.5 & 4.6 & 8.1 & 311,509 & MFR; MUR; SFR \\
\hline Center Commons & 16.6 & 3.4 & 6.9 & 333,507 & COM; MFR; MUR; SFR \\
\hline $\begin{array}{l}\text { Center Commons } \\
\text { townhomes }\end{array}$ & 16.8 & 4.2 & 6.4 & 333,507 & COM; MFR; MUR; SFR \\
\hline Bridal Veil & 8.8 & 13.8 & 5.5 & 73,715 & MFR; MUR \\
\hline Central Point & 8.4 & 13.8 & 6.2 & 73,715 & MUR \\
\hline Gresham Central & 8.9 & 11.2 & 7.9 & 73,715 & MFR; MUR \\
\hline Landmark & 9.1 & 9.7 & 14.5 & 73,715 & MUR \\
\hline Oneonta & 8.9 & 13.7 & 5.8 & 73,715 & MFR; MUR \\
\hline Three Cedars & 8.9 & 12.9 & 7.3 & 73,715 & MUR \\
\hline 3rd Central & 7.5 & 12.6 & 8.6 & 87,938 & MFR; MUR; SFR \\
\hline The Beranger & 9.0 & 13.7 & 5.3 & 73,715 & MUR \\
\hline
\end{tabular}

1. Quarter-mile network buffer, 2017 ACS 5 year data; 2. Quarter-mile network buffer, 2015 Census Longitudinal Employer-Household Dynamics Origin-Destination Employment Statistics (LODES); 3. Quarter-mile network buffer, calculated by converting intersection density, assuming 4 intersections per block; 4 . Transit Center AllTransit tool; 5. Quarter-mile network buffer, land use zoning (IND=industrial; MUR=Mixed Use Commercial \& Residential; MFR=Multi-Family Residential; SFR=Single-Family Residential; COM=Commercial).

\section{Neighborhood Change}

To understand how neighborhood change may play a role in the travel choices of residents, it is necessary to understand the neighborhood characteristics of the buildings. This section describes certain characteristics of the neighborhoods today, as well as examines the degree of change that occurred between the baseline and second-wave survey periods. Finally, the section describes the change in certain categories - namely land-use change, destinations change, walk and bike network change, and transit change. 
Table 2-4 provides an overview of certain key factors about the neighborhood. These include the distance of the building from the Portland city center; the floor-to-area ratio for the neighborhood around the building (calculated for a buffer of 1,000 feet from the building/s taxlot/s); the population density (people per square mile based on 2018 U.S. Census for the area a quarter mile out from the geocoded building address); intersection density (intersections per square mile for the area a quarter mile out from the geocoded building address); and jobs density (jobs per square mile based on Census LODES data for the area a quarter mile out from the geocoded building address). For the groups (East Portland TODs and Gresham TODs), the data are averaged across the sites.

Table 2-4 2018 Neighborhood Characteristics

\begin{tabular}{lccccc} 
Group & $\begin{array}{l}\text { Distance from } \\
\text { Portland } \\
\text { Center }\end{array}$ & $\begin{array}{l}\text { Neighborhood } \\
\text { Floor Area } \\
\text { Ratio (FAR), } \\
\text { 2018 }\end{array}$ & $\begin{array}{c}\text { Population } \\
\text { Density, 2018 }\end{array}$ & $\begin{array}{c}\text { Intersection } \\
\text { Density, 2018 }\end{array}$ & $\begin{array}{c}\text { Jobs Density, } \\
\mathbf{2 0 1 8}\end{array}$ \\
\hline East Portland TODs & 3.8 & 0.141 & 8,983 & 345 & 2,570 \\
Gresham Central & 11.8 & 0.060 & 5,681 & 325 & 7,143 \\
Gresham TODs & 11.8 & 0.057 & 5,538 & 375 & 8,241 \\
Beaverton Round & 7.3 & 0.262 & 6,539 & 335 & 20,215 \\
Nexus Apartments & 12.1 & 0.467 & 2,083 & 328 & 2,884 \\
Club 1201 & 11.9 & 0.496 & 1,723 & 374 & 2,156 \\
Orenco MFH & 12.1 & 0.350 & 1,617 & 489 & 2,567 \\
Elmonica Condos & 9.0 & 0.301 & 8,677 & 167 & 1,500 \\
\hline
\end{tabular}

We then looked at changes in these neighborhoods between the baseline survey and 2018. Table 2-5 provides the change in these land-use and population variables, while Table 2-6 examines the change in transportation variables. Table 2-7 provides definitions of variables used in these tables. 
Table 2-5 Neighborhood Built Environment Change Between Baseline and Second-Wave Survey Years

\begin{tabular}{lccccc}
\multicolumn{1}{c}{ Building } & $\begin{array}{l}\text { Change in } \\
\text { Building } \\
\text { Square Footage }\end{array}$ & $\begin{array}{l}\text { Percentage of Taxlot } \\
\text { Area of Buildings } \\
\text { Built After Baseline } \\
\text { Survey Year }\end{array}$ & $\begin{array}{l}\text { Change in } \\
\text { Population } \\
\text { Density }\end{array}$ & $\begin{array}{l}\text { Change in } \\
\text { Intersectio } \\
\text { n Density }\end{array}$ & $\begin{array}{c}\text { Change } \\
\text { in Jobs } \\
\text { Density }\end{array}$ \\
\hline East Portland TODs & $4 \%$ & $2 \%$ & $17 \%$ & $26 \%$ & $25 \%$ \\
Gresham Central & $10 \%$ & $0 \%$ & $43 \%$ & $42 \%$ & $12 \%$ \\
Gresham TODs & $7 \%$ & $0 \%$ & $26 \%$ & $35 \%$ & $20 \%$ \\
Beaverton Round & $5 \%$ & $4 \%$ & $71 \%$ & $131 \%$ & $230 \%$ \\
Nexus Apartments & $76 \%$ & $10 \%$ & $45 \%$ & $10 \%$ & $30 \%$ \\
Club 1201 & $163 \%$ & $15 \%$ & $45 \%$ & $74 \%$ & $44 \%$ \\
Orenco MFH & $33 \%$ & $8 \%$ & $27 \%$ & $15 \%$ & $51 \%$ \\
Elmonica Condos & $87 \%$ & $10 \%$ & $10 \%$ & $8 \%$ \\
\hline
\end{tabular}

Note: “Gresham TODS” includes Bridal Veil, Central Point, Landmark, Oneonta, Three Cedars, 3rd Central, and The Beranger

Table 2-6 Neighborhood Transportation Environment Change Between Baseline and Second-Wave Survey Years

\begin{tabular}{ccccc} 
Building & $\begin{array}{c}\text { Change in } \\
\text { Sidewalk Density }\end{array}$ & $\begin{array}{c}\text { Change in Bike } \\
\text { Route Miles }\end{array}$ & $\begin{array}{c}\text { New MAX } \\
\text { Lines }\end{array}$ & $\begin{array}{c}\text { Change in Number } \\
\text { of Bus Routes }\end{array}$ \\
\hline East Portland TODs & $0 \%$ & $0 \%$ & 1 & $25 \%$ \\
Gresham Central & $12 \%$ & $243 \%$ & 0 & $0 \%$ \\
Gresham TODs & $11 \%$ & $123 \%$ & 0 & $-5 \%$ \\
Beaverton Round & $17 \%$ & $0 \%$ & 0 & $0 \%$ \\
Nexus Apartments & $45 \%$ & $79 \%$ & 0 & $0 \%$ \\
Club 1201 & $17 \%$ & $-32 \%$ & 0 & $0 \%$ \\
Orenco MFH & $3 \%$ & $-36 \%$ & 0 & $100 \%$ \\
Elmonica Condos & $24 \%$ & $62 \%$ & 0 & $0 \%$ \\
\hline
\end{tabular}


Table 2-7 Neighborhood Change Variable Descriptions

\begin{tabular}{|c|c|c|}
\hline Variable & Variable Description & Buffer Area \\
\hline $\begin{array}{l}\text { Change in Building Square } \\
\text { Footage }\end{array}$ & $\begin{array}{l}\text { Percentage increase in building square feet } \\
\text { in } 2018 \text { compared to building square feet in } \\
\text { baseline year }\end{array}$ & $\begin{array}{l}\text { 1,000 feet out from building / } \\
\text { development taxlot }\end{array}$ \\
\hline $\begin{array}{l}\text { Percent of Taxlot Area of } \\
\text { Buildings Built After Baseline } \\
\text { Survey Year }\end{array}$ & $\begin{array}{l}\text { Percentage of taxlot area of buildings built } \\
\text { after baseline survey year }\end{array}$ & $\begin{array}{l}\text { 1,000 feet out from building / } \\
\text { development taxlot }\end{array}$ \\
\hline Change in Population Density & $\begin{array}{l}\text { Change in population density from baseline } \\
\text { survey year to } 2018\end{array}$ & $\begin{array}{l}\text { Quarter mile from geocoded } \\
\text { site address }\end{array}$ \\
\hline Change in Intersection Density & $\begin{array}{l}\text { Change in intersection density from } \\
\text { baseline survey year to } 2018\end{array}$ & $\begin{array}{l}\text { Quarter mile from geocoded } \\
\text { site address }\end{array}$ \\
\hline Change in Jobs Density & $\begin{array}{l}\text { Change in jobs density from baseline } \\
\text { survey year to } 2018\end{array}$ & $\begin{array}{l}\text { Quarter mile from geocoded } \\
\text { site address }\end{array}$ \\
\hline Change in Sidewalk Density & $\begin{array}{l}\text { Change in the number of MAX lines within } \\
\text { the buffer area from baseline survey year to } \\
2018\end{array}$ & $\begin{array}{l}\text { 1,000 feet out from building / } \\
\text { development taxlot }\end{array}$ \\
\hline New MAX Lines & $\begin{array}{l}\text { Change in the number of MAX lines within } \\
\text { the buffer area from baseline survey year to } \\
2018\end{array}$ & $\begin{array}{l}\text { Quarter mile from geocoded } \\
\text { site address }\end{array}$ \\
\hline $\begin{array}{l}\text { Change in Number of Bus } \\
\text { Routes }\end{array}$ & $\begin{array}{l}\text { Change in the number of bus routes with } \\
\text { stops in the buffer area from the baseline } \\
\text { survey year to } 2018\end{array}$ & $\begin{array}{l}\text { Quarter mile from geocoded } \\
\text { site address }\end{array}$ \\
\hline Change in Bike Route Miles & $\begin{array}{l}\text { Change in the mileage of bike routes in the } \\
\text { buffer area from the baseline survey year to } \\
2018\end{array}$ & $\begin{array}{l}\text { Quarter mile from geocoded } \\
\text { site address }\end{array}$ \\
\hline
\end{tabular}

Using the change calculations, the buildings were assigned into categories of change for land use (minor, moderate or major); destinations (minor, moderate, major); walk and bike network (none, minor, major); and transit (yes, no) - see Table 2-8. The assignments were based on looking at change in key related variables, and identifying subjective segment cutoffs.

For land-use change, the change in developed square footage within the 1,000-foot buffer was used - Nexus apartments, Club 1201 and Elmonica Condos all saw increases of $75 \%$ or greater and were considered major change, while Orenco MFH saw an increase of $33 \%$ and was considered moderate change. Other buildings saw developed square footage increases of $10 \%$ or less, and were considered minor.

Destinations change was based on the change in jobs density as proxy for the number of places you might be able to visit. Beaverton Round (230\% increase), Orenco MFH (51\% increase), and Club 1201 (44\% increase) were placed in the major change group, while Nexus Apartments (30\%), East Portland TODs (25\%) and Gresham TODs (20\%) were considered moderate change. Gresham Central saw an increase of $12 \%$ and was considered minor change.

For walk and bike change, the change in sidewalk density and change in bike route miles were considered. Gresham Central and Gresham TODs saw major changes in the bike network, and 
were considered major change overall. Nexus apartments and Elmonica Condos both saw considerable increases in both the sidewalk density and bike route miles, and were considered major change overall. Beaverton Round and Club 1201 saw small increases in sidewalk density and were rated as minor change. Finally, East Portland TODs and Orenco MFH saw no or nearly no increase in the walk or bike network.

Finally, transit change was based on if there were new MAX lines or bus routes accessible within a quarter mile of the building address. The East Portland TODs were adjacent to the MAX Green line, while the Orenco MFH saw a doubling in the number of bus routes serving the location. All other buildings were listed as no change.

Table 2-8 Neighborhood change category designations

\begin{tabular}{lllll} 
Building & $\begin{array}{l}\text { Land-Use } \\
\text { Change }\end{array}$ & $\begin{array}{l}\text { Destinations } \\
\text { Change }\end{array}$ & $\begin{array}{l}\text { Walk Bike } \\
\text { Network Change }\end{array}$ & $\begin{array}{l}\text { Transit } \\
\text { Change }\end{array}$ \\
\hline East Portland TODs & Minor & Moderate & None & Yes \\
Gresham Central & Minor & Minor & Major & No \\
Gresham TODs & Minor & Moderate & Major & No \\
Beaverton Round & Minor & Major & Minor & No \\
Nexus Apartments & Major & Moderate & Major & No \\
Club 1201 & Major & Major & Minor & No \\
Orenco MFH & Moderate & Major & None & Yes \\
Elmonica Condos & Major & Minor & Major & No \\
\hline
\end{tabular}

\section{Survey Development}

The project team reviewed the survey instrument from prior survey rounds in 2005, 2007, 2010, 2014, and 2018 ("baseline” surveys). The initial 2005 survey was developed borrowing (with permission) from two other sets of researchers and previous work by the author (Dill, 2006). The first was a survey used by Professors Hollie Lund, Richard Willson, and Robert Cervero in their research on TODs in California, "Travel Characteristics of Transit-Oriented Development in California.” That survey focused on collecting commute information and data about three recent trips. The other survey that we borrowed from was developed by Professors Susan Handy and Patricia Mokhtarian at the University of California, Davis. The survey was used in a study of several neighborhoods in California, focusing on people who had recently moved. That survey collected broader information about travel, particularly non-work travel, along with information about travel and housing preferences and decisions.

The initial 2005 survey asked respondents to recall for the past week (defined by dates on the form) the number of trips they made from home by various modes (private vehicle, walk, bicycle, bus, and MAX) for 13 purposes. This was done to estimate a "trip generation" rate for the development. After the 2005 survey, this portion of the form was replaced with a separate one-day travel diary. Both eight-page survey forms included the following sections: 
- Information on your Household. This included questions on household size and number of vehicles.

- Information on your Place of Work/School and Commuting.

- Information on Commuting from your Prior Residence

- Your daily travel. This section focused on non-work travel during different times of the year.

- Information on your Current Place of Residence. This section focused on the importance of various items in selecting their home. Most of the questions came from the Handy and Mokhtarian instrument. In the second phase, a series of questions on sense of community were included.

- Information on your Travel Preferences. This section attempts to gauge people's preferences for various modes and was developed by Handy and Mokhtarian.

- Your household vehicles. This section includes a question from Handy and Mokhtarian about changes in vehicle ownership resulting from characteristics of their current neighborhood.

- Information about you. This section includes standard demographic questions and some questions about mobility impairments.

Surveys for subsequent years generally followed this format, with most of the questions remaining identical from year to year in order to allow for comparison. However, minor changes were made:

- 2007: One-day travel diary was replaced with a "trip log" where respondents would note how many trips they made, for what purposes, and by what modes. The goal was to reduce the burden on the survey taker, but still allow for trip generation rates.

- 2010: The separate trip log was replaced with a set of guided questions within the main questionnaire about up to seven trips they took from home on the most recent Tuesday. The questions asked where they went, how they got there, and how they got home. To include the guided questions, but keep the survey the same overall length (eight pages), several questions were cut, including questions about the frequency of walk, bike or transit trips taken during wet and cold weather. One set of questions on their views about their neighborhood was removed. A few other minor edits were made, including updating carshare options to include Zipcar.

- 2014: Based on feedback from Metro staff, we made efforts to reduce the number of questions in certain sections in order to reduce the burden on survey respondents. This consisted primarily of reducing the number of options included in the list of factors that were (or were not) important to the respondent in selecting their home, and statements about their travel preferences. On the trip log, we asked about any trips made during the day, and not only trips made to and from home. This was done in order to understand if trip-chaining was occurring. Mobility options were again updated to include new carsharing options. We included a question on how many bike trips they had made in the 
past 30 days. We updated questions about how their new residence differed from their prior residence in terms of size, cost and commute.

- The 2018 survey was very similar to the 2014 survey, except that some travel options were updated to include options such as Uber, Lyft, and bike share.

For the second-wave survey, the project team sought to maintain consistency with past survey instruments as much as possible to allow for comparison. A few of the questions removed for the 2014 cycle to reduce survey length were added back in to allow for comparison. New transportation options since those baseline surveys, such as Uber, Lyft, car share and bike share, were included in the new instrument as well.

\section{Survey Implementation}

\section{Mailing Addresses and Names}

The research team first pulled building addresses and unit numbers from baseline survey mailing lists. Then, we used InfoUSA to identify residents' names for as many units as possible. Approximately $50 \%$ of the units had names associated with them through the service. In cases where more than one name was associated with a unit, one of the names was selected at random.

\section{Survey Packet}

Survey invitations were sent to every unit in the identified buildings. For units with associated names (from InfoUSA), the first mailing was sent to that name, with "or Current Resident” included. For units without an associated name, the mailing went to "Current Resident." An initial packet included a personalized letter inviting any adult living in the unit to take the survey online, with a URL link provided. The URL was a simple-to-type shortened address - for example "https://tinyurl.com/PSUtravelsurvey". A unique code was also included with each letter which allowed the research team to mark a unit as complete. The initial packet also had a pullout postcard printed on brightly colored paper that included the link to the survey and survey code. Residents were given a deadline approximately 10 days from the receipt of the packet to complete the survey.

Several days after the initial packet was mailed out, the research team mailed out a reminder postcard, letting people know that there was "still time" to complete the survey, and providing the URL and code again.

As completed surveys were submitted online, the units were marked as complete. For units without completed surveys, a second packet was sent out right after the first deadline. The new packet provided an extra 10 days to complete the survey. The new packet also contained two paper copies of the survey and a return envelope. This method allowed more than one adult in the household to complete the survey, either online or on paper.

\section{Compensation}

All respondents were offered a \$5 Starbucks card for completing the survey. For people taking the survey online, their name and mailing address could be entered after taking the survey. For people sending back paper versions of the survey, a paper slip was included that had a place to enter their name and address. We also offered a drawing for one of 10 \$100 Amazon gift cards, which was in addition to the Starbucks card. 


\section{Time of Year}

The project team reviewed the baseline survey implementation schedule to identify potential seasonality effects, and decided to break the second-wave survey distribution into a fall group and a spring group, with those buildings that were originally surveyed in the fall primarily in one group, and those surveyed between late spring and early summer in another group. The exception to this were three Gresham and East Portland sites that were surveyed in fall 2010 - for the second wave, these sites were included with our 2007 east-side sites and surveyed in the spring to match those sites. See Table 2-9 for a building-by-building breakdown of the baseline and second-wave survey months.

In an attempt to increase response rates for TODs that had received survey invitations in the fall of 2018, a third packet was also sent to the units that had not yet responded at the time of the spring 2019 survey. Although these units were less likely to respond, since they had already failed to respond to two packets and a postcard, we were able to increase the response rates for these buildings by a total of $10 \%$.

Table 2-9 Baseline and Second-Wave Survey Timing

\begin{tabular}{lll}
\hline Building & Baseline survey & Wave 2 survey \\
\hline Nexus & November 2010 & Nov 2018 \\
Club 1201 & Sept/Oct 2005 & Nov 2018 \\
Orenco Station - MFH & Sept/Oct 2005 & Nov 2018 \\
Elmonica Station Condominiums & Sept/Oct 2005 & Nov 2018 \\
Beaverton Round & Sept/Oct 2005 & Nov 2018 \\
3rd Central & September 2010 & May 2019 \\
Broadway Vantage & September 2010 & May 2019 \\
The Beranger & November 2010 & May 2019 \\
Gresham Central & June 2007 & May 2019 \\
Central Point & June 2007 & May 2019 \\
Center Commons townhomes & June 2007 & May 2019 \\
Center Commons & June 2007 & May 2019 \\
Oneonta & June 2007 & May 2019 \\
Bridal Veil & June 2007 & May 2019 \\
Landmark & June 2007 & May 2019 \\
Three Cedars & June 2007 & May 2019 \\
\hline
\end{tabular}




\section{Respondents}

A total of 309 responses from 262 units were received for the 2018-2019 second-wave (or "Wave 2") survey, accounting for a response rate of $24 \%$, which was calculated by taking the number of responding units divided by the number of units receiving the survey (units invited minus survey packets returned as vacant). As noted in the Methodology, more than one adult in each household could complete a survey. The overall response rate of $24 \%$ is slightly below the $29 \%$ for the baseline surveys of these locations. The completions and response rates are shown in Table 3-1. Note that, in an effort to gather enough responses together for analysis, buildings with similar characteristics and geographic locations were grouped together in Gresham (Gresham TODs) and East Portland (East Portland TODs); the individual building completions and response rates are shown in Table 3-2 for these buildings. The total number of surveys is similar, although there is some variation across buildings; notably, for the second-wave survey we had fewer responses for the East Portland TODs (Center Commons and Broadway Vantage), and Nexus apartments, and more responses for Club 1201.

Table 3-1 Response Rates

\begin{tabular}{|c|c|c|c|c|c|}
\hline & \multicolumn{2}{|c|}{ Baseline Collection } & \multicolumn{3}{|c|}{ Wave 2 (2018 / 2019) } \\
\hline & $\begin{array}{c}\# \\
\text { Completions } \\
\end{array}$ & $\begin{array}{c}\text { Response } \\
\text { Rate }\end{array}$ & $\begin{array}{c}\# \\
\text { Completions } \\
\end{array}$ & $\begin{array}{l}\text { \# Units } \\
\text { responding }\end{array}$ & $\begin{array}{c}\text { Response } \\
\text { Rate }\end{array}$ \\
\hline East Portland TODs & 26 & $20 \%$ & 16 & 15 & $13 \%$ \\
\hline Gresham Central & 18 & $21 \%$ & 16 & 15 & $17 \%$ \\
\hline Gresham TODs & 31 & $25 \%$ & 33 & 28 & $19 \%$ \\
\hline Beaverton Round & 13 & $25 \%$ & 17 & 12 & $24 \%$ \\
\hline Nexus Apartments & 142 & $41 \%$ & 102 & 85 & $29 \%$ \\
\hline Club 1201 & 23 & $24 \%$ & 59 & 53 & $31 \%$ \\
\hline Orenco MFH & 28 & $28 \%$ & 36 & 29 & $22 \%$ \\
\hline Elmonica Condos & 26 & $24 \%$ & 30 & 25 & $23 \%$ \\
\hline Total & 307 & $29 \%$ & 309 & 262 & $24 \%$ \\
\hline
\end{tabular}


Table 3-2 Grouped Buildings

\begin{tabular}{|c|c|c|c|c|c|}
\hline & \multicolumn{2}{|c|}{ Baseline Collection } & \multicolumn{3}{|c|}{ Wave 2 (2018 / 2019) } \\
\hline & $\begin{array}{c}\# \\
\text { Completions }\end{array}$ & $\begin{array}{c}\text { Response } \\
\text { Rate }\end{array}$ & $\begin{array}{c}\# \\
\text { Completions } \\
\end{array}$ & $\begin{array}{c}\text { \# Units } \\
\text { Responding }\end{array}$ & $\begin{array}{c}\text { Response } \\
\text { Rate }\end{array}$ \\
\hline \multicolumn{6}{|c|}{ East Portland TODs } \\
\hline Center Commons & 11 & $17 \%$ & 9 & 9 & $16 \%$ \\
\hline Broadway Vantage & 15 & $21 \%$ & 7 & 6 & $11 \%$ \\
\hline \multicolumn{6}{|c|}{ Gresham TODs } \\
\hline 3rd Central & 11 & $32 \%$ & 5 & 3 & $9 \%$ \\
\hline The Beranger & 5 & $24 \%$ & 2 & 2 & $10 \%$ \\
\hline Oneonta & 8 & $47 \%$ & 7 & 7 & $35 \%$ \\
\hline Bridal Veil & 2 & $25 \%$ & 3 & 3 & $50 \%$ \\
\hline Landmark & 4 & $15 \%$ & 8 & 6 & $22 \%$ \\
\hline Three Cedars & 1 & $8 \%$ & 4 & 3 & $19 \%$ \\
\hline Central Point & 0 & $0 \%$ & 4 & 4 & $19 \%$ \\
\hline
\end{tabular}

There are some differences in the composition of who took the survey between the baseline and second-wave fieldings (see Table 3-3). Overall, the percentage of women in the sample dropped from $66 \%$ to $58 \%$, while the average age increased from 41.2 to 45.5 . Both differences were significant. While some of the gender differences for specific buildings were even greater (for example, the percentage of female respondents dropped from $77 \%$ to $57 \%$ for the East Portland TODs, and increased from $38 \%$ to $56 \%$ for Beaverton Round), most of those differences were not significant due to small sample sizes. The only building with a significant difference was Elmonica Condos, which dropped from 77\% female respondents to $50 \%$.

The story for average age is similar, with Gresham Central's average age falling from 48.9 to 39.3, Beaverton Round increasing from 41.1 to 46.3, Club 1201 increasing from 49.3 to 57.4, Orenco MFH increasing from 51.3 to 56.3, and Elmonica Condos increasing from 32.5 to 39.9. However, only Elmonica Condos’ difference was significant.

We also compared how long the respondent had been living in their residence for the original and second-wave period. For all locations, the residents in the second-wave survey had been living there longer, which is not surprising since most buildings were quite new in the baseline survey. Perhaps most notable are the short average length of residence for the Nexus apartments (1.4 years on average) and Elmonica Condos (2.8 years on average). 
Table 3-3 Respondent Age, Gender, and Occupancy Length

\begin{tabular}{lcccccc}
\hline \multicolumn{1}{c}{ Building } & \multicolumn{2}{c}{ Percentage Female } & \multicolumn{2}{c}{ Average Age } & \multicolumn{2}{c}{ Years Living in Residence } \\
& Baseline & Wave 2 & Baseline & Wave 2 & Baseline & Wave 2 \\
\hline East Portland TODs & $77 \%$ & $57 \%$ & 40.6 & 42.5 & $\mathbf{1 . 8}$ & $\mathbf{6 . 7}$ \\
Gresham Central & $72 \%$ & $67 \%$ & 48.9 & 39.3 & 3.1 & 5.2 \\
Gresham TODs & $61 \%$ & $59 \%$ & 55.4 & 53.4 & $\mathbf{2 . 1}$ & $\mathbf{7 . 1}^{*}$ \\
Beaverton Round & $38 \%$ & $56 \%$ & 41.1 & 46.3 & $\mathbf{1 . 1}$ & $\mathbf{4 . 9}$ \\
Nexus Apartments & $65 \%$ & $57 \%$ & 35.5 & 34.5 & $\mathbf{1 . 1}$ & $\mathbf{1 . 8}$ \\
Club 1201 & $70 \%$ & $64 \%$ & 49.3 & 57.4 & $\mathbf{3 . 5}$ & $\mathbf{5 . 9 *}$ \\
Orenco MFH & $63 \%$ & $53 \%$ & 51.3 & 56.3 & $\mathbf{2 . 0}$ & $\mathbf{6 . 2 *}$ \\
Elmonica Condos & $77 \%$ & $\mathbf{5 0 \% *}$ & 32.5 & $\mathbf{3 9 . 9 *}$ & $\mathbf{0 . 4}$ & $\mathbf{3 . 0}$ \\
\hline Total & $66 \%$ & $\mathbf{5 8 \% *}$ & 41.2 & $\mathbf{4 5 . 5 *}$ & $\mathbf{1 . 6}$ & $\mathbf{4 . 4}$ \\
\hline
\end{tabular}

*Significant at $<.05$, Chi-Square (\%) or t-test (means)

Table 3-4 provides the stated race and ethnicity of survey respondents for each building or group at the time of the baseline and second-wave surveys. Note that respondents were able to select all that apply for this question, resulting in combined percentages higher than $100 \%$ in some cases. The relatively low sample sizes limited our ability to identify significant differences in race and ethnicity make-up by building. Overall, the sample had a slightly higher ratio of Asian and Hispanic respondents in the second wave than in the baseline.

Table 3-4 Respondent Race / Ethnicity

\begin{tabular}{|c|c|c|c|c|c|c|c|c|c|}
\hline Building & Survey & White & $\begin{array}{c}\text { African } \\
\text { American }\end{array}$ & Asian & Hispanic & $\begin{array}{c}\text { Native } \\
\text { American } \\
\end{array}$ & $\begin{array}{c}\text { Pacific } \\
\text { Islander }\end{array}$ & Other & $\mathbf{n}$ \\
\hline \multirow{2}{*}{$\begin{array}{l}\text { East Portland } \\
\text { TODs }\end{array}$} & Baseline & $58 \%$ & $42 \%$ & $4 \%$ & $4 \%$ & $19 \%$ & $0 \%$ & $4 \%$ & 26 \\
\hline & Wave 2 & $71 \%$ & $21 \%$ & $0 \%$ & $0 \%$ & $14 \%$ & $0 \%$ & $7 \%$ & 14 \\
\hline \multirow{2}{*}{$\begin{array}{c}\text { Gresham } \\
\text { Central }\end{array}$} & Baseline & $83 \%$ & $0 \%$ & $6 \%$ & $0 \%$ & $0 \%$ & $6 \%$ & $6 \%$ & 18 \\
\hline & Wave 2 & $79 \%$ & $0 \%$ & $7 \%$ & $7 \%$ & $0 \%$ & $14 \%$ & $0 \%$ & 14 \\
\hline \multirow{2}{*}{$\begin{array}{l}\text { Gresham } \\
\text { TODs }\end{array}$} & Baseline & $97 \%$ & $0 \%$ & $3 \%$ & $3 \%$ & $0 \%$ & $0 \%$ & $3 \%$ & 31 \\
\hline & Wave 2 & $90 \%$ & $0 \%$ & $10 \%$ & $7 \%$ & $0 \%$ & $0 \%$ & $0 \%$ & 30 \\
\hline \multirow{2}{*}{$\begin{array}{c}\text { Beaverton } \\
\text { Round }\end{array}$} & Baseline & $69 \%$ & $0 \%$ & $15 \%$ & $15 \%$ & $8 \%$ & $0 \%$ & $0 \%$ & 13 \\
\hline & Wave 2 & $81 \%$ & $13 \%$ & $13 \%$ & $0 \%$ & $0 \%$ & $0 \%$ & $0 \%$ & 16 \\
\hline \multirow{2}{*}{$\begin{array}{c}\text { Nexus } \\
\text { Apartments }\end{array}$} & Baseline & $74 \%$ & $3 \%$ & $21 \%$ & $2 \%$ & $1 \%$ & $2 \%$ & $1 \%$ & 135 \\
\hline & Wave 2 & $59 \%$ & $1 \%$ & $29 \%$ & $12 \%$ & $3 \%$ & $0 \%$ & $2 \%$ & 90 \\
\hline \multirow{2}{*}{ Club 1201} & Baseline & $91 \%$ & $0 \%$ & $0 \%$ & $0 \%$ & $0 \%$ & $9 \%$ & $0 \%$ & 22 \\
\hline & Wave 2 & $74 \%$ & $0 \%$ & $14 \%$ & $7 \%$ & $5 \%$ & $0 \%$ & $7 \%$ & 58 \\
\hline \multirow{2}{*}{$\begin{array}{c}\text { Orenco } \\
\text { MFH }\end{array}$} & Baseline & $96 \%$ & $0 \%$ & $4 \%$ & $0 \%$ & $0 \%$ & $0 \%$ & $0 \%$ & 26 \\
\hline & Wave 2 & $89 \%$ & $3 \%$ & $11 \%$ & $0 \%$ & $3 \%$ & $0 \%$ & $0 \%$ & 36 \\
\hline \multirow{2}{*}{$\begin{array}{c}\text { Elmonica } \\
\text { Condos }\end{array}$} & Baseline & $77 \%$ & $0 \%$ & $8 \%$ & $8 \%$ & $0 \%$ & $8 \%$ & $4 \%$ & 26 \\
\hline & Wave 2 & $67 \%$ & $4 \%$ & $30 \%$ & $4 \%$ & $0 \%$ & $0 \%$ & $0 \%$ & 27 \\
\hline \multirow{2}{*}{ Total } & Baseline & $79 \%$ & $5 \%$ & $12 \%$ & $3 \%$ & $2 \%$ & $3 \%$ & $2 \%$ & 301 \\
\hline & Wave 2 & $73 \%$ & $3 \%$ & $18 \% *$ & 7\%* & $3 \%$ & $1 \%$ & $2 \%$ & 286 \\
\hline
\end{tabular}

*Significant at <.05, Chi-Square 
Table 3-5 provides the employment and student statuses of respondents. Respondents were able to select more than one option, so the totals may add up to more than $100 \%$. Again, sample size limited the significance of findings for individual buildings or groups. Across all TODs, the percentage of students dropped from $16 \%$ to $7 \%$. While not significant, three of the buildings Elmonica Condos, Beaverton Round, and Club 1201 - dropped from 26\%, 15\% and 10\% of respondents indicating they were students, respectively, down to $0 \%$. Meanwhile, the percentage of retirees increased from 11\% to 20\%. Though not significant, Club 1201 went from 19\% to $37 \%$ retirees, while Orenco MFH went from $12 \%$ to $38 \%$.

Table 3-5 Respondent Employment / Student Status

\begin{tabular}{|c|c|c|c|c|c|c|c|c|}
\hline Building & Survey & $\begin{array}{l}\text { Employed } \\
\text { Full Time }\end{array}$ & $\begin{array}{l}\text { Employed } \\
\text { Part Time }\end{array}$ & Student & $\begin{array}{l}\text { Looking } \\
\text { for Work }\end{array}$ & $\begin{array}{l}\text { Not Employed } \\
\text { Outside Home }\end{array}$ & Retired & $\mathbf{n}$ \\
\hline \multirow{2}{*}{$\begin{array}{l}\text { East Portland } \\
\text { TODs }\end{array}$} & Baseline & $31 \%$ & $8 \%$ & $15 \%$ & $19 \%$ & $15 \%$ & $12 \%$ & 26 \\
\hline & Wave 2 & $53 \%$ & $13 \%$ & $13 \%$ & $0 \%$ & $7 \%$ & $13 \%$ & 15 \\
\hline \multirow{2}{*}{$\begin{array}{c}\text { Gresham } \\
\text { Central }\end{array}$} & Baseline & $65 \%$ & $12 \%$ & $0 \%$ & $0 \%$ & $6 \%$ & $18 \%$ & 17 \\
\hline & Wave 2 & $67 \%$ & $13 \%$ & $0 \%$ & $0 \%$ & $0 \%$ & $13 \%$ & 15 \\
\hline \multirow{2}{*}{$\begin{array}{l}\text { Gresham } \\
\text { TODs }\end{array}$} & Baseline & $47 \%$ & $23 \%$ & $0 \%$ & $0 \%$ & $0 \%$ & $33 \%$ & 30 \\
\hline & Wave 2 & $50 \%$ & $7 \%$ & $3 \%$ & $0 \%$ & $3 \%$ & $37 \%$ & 30 \\
\hline \multirow{2}{*}{$\begin{array}{c}\text { Beaverton } \\
\text { Round }\end{array}$} & Baseline & $85 \%$ & $0 \%$ & $15 \%$ & $0 \%$ & $8 \%$ & $0 \%$ & 13 \\
\hline & Wave 2 & $80 \%$ & $7 \%$ & $0 \%$ & $0 \%$ & $0 \%$ & $7 \%$ & 15 \\
\hline \multirow{2}{*}{$\begin{array}{c}\text { Nexus } \\
\text { Apartments }\end{array}$} & Baseline & $58 \%$ & $7 \%$ & $24 \%$ & $3 \%$ & $6 \%$ & $6 \%$ & $\begin{array}{c}14 \\
2\end{array}$ \\
\hline & Wave 2 & $60 \%$ & $9 \%$ & $18 \%$ & $8 \%$ & $1 \%$ & $8 \%$ & 92 \\
\hline \multirow{2}{*}{ Club 1201} & Baseline & $71 \%$ & $5 \%$ & $10 \%$ & $0 \%$ & $5 \%$ & $19 \%$ & 21 \\
\hline & Wave 2 & $47 \%$ & $9 \%$ & $0 \%$ & $0 \%$ & $0 \%$ & $37 \%$ & 57 \\
\hline \multirow{2}{*}{ Orenco MFH } & Baseline & $73 \%$ & $12 \%$ & $0 \%$ & $0 \%$ & $4 \%$ & $12 \%$ & 26 \\
\hline & Wave 2 & $38 \%$ & $6 \%$ & $3 \%$ & $0 \%$ & $3 \%$ & $38 \%$ & 34 \\
\hline \multirow{2}{*}{$\begin{array}{l}\text { Elmonica } \\
\text { Condos }\end{array}$} & Baseline & $87 \%$ & $4 \%$ & $26 \%$ & $4 \%$ & $4 \%$ & $0 \%$ & 23 \\
\hline & Wave 2 & $79 \%$ & $4 \%$ & $0 \%$ & $0 \%$ & $14 \%$ & $4 \%$ & 28 \\
\hline \multirow{2}{*}{ Total } & Baseline & $60 \%$ & $9 \%$ & $16 \%$ & $3 \%$ & $6 \%$ & $11 \%$ & $\begin{array}{c}29 \\
8\end{array}$ \\
\hline & Wave 2 & $57 \%$ & $8 \%$ & $7 \% *$ & $2 \%$ & $3 \%$ & $20 \% *$ & $\begin{array}{c}28 \\
6 \\
\end{array}$ \\
\hline
\end{tabular}

*Significant at $<.05$, Chi-Square

Table 3-6 shows the educational attainment of respondents. Nexus Apartments saw a significant increase in respondents with graduate degrees, increasing from $0 \%$ to $36 \%$, while the percentage of respondents with a four-year degree dropped by a similar amount - from $77 \%$ to $38 \%$. Club 1201 saw a drop in respondents with "some college" from 35\% to 7\%, with a shift to higher education levels. Overall trends across the buildings showed a similar trend, with fewer respondents having only a high school degree or some college, or a four-year degree, and more with graduate degrees (which increased overall from 12\% to 33\%). Though not significant, other buildings with considerable jumps in respondents with graduate degrees included Gresham Central (6\% to 20\%), Club 1201 (26\% to 37\%), and Elmonica Condos (19\% to 36\%). 
Table 3-6 Education Attainment

\begin{tabular}{|c|c|c|c|c|c|c|c|c|c|c|}
\hline Building & Survey & $\begin{array}{c}\text { Some } \\
\text { HS or } \\
\text { Less }\end{array}$ & $\begin{array}{c}\text { HS } \\
\text { Dipl. or } \\
\text { GED }\end{array}$ & $\begin{array}{c}\text { Some } \\
\text { College }\end{array}$ & $\begin{array}{c}\text { Trade / } \\
\text { Voc. } \\
\text { School }\end{array}$ & $\begin{array}{l}\text { Assoc. } \\
\text { Degree }\end{array}$ & $\begin{array}{c}\text { 4-yr } \\
\text { College } \\
\text { Degree }\end{array}$ & $\begin{array}{c}\text { Grad. } \\
\text { Degree }\end{array}$ & Othel & $\mathbf{n}$ \\
\hline \multirow{2}{*}{$\begin{array}{c}\text { East Portland } \\
\text { TODs }\end{array}$} & Baseline & $\begin{array}{l}12 \\
\%\end{array}$ & $8 \%$ & $36 \%$ & $0 \%$ & $8 \%$ & $20 \%$ & $16 \%$ & $0 \%$ & 25 \\
\hline & Wave 2 & $0 \%$ & $0 \%$ & $36 \%$ & $7 \%$ & $7 \%$ & $21 \%$ & $21 \%$ & $7 \%$ & 14 \\
\hline \multirow{2}{*}{$\begin{array}{c}\text { Gresham } \\
\text { Central }\end{array}$} & Baseline & $0 \%$ & $22 \%$ & $39 \%$ & $0 \%$ & $0 \%$ & $33 \%$ & $6 \%$ & $0 \%$ & 18 \\
\hline & Wave 2 & $0 \%$ & $7 \%$ & $13 \%$ & $0 \%$ & $13 \%$ & $40 \%$ & $20 \%$ & $7 \%$ & 15 \\
\hline \multirow{2}{*}{$\begin{array}{l}\text { Gresham } \\
\text { TODs }\end{array}$} & Baseline & $0 \%$ & $10 \%$ & $39 \%$ & $3 \%$ & $6 \%$ & $29 \%$ & $13 \%$ & $0 \%$ & 31 \\
\hline & Wave 2 & $0 \%$ & $10 \%$ & $30 \%$ & $3 \%$ & $13 \%$ & $27 \%$ & $13 \%$ & $3 \%$ & 30 \\
\hline \multirow{2}{*}{$\begin{array}{l}\text { Beaverton } \\
\text { Round }\end{array}$} & Baseline & $0 \%$ & $0 \%$ & $23 \%$ & $0 \%$ & $0 \%$ & $38 \%$ & $38 \%$ & $0 \%$ & 13 \\
\hline & Wave 2 & $0 \%$ & $0 \%$ & $19 \%$ & $0 \%$ & $6 \%$ & $44 \%$ & $31 \%$ & $0 \%$ & 16 \\
\hline \multirow{2}{*}{$\begin{array}{c}\text { Nexus } \\
\text { Apartments }\end{array}$} & Baseline & $0 \%$ & $3 \%$ & $13 \%$ & $0 \%$ & $8 \%$ & $77 \%$ & $0 \%$ & $0 \%$ & 142 \\
\hline & Wave 2 & $2 \%$ & $1 \%$ & $11 \%$ & $3 \% *$ & $4 \%$ & $38 \% *$ & $36 \% *$ & $4 \% *$ & 92 \\
\hline \multirow{2}{*}{ Club 1201} & Baseline & $0 \%$ & $17 \%$ & $35 \%$ & $0 \%$ & $0 \%$ & $22 \%$ & $26 \%$ & $0 \%$ & 23 \\
\hline & Wave 2 & $2 \%$ & $7 \%$ & $7 \% *$ & $3 \%$ & $5 \%$ & $32 \%$ & $37 \%$ & $7 \%$ & 59 \\
\hline \multirow{2}{*}{ Orenco MFH } & Baseline & $0 \%$ & $7 \%$ & $19 \%$ & $0 \%$ & $0 \%$ & $30 \%$ & $44 \%$ & $0 \%$ & 27 \\
\hline & Wave 2 & $0 \%$ & $0 \%$ & $17 \%$ & $3 \%$ & $14 \%$ & $19 \%$ & $44 \%$ & $3 \%$ & 36 \\
\hline \multirow{2}{*}{$\begin{array}{l}\text { Elmonica } \\
\text { Condos }\end{array}$} & Baseline & $0 \%$ & $19 \%$ & $27 \%$ & $0 \%$ & $0 \%$ & $35 \%$ & $19 \%$ & $0 \%$ & 26 \\
\hline & Wave 2 & $0 \%$ & $0 \%$ & $18 \%$ & $7 \%$ & $0 \%$ & $39 \%$ & $36 \%$ & $0 \%$ & 28 \\
\hline \multirow{2}{*}{ Total } & Baseline & $1 \%$ & $8 \%$ & $23 \%$ & $0 \%$ & $5 \%$ & $51 \%$ & $12 \%$ & $0 \%$ & 305 \\
\hline & Wave 2 & $1 \%$ & $3 \% *$ & $15 \% *$ & $3 \% *$ & $7 \%$ & $33 \% *$ & $33 \% *$ & $4 \%$ & 290 \\
\hline
\end{tabular}

*Significant at <.05, Chi-Square

Table 3-7 shows the income categories of respondents, although the categories were not adjusted for inflation. Overall, there was a decrease in each subgroup making less than $\$ 50,000$ per year (though not all significant), and an increase in each subgroup making more than $\$ 50,000$ per year (again, not all significant). Notably, the increase in those making more than $\$ 150,000$ per year was significant, going from 3\% to 13\%. For this change, Orenco MFH saw a significant increase from $4 \%$ to $37 \%$, and Elmonica Condos saw a significant increase from $0 \%$ to $15 \%$. 
Table 3-7 Income

\begin{tabular}{|c|c|c|c|c|c|c|c|c|c|c|}
\hline Building & Survey & $\begin{array}{c}< \\
\$ 15 \\
\mathbf{k}\end{array}$ & $\begin{array}{c}\$ 15- \\
<\$ 25 \\
\mathbf{k}\end{array}$ & $\begin{array}{c}\$ 25- \\
<\$ 35 \\
\mathbf{k}\end{array}$ & $\begin{array}{c}\$ 35- \\
<\$ 50 k\end{array}$ & $\begin{array}{c}\$ 50- \\
<\$ 75 k\end{array}$ & $\begin{array}{c}\$ 75- \\
<\$ 100 k \\
\end{array}$ & $\begin{array}{c}\$ 100- \\
<\$ 150 k\end{array}$ & $\begin{array}{c}> \\
\$ 150 k\end{array}$ & $\mathbf{n}$ \\
\hline \multirow{2}{*}{$\begin{array}{c}\text { East Portland } \\
\text { TODs }\end{array}$} & Baseline & $46 \%$ & $13 \%$ & $13 \%$ & $17 \%$ & $8 \%$ & $0 \%$ & $4 \%$ & $0 \%$ & 24 \\
\hline & Wave 2 & $14 \%$ & $21 \%$ & $7 \%$ & $7 \%$ & $21 \%$ & $14 \%$ & $14 \%$ & $0 \%$ & 14 \\
\hline \multirow{2}{*}{$\begin{array}{c}\text { Gresham } \\
\text { Central }\end{array}$} & Baseline & $6 \%$ & $0 \%$ & $28 \%$ & $39 \%$ & $22 \%$ & $6 \%$ & $0 \%$ & $0 \%$ & 18 \\
\hline & Wave 2 & $7 \%$ & $7 \%$ & $7 \%$ & $13 \%$ & $60 \%$ & $7 \%$ & $0 \%$ & $0 \%$ & 15 \\
\hline \multirow{2}{*}{$\begin{array}{c}\text { Gresham } \\
\text { TODs }\end{array}$} & Baseline & $0 \%$ & $20 \%$ & $13 \%$ & $20 \%$ & $13 \%$ & $20 \%$ & $10 \%$ & $3 \%$ & 30 \\
\hline & Wave 2 & $0 \%$ & $13 \%$ & $10 \%$ & $3 \%$ & $40 \%$ & $20 \%$ & $3 \%$ & $10 \%$ & 30 \\
\hline \multirow{2}{*}{$\begin{array}{l}\text { Beaverton } \\
\text { Round }\end{array}$} & Baseline & $0 \%$ & $0 \%$ & $0 \%$ & $8 \%$ & $23 \%$ & $23 \%$ & $38 \%$ & $8 \%$ & 13 \\
\hline & Wave 2 & $0 \%$ & $0 \%$ & $0 \%$ & $0 \%$ & $6 \%$ & $38 \%$ & $19 \%$ & $38 \%$ & 16 \\
\hline \multirow{2}{*}{$\begin{array}{c}\text { Nexus } \\
\text { Apartments }\end{array}$} & Baseline & $13 \%$ & $5 \%$ & $9 \%$ & $13 \%$ & $23 \%$ & $17 \%$ & $15 \%$ & $4 \%$ & 138 \\
\hline & Wave 2 & $7 \%$ & $1 \%$ & $3 \%$ & $17 \%$ & $24 \%$ & $19 \%$ & $25 \%$ & $3 \%$ & 88 \\
\hline \multirow{2}{*}{ Club 1201} & Baseline & $5 \%$ & $10 \%$ & $19 \%$ & $19 \%$ & $19 \%$ & $14 \%$ & $10 \%$ & $5 \%$ & 21 \\
\hline & Wave 2 & $2 \%$ & $6 \%$ & $6 \%$ & $14 \%$ & $27 \%$ & $6 \%$ & $24 \%$ & $14 \%$ & 49 \\
\hline \multirow{2}{*}{ Orenco MFH } & Baseline & $0 \%$ & $4 \%$ & $7 \%$ & $4 \%$ & $33 \%$ & $30 \%$ & $19 \%$ & $4 \%$ & 27 \\
\hline & Wave 2 & $6 \%$ & $0 \%$ & $9 \%$ & $11 \%$ & $3 \% *$ & $26 \%$ & $9 \%$ & $37 \% *$ & 35 \\
\hline \multirow{2}{*}{$\begin{array}{l}\text { Elmonica } \\
\text { Condos }\end{array}$} & Baseline & $0 \%$ & $4 \%$ & $31 \%$ & $27 \%$ & $23 \%$ & $4 \%$ & $12 \%$ & 0\% & 26 \\
\hline & Wave 2 & $0 \%$ & $0 \%$ & $7 \% *$ & $7 \%$ & $22 \%$ & $33 \% *$ & $15 \%$ & $15 \% *$ & 27 \\
\hline \multirow{2}{*}{ Total } & Baseline & $10 \%$ & $7 \%$ & $13 \%$ & $16 \%$ & $22 \%$ & $15 \%$ & $13 \%$ & $3 \%$ & 297 \\
\hline & Wave 2 & $4 \% *$ & $4 \%$ & $6 \% *$ & $12 \%$ & $24 \%$ & $19 \%$ & $17 \%$ & $13 \% *$ & 274 \\
\hline
\end{tabular}

*Significant at $<.05$, Chi-Square

\section{Inferred Changes in Demographics}

Overall, the survey sample in the second wave includes more women, people who are a bit older, more likely to be retired, higher educated, and earning more money. Some of these changes may be partially related to the decrease in the percentage of respondents who are currently students, as well as the increase in the average age of respondents. The increases in income in a number of west-side TODs may also suggest that these buildings are becoming more popular with employees of some of the larger companies in the vicinity, such as Nike and Intel. 


\section{Overall Findings on Travel Behavior and Attitudes}

Our findings are presented in three chapters. This first chapter presents data on key travel behavior indicators and attitudes, comparing the findings from the baseline survey with the second-wave survey. The next chapter explores whether those changes are correlated with changes in the surrounding neighborhoods. The chapter following that presents findings specific to each TOD.

\section{Transportation Options}

The surveys sought to identify factors that affect the transportation options available to individual respondents, including access to cars and bicycles (see Table 4-1). Overall, the percentage of respondents with a driver's license and the percentage of no-car households remained steady, at about 91\%-93\% and 9\%-11\%, respectively. However, the number of "lowcar households," defined as households with fewer cars than adults, increased from 34\% to 50\%. Interestingly, we also observed that the percentage of respondents with access to a working personal bicycle decreased from $60 \%$ to $46 \%$.

Table 4-1 Percentage of Respondents with Transportation Options

\begin{tabular}{|c|c|c|c|c|c|c|}
\hline Building & Survey & $\begin{array}{c}\text { Has Driver's } \\
\text { License } \\
\end{array}$ & $\begin{array}{c}\text { No-Car } \\
\text { Household }\end{array}$ & $\begin{array}{c}\text { ewer Car } \\
\text { Than } \\
\text { Adults }\end{array}$ & $\begin{array}{c}\text { Has Access to } \\
\text { Bicycle (personal) }\end{array}$ & $\mathbf{n}$ \\
\hline \multirow{2}{*}{$\begin{array}{l}\text { East Portland } \\
\text { TODs }\end{array}$} & Baseline & $77 \%$ & $31 \%$ & $50 \%$ & $50 \%$ & 26 \\
\hline & Wave 2 & $93 \%$ & $19 \%$ & $67 \%$ & $44 \%$ & 15 \\
\hline \multirow{2}{*}{$\begin{array}{l}\text { Gresham } \\
\text { Central }\end{array}$} & Baseline & $88 \%$ & $11 \%$ & $39 \%$ & $100 \%$ & 17 \\
\hline & Wave 2 & $93 \%$ & $19 \%$ & $60 \%$ & $40 \% *$ & 15 \\
\hline \multirow{2}{*}{ Gresham TODs } & Baseline & $100 \%$ & $0 \%$ & $20 \%$ & $80 \%$ & 30 \\
\hline & Wave 2 & $100 \%$ & $3 \%$ & $55 \% *$ & $58 \%$ & 30 \\
\hline \multirow{2}{*}{$\begin{array}{l}\text { Beaverton } \\
\text { Round }\end{array}$} & Baseline & $100 \%$ & $0 \%$ & $15 \%$ & $38 \%$ & 13 \\
\hline & Wave 2 & $100 \%$ & $6 \%$ & $50 \%$ & $53 \%$ & 16 \\
\hline \multirow{2}{*}{$\begin{array}{c}\text { Nexus } \\
\text { Apartments }\end{array}$} & Baseline & $91 \%$ & $10 \%$ & $42 \%$ & $59 \%$ & 139 \\
\hline & Wave 2 & $88 \%$ & $13 \%$ & $54 \%$ & $37 \% *$ & 92 \\
\hline \multirow{2}{*}{ Club 1201} & Baseline & $91 \%$ & $4 \%$ & $22 \%$ & $61 \%$ & 23 \\
\hline & Wave 2 & $90 \%$ & $12 \%$ & $45 \% *$ & $48 \%$ & 59 \\
\hline \multirow{2}{*}{ Orenco MFH } & Baseline & $100 \%$ & $4 \%$ & $33 \%$ & $57 \%$ & 27 \\
\hline & Wave 2 & $94 \%$ & $3 \%$ & $31 \%$ & $64 \%$ & 36 \\
\hline \multirow{2}{*}{$\begin{array}{l}\text { Elmonica } \\
\text { Condos }\end{array}$} & Baseline & $100 \%$ & $0 \%$ & $12 \%$ & $54 \%$ & 25 \\
\hline & Wave 2 & $81 \% *$ & $13 \%$ & $50 \%$ & $33 \%$ & 27 \\
\hline \multirow{2}{*}{ Total } & Baseline & $93 \%$ & $9 \%$ & $34 \%$ & $60 \%$ & 300 \\
\hline & Wave 2 & $91 \%$ & $11 \%$ & $50 \% *$ & $46 \% *$ & 290 \\
\hline
\end{tabular}

*Significant at $<.05$, Chi-Square

Another factor that can influence the use of transportation options on an individual level are physical or anxiety conditions that prevent people from access modes, such as driving a car, 
walking, bicycling or using public transport. We asked respondents if they had such a condition for each of these modes. The percentage indicating they did have such a condition increased in each case, with the percentage of those having a condition preventing them from driving a car going from 5\% to $13 \%$, and those having a condition preventing them from using public transit going from $6 \%$ to $14 \%$. Increases in such conditions for walking and riding a bicycle increased from $6 \%$ to $11 \%$ for walking, and $13 \%$ to $21 \%$ for bicycling, but were not statistically significant.

Table 4-2 Percentage of Respondents with Conditions Preventing a Mode

\begin{tabular}{|c|c|c|c|c|c|c|}
\hline \multirow[b]{2}{*}{ Building } & \multicolumn{6}{|c|}{ Physical or Anxiety Condition: } \\
\hline & Survey & $\begin{array}{c}\text { Driving } \\
\text { a } \\
\text { Vehicle }\end{array}$ & $\begin{array}{c}\text { Walking } \\
\text { Outside the } \\
\text { Home }\end{array}$ & $\begin{array}{c}\text { Riding a } \\
\text { Bicycle }\end{array}$ & $\begin{array}{c}\text { Using Public } \\
\text { Transit } \\
\end{array}$ & $\mathbf{n}$ \\
\hline \multirow{2}{*}{$\begin{array}{l}\text { East Portland } \\
\text { TODs }\end{array}$} & Baseline & $0 \%$ & $4 \%$ & $33 \%$ & $4 \%$ & 24 \\
\hline & Wave 2 & $0 \%$ & $20 \%$ & $13 \%$ & $0 \%$ & 15 \\
\hline \multirow{2}{*}{ Gresham Central } & Baseline & $33 \%$ & $28 \%$ & $33 \%$ & $22 \%$ & 18 \\
\hline & Wave 2 & $7 \%$ & $20 \%$ & $7 \%$ & $20 \%$ & 15 \\
\hline \multirow{2}{*}{ Gresham TODs } & Baseline & $0 \%$ & $3 \%$ & $23 \%$ & $6 \%$ & 31 \\
\hline & Wave 2 & $7 \%$ & $10 \%$ & $43 \%$ & $27 \%$ & 30 \\
\hline \multirow{2}{*}{ Beaverton Round } & Baseline & $8 \%$ & $8 \%$ & $0 \%$ & $0 \%$ & 13 \\
\hline & Wave 2 & $0 \%$ & $6 \%$ & $6 \%$ & $6 \%$ & 16 \\
\hline \multirow{2}{*}{$\begin{array}{c}\text { Nexus } \\
\text { Apartments }\end{array}$} & Baseline & $4 \%$ & $6 \%$ & $10 \%$ & $6 \%$ & 142 \\
\hline & Wave 2 & $19 \%$ & $3 \%$ & $12 \%$ & $14 \%$ & 91 \\
\hline \multirow{2}{*}{ Club 1201} & Baseline & $9 \%$ & $4 \%$ & $9 \%$ & $9 \%$ & 23 \\
\hline & Wave 2 & $14 \%$ & $24 \%$ & $40 \%$ & $22 \%$ & 58 \\
\hline \multirow{2}{*}{ Orenco MFH } & Baseline & $0 \%$ & $0 \%$ & $7 \%$ & $4 \%$ & 27 \\
\hline & Wave 2 & $0 \%$ & $0 \%$ & $8 \%$ & $3 \%$ & 36 \\
\hline \multirow{2}{*}{ Elmonica Condos } & Baseline & $0 \%$ & $4 \%$ & $4 \%$ & $0 \%$ & 26 \\
\hline & Wave 2 & $32 \%$ & $21 \%$ & $25 \%$ & $7 \%$ & 28 \\
\hline \multirow{2}{*}{ Total } & Baseline & $5 \%$ & $6 \%$ & $13 \%$ & $6 \%$ & 304 \\
\hline & Wave 2 & $13 \% *$ & $11 \%$ & $21 \%$ & $14 \% *$ & 289 \\
\hline
\end{tabular}

*Significant at $<.05$, Chi-Square

\section{Travel Behavior}

A key question of the study was whether or not travel behavior of the residents living in these TODs had changed between when the baseline surveys were conducted and the second wave in 2018 and 2019. This section looks first at how people are commuting (for those who work or go to school outside the home), followed by a deeper look at walking, driving and transit behavior.

\section{Commuting}

One question pertained to how often people in the TODs were using various modes of transportation to get to and from work or school. Table 4-3 speaks to that question by showing the percentage of people, of those who work or go to school outside their homes, reported 
commuting at least once per week by driving alone, by transit, or by active transportation modes such as walking and bicycling.

Overall, we did not observe significant changes between the baseline and second-wave surveys for driving alone and transit commute trips. The former going from $74 \%$ of respondents driving at least once per week to $68 \%$ - not a statistically significant drop; while the latter dropped from $34 \%$ to $31 \%$ - again, not a significant drop. However, there were a couple of significant differences for individual buildings for these modes. For the Gresham TOD group, the percentage of commuters driving alone at least once per week dropped from $95 \%$ to $67 \%$, which was significant. The increases in commute by transit and active transportation for this group, both of which increased from $5 \%$ to $28 \%$, though not significant, do suggest that these people were shifting away from driving to other modes for commute trips. Meanwhile, the Orenco MFH respondents showed a dramatic drop in the percentage of respondents commuting by transit at least once per week, dropping from $53 \%$ to $12 \%$.

The biggest change that we observed for commute trips concerns the percentage of respondents who reported commuting by walking or bicycling at least once per week - jumping from $9 \%$ to $29 \%$. In fact, there were major increases in this area for nearly every building.

Table 4-3 Commuting at Least Once per Week by Select Modes, for Those who Work Outside the Home

\begin{tabular}{cccccc} 
Building & Survey & $\begin{array}{c}\text { Commute by } \\
\text { Driving Alone at } \\
\text { Least Once per } \\
\text { Week }\end{array}$ & $\begin{array}{c}\text { Commute by } \\
\text { Transit at } \\
\text { Least Once } \\
\text { per Week }\end{array}$ & $\begin{array}{c}\text { Commute by Walk } \\
\text { or Bike at least } \\
\text { once per week }\end{array}$ & n \\
\hline $\begin{array}{c}\text { East Portland } \\
\text { TODs }\end{array}$ & Baseline & $85 \%$ & $46 \%$ & $15 \%$ & 13 \\
\hline Gresham & Wave 2 & $58 \%$ & $58 \%$ & $50 \%$ & 12 \\
Central & Baseline & $77 \%$ & $31 \%$ & $0 \%$ & 13 \\
\hline Gresham & Bave 2 & $83 \%$ & $25 \%$ & $25 \%$ & 12 \\
TODs & Wave 2 & $\mathbf{9 5 \%}$ & $5 \%$ & $5 \%$ & 19 \\
Beaverton & Baseline & $\mathbf{6 7 \% *}$ & $28 \%$ & $28 \%$ & 18 \\
Round & Wave 2 & $85 \%$ & $42 \%$ & $8 \%$ & 12 \\
\hline Nexus & Baseline & $67 \%$ & $50 \%$ & $36 \%$ & 14 \\
Apartments & Wave 2 & $60 \%$ & $37 \%$ & $\mathbf{1 0 \%}$ & 106 \\
\hline \multirow{2}{*}{ Club 1201 } & Baseline & $71 \%$ & $29 \%$ & $\mathbf{3 5 \% *}$ & 75 \\
\hline \multirow{2}{*}{ Orenco MFH } & Wave 2 & $66 \%$ & $29 \%$ & $18 \%$ & 17 \\
\hline Elmonica & Baseline & $63 \%$ & $31 \%$ & $17 \%$ & 29 \\
\hline Condos & Wave 2 & $76 \%$ & $\mathbf{5 3 \%}$ & $5 \%$ & 19 \\
\hline \multirow{2}{*}{ Total } & Baseline & $92 \%$ & $21 \%$ & $25 \%$ & 17 \\
\hline & Wave 2 & $76 \%$ & $29 \%$ & $\mathbf{0 \%}$ & 24 \\
\hline
\end{tabular}

*Significant at $<.05$, Chi-Square 
We do see an overall significant reduction in driving alone to work or school on a frequent basis. Table 4-4 shows the percentage of respondents who, among those who commute to work or school, do so via driving alone by frequency. The overall percentage of those who do so four to five days a week dropped from $58 \%$ to $46 \%$, while the overall percentage of those who never commute by driving alone increased from $11 \%$ to $24 \%$. Notably, all of the sites on the east side of Portland (East Portland TODs, Gresham Central, and Gresham TODs group) all decreased from $61-69 \%$ of respondents commuting by driving alone four to five days per week to less than half.

Table 4-4 Average Days per Week Commuting by Driving Alone, for Those who Work Outside the Home

\begin{tabular}{|c|c|c|c|c|c|c|c|c|}
\hline Building & Survey & $\begin{array}{c}4-5 \\
\text { Days } \\
\text { per } \\
\text { Week }\end{array}$ & $\begin{array}{c}2-3 \\
\text { Days } \\
\text { per } \\
\text { Week }\end{array}$ & $\begin{array}{c}\text { Once } \\
\text { a } \\
\text { Week }\end{array}$ & $\begin{array}{c}1-3 \\
\text { Days a } \\
\text { Month }\end{array}$ & $\begin{array}{c}\text { Less than } \\
\text { Once a } \\
\text { Month }\end{array}$ & Never & $\mathbf{n}$ \\
\hline \multirow{2}{*}{$\begin{array}{l}\text { East Portland } \\
\text { TODs }\end{array}$} & Baseline & $67 \%$ & $17 \%$ & $8 \%$ & $0 \%$ & $0 \%$ & $8 \%$ & 12 \\
\hline & Wave 2 & $33 \%$ & $17 \%$ & $8 \%$ & $8 \%$ & $0 \%$ & $33 \%$ & 12 \\
\hline \multirow{2}{*}{$\begin{array}{c}\text { Gresham } \\
\text { Central }\end{array}$} & Baseline & $69 \%$ & $0 \%$ & $8 \%$ & $0 \%$ & $0 \%$ & $23 \%$ & 13 \\
\hline & Wave 2 & $42 \%$ & $17 \%$ & $25 \%$ & $8 \%$ & $0 \%$ & $8 \%$ & 12 \\
\hline \multirow{2}{*}{$\begin{array}{c}\text { Gresham } \\
\text { TODs }\end{array}$} & Baseline & $61 \%$ & $33 \%$ & $6 \%$ & $0 \%$ & $0 \%$ & $0 \%$ & 18 \\
\hline & Wave 2 & $47 \%$ & $18 \%$ & $6 \%$ & $6 \%$ & $6 \%$ & $18 \%$ & 17 \\
\hline \multirow{2}{*}{$\begin{array}{c}\text { Beaverton } \\
\text { Round }\end{array}$} & Baseline & $55 \%$ & $18 \%$ & $9 \%$ & $0 \%$ & $0 \%$ & $18 \%$ & 11 \\
\hline & Wave 2 & $43 \%$ & $21 \%$ & $21 \%$ & $0 \%$ & $0 \%$ & $14 \%$ & 14 \\
\hline \multirow{2}{*}{$\begin{array}{c}\text { Nexus } \\
\text { Apartments }\end{array}$} & Baseline & $59 \%$ & $10 \%$ & $8 \%$ & $8 \%$ & $4 \%$ & $12 \%$ & 93 \\
\hline & Wave 2 & $45 \%$ & $15 \%$ & $1 \%$ & $5 \%$ & $3 \%$ & $31 \%$ & 74 \\
\hline \multirow{2}{*}{ Club 1201} & Baseline & $41 \%$ & $18 \%$ & $12 \%$ & $6 \%$ & $0 \%$ & $24 \%$ & 17 \\
\hline & Wave 2 & $38 \%$ & $17 \%$ & $10 \%$ & $0 \%$ & $7 \%$ & $28 \%$ & 29 \\
\hline \multirow{2}{*}{ Orenco MFH } & Baseline & $39 \%$ & $22 \%$ & $6 \%$ & $11 \%$ & $17 \%$ & $6 \%$ & 18 \\
\hline & Wave 2 & $44 \%$ & $25 \%$ & $13 \%$ & $6 \%$ & $6 \%$ & $6 \%$ & 16 \\
\hline \multirow{2}{*}{$\begin{array}{c}\text { Elmonica } \\
\text { Condos }\end{array}$} & Baseline & $67 \%$ & $13 \%$ & $13 \%$ & $0 \%$ & $4 \%$ & $4 \%$ & 24 \\
\hline & Wave 2 & $71 \%$ & $5 \%$ & $0 \%$ & $0 \%$ & $5 \%$ & $19 \%$ & 21 \\
\hline \multirow{2}{*}{ Total } & Baseline & $58 \%$ & $14 \%$ & $8 \%$ & $5 \%$ & $4 \%$ & $11 \%$ & 206 \\
\hline & Wave 2 & $46 \% *$ & $16 \%$ & $7 \%$ & $4 \%$ & $4 \%$ & $24 \% *$ & 195 \\
\hline
\end{tabular}

*Significant at $<.05$, Chi-Square 
In terms of commuting by transit, the percentage of respondents who never do so increased from $49 \%$ to $56 \%$, which was not a significant difference (Table 4-5). Although not significant, the Gresham TODs group did see an increase in those who commute by transit at least occasionally, increasing from 9\% to 37\%. Meanwhile, the Orenco MFH group saw that number drop from $63 \%$ commuting by transit at least occasionally to only $19 \%$.

Table 4-5 Average Days per Week Commuting by MAX, for Those who Work Outside the Home

\begin{tabular}{|c|c|c|c|c|c|c|c|c|}
\hline Building & Survey & $\begin{array}{c}4-5 \\
\text { Days } \\
\text { per } \\
\text { Week }\end{array}$ & $\begin{array}{c}2-3 \\
\text { Days } \\
\text { per } \\
\text { Week }\end{array}$ & $\begin{array}{c}\text { Once a } \\
\text { Week }\end{array}$ & $\begin{array}{c}1-3 \\
\text { Days a } \\
\text { Month }\end{array}$ & $\begin{array}{c}\text { Less } \\
\text { than } \\
\text { Once a } \\
\text { Month }\end{array}$ & Never & $\mathbf{n}$ \\
\hline \multirow{2}{*}{$\begin{array}{l}\text { East Portland } \\
\text { TODs }\end{array}$} & Baseline & $17 \%$ & $25 \%$ & $0 \%$ & $0 \%$ & $33 \%$ & $25 \%$ & 12 \\
\hline & Wave 2 & $27 \%$ & $27 \%$ & $9 \%$ & $9 \%$ & $0 \%$ & $27 \%$ & 11 \\
\hline \multirow{2}{*}{$\begin{array}{c}\text { Gresham } \\
\text { Central }\end{array}$} & Baseline & $25 \%$ & $13 \%$ & $0 \%$ & $0 \%$ & $13 \%$ & $50 \%$ & 8 \\
\hline & Wave 2 & $17 \%$ & $0 \%$ & $0 \%$ & $8 \%$ & $17 \%$ & $58 \%$ & 12 \\
\hline \multirow{2}{*}{ Gresham TODs } & Baseline & $0 \%$ & $9 \%$ & $0 \%$ & $0 \%$ & $0 \%$ & $91 \%$ & 11 \\
\hline & Wave 2 & $19 \%$ & $6 \%$ & $0 \%$ & $6 \%$ & $6 \%$ & $63 \%$ & 16 \\
\hline \multirow{2}{*}{$\begin{array}{c}\text { Beaverton } \\
\text { Round }\end{array}$} & Baseline & $33 \%$ & $8 \%$ & $0 \%$ & $0 \%$ & $17 \%$ & $42 \%$ & 12 \\
\hline & Wave 2 & $14 \%$ & $21 \%$ & $14 \%$ & $14 \%$ & $0 \%$ & $36 \%$ & 14 \\
\hline \multirow{2}{*}{$\begin{array}{c}\text { Nexus } \\
\text { Apartments }\end{array}$} & Baseline & $28 \%$ & $10 \%$ & $1 \%$ & $3 \%$ & $11 \%$ & $46 \%$ & 97 \\
\hline & Wave 2 & $15 \%$ & $11 \%$ & $1 \%$ & $4 \%$ & $8 \%$ & $59 \%$ & 71 \\
\hline \multirow{2}{*}{ Club 1201} & Baseline & $6 \%$ & $12 \%$ & $12 \%$ & $0 \%$ & $24 \%$ & $47 \%$ & 17 \\
\hline & Wave 2 & $24 \%$ & $8 \%$ & $4 \%$ & $0 \%$ & $12 \%$ & $52 \%$ & 25 \\
\hline \multirow{2}{*}{ Orenco MFH } & Baseline & $26 \%$ & $21 \%$ & $0 \%$ & $5 \%$ & $11 \%$ & $37 \%$ & 19 \\
\hline & Wave 2 & $0 \%$ & $13 \%$ & $0 \%$ & $0 \%$ & $6 \%$ & $81 \%$ & 16 \\
\hline \multirow{2}{*}{$\begin{array}{l}\text { Elmonica } \\
\text { Condos }\end{array}$} & Baseline & $13 \%$ & $8 \%$ & $0 \%$ & $4 \%$ & $8 \%$ & $67 \%$ & 24 \\
\hline & Wave 2 & $24 \%$ & $5 \%$ & $0 \%$ & $10 \%$ & $10 \%$ & $52 \%$ & 21 \\
\hline \multirow{2}{*}{ Total } & Baseline & $22 \%$ & $12 \%$ & $2 \%$ & $3 \%$ & $13 \%$ & $49 \%$ & 200 \\
\hline & Wave 2 & $17 \%$ & $11 \%$ & $3 \%$ & $5 \%$ & $8 \%$ & $56 \%$ & 186 \\
\hline
\end{tabular}

The reduction in driving alone to work most days of the week does not appear to be part of a larger regional trend. The estimates of the share of workers commuting by driving alone in the four cities included in our research is shown in Figure 4-1 for 2005, 2010, and 2018. The data are not directly comparable because of a difference in question wording. The American Community Survey (ACS), from which the city-level data come, asks about the respondents' usual commute mode. Our survey asked how many days a week the respondent used each mode. But while the numbers are not directly comparable, the trends over time within each data source may be compared. The citywide data do not show similar large drops in the share of workers driving alone. There are small reductions over time in Beaverton and Portland, an increase in Gresham, and a mixed trend in Hillsboro. 


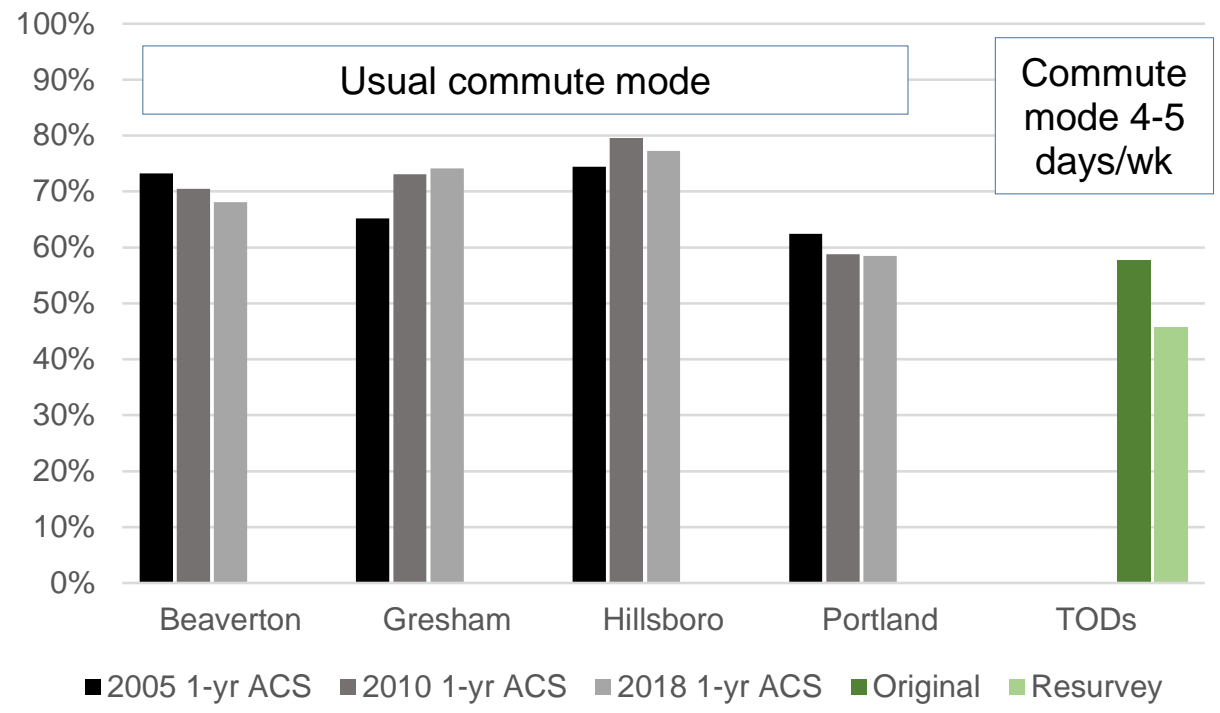

Figure 4-1 Commuting by drive alone, city residents vs. TOD respondents

\section{Walking and Bicycling}

Several sections of the survey asked about walking and bicycling for non-commute purposes, including travel to local shops and services, as well as for trips without destinations, such as walking a dog.

Respondents were asked how many times in the past 30 days they had taken a walk, jog or stroll around the neighborhood (such as for exercise or to walk a dog), as well as how many times they had walked from their home to a business or store in the neighborhood. We hypothesized that the latter type of trip in particular might have increased as the TOD neighborhoods developed over time. In fact, we did not observe significant changes in the number of such walk trips for either the casual walks around the neighborhood or the walks to business or stores (see Table 4-6 for the mean number of trips for each building/group). One building, Gresham Central, showed a significant increase in casual walks, from an average of 6.8 walks in the past 30 days to 18.3 walks. Overall, these casual walks increased from 13.3 to 15.5, which was not significant. For walks to businesses or stores, there were no significant differences for any of the buildings, and the overall average barely moved, from 7.96 to 8.04 . 
Table 4-6 Walking in Neighborhood

\begin{tabular}{ccccccc}
\hline & \multicolumn{2}{c}{$\begin{array}{c}\text { \# of Walk, Jog, or Stroll } \\
\text { Around Neighborhood in } \\
\text { Past 30 Days }\end{array}$} & \multicolumn{2}{c}{$\begin{array}{c}\text { \# of Walk from Home to a } \\
\text { Business or Store in the } \\
\text { Neighborhood in Past 30 Days }\end{array}$} & \multicolumn{2}{c}{ n } \\
& $\begin{array}{c}\text { Baseline } \\
\text { Wave 2 }\end{array}$ & $\begin{array}{c}\text { Baseline } \\
\text { Wave 2 }\end{array}$ & Baseline & Wave 2 \\
\hline East Portland TODs & 6.9 & 11.5 & 6.7 & 7.1 & 24 & 15 \\
Gresham Central & $\mathbf{6 . 8}$ & $\mathbf{1 8 . 3 *}$ & 5.9 & 6.1 & 17 & 16 \\
Gresham TODs & 12.6 & 16.2 & 11.7 & 8.8 & 31 & 31 \\
Beaverton Round & 2.9 & 7.7 & 2.4 & 5.6 & 13 & 15 \\
Nexus Apartments & 15.1 & 17.8 & 8.0 & 9.0 & 140 & $97 ; 98$ \\
Club 1201 & 13.3 & 12.9 & 8.0 & 7.0 & 22 & $57 ; 59$ \\
Orenco MFH & 22.2 & 23.9 & 14.6 & 14.0 & 28 & 36 \\
Elmonica Condos & 10.0 & 6.0 & 1.5 & 1.8 & 25 & 29 \\
\hline Total & 13.3 & 15.5 & 8.0 & 8.0 & 300 & $296 ;$ \\
\hline
\end{tabular}

*Significant at $<.05$, independent samples t-test

Another section asked respondents how often they walk or bike to certain specific types of destinations, such as restaurant or bars, stores, parks, and other places. The percentage of respondents in each building that walk or bike to each destination type at least once per week are shown in Table 4-7 for restaurants, stores, and parks, and in Table 4-8 for trips with no particular destination, visits to friends or family, and for entertainment-type trips. We saw few significant differences between the baseline and second-wave surveys. In the second-wave survey period, the trips to restaurants and stores were taken at least once per week by about $41 \%$ of respondents. Parks and trips with no particular destination were close behind with about 39\% and 37\% of respondents saying they take such trips at least once per week. Visits to family and friends and trips for entertainment were farther back, with only $14 \%$ and $4 \%$, respectively, of respondents taking such trips.

For trips to restaurants, bars or cafés, two TOD groups showed significant changes, with the East Portland TODs showing an increase from 13\% to 53\% of respondents who had walked or biked to such a destination at least once per week. The Gresham TODs, on the other hand, showed a significant decrease from $61 \%$ to $33 \%$ of respondents walking or biking to such a destination at least once per week. Gresham Central and Nexus apartments showed increases of 26 and 8 percentage points, respectively, but these differences were not significant.

For trips to stores or places to shop, there were no significant changes; however, several buildings did show considerable changes that did not quite meet a statistically significant level. For example, Beaverton Round increased from $15 \%$ to $38 \%$ of respondents indicating that they took walk or bike trips to stores at least once a week. In contrast, Gresham TODs and Club 1201 both showed decreases in these areas of $25 \%$ and $13 \%$, respectively.

For walk or bike trips to parks or natural open spaces, the overall percentage of respondents making such trips at least once a week increased from 33\% to 39\%, which was not a statistically 
significant change. Individual buildings did show increases, though none were significant. Gresham Central went from 25\% to 50\% of respondents making such trips at least once a week, while Beaverton Round increased from $23 \%$ to $44 \%$.

Table 4-7 Percentage of Respondents who Walk or Bike at Least Once per Week to Select Destinations

\begin{tabular}{|c|c|c|c|c|c|}
\hline \multirow[b]{2}{*}{ Building } & \multirow[b]{2}{*}{ Survey } & \multicolumn{3}{|c|}{$\begin{array}{c}\text { 1x per Week or More: Typical Month - Walk or } \\
\text { Bike: }\end{array}$} & \multirow[b]{2}{*}{ n range } \\
\hline & & $\begin{array}{l}\text { Restaurant, } \\
\text { Bar, or Coffee } \\
\text { Place }\end{array}$ & $\begin{array}{l}\text { Store or Place } \\
\text { to Shop }\end{array}$ & $\begin{array}{l}\text { Park or Natural } \\
\text { Open Space }\end{array}$ & \\
\hline \multirow{2}{*}{ East Portland TODs } & Baseline & $13 \%$ & $40 \%$ & $32 \%$ & $23-25$ \\
\hline & Wave 2 & $53 \% *$ & $40 \%$ & $21 \%$ & $14-15$ \\
\hline \multirow{2}{*}{ Gresham Central } & Baseline & $18 \%$ & $18 \%$ & $25 \%$ & $16-17$ \\
\hline & Wave 2 & $44 \%$ & $25 \%$ & $50 \%$ & 16 \\
\hline \multirow{2}{*}{ Gresham TODs } & Baseline & $61 \%$ & $48 \%$ & $36 \%$ & $27-31$ \\
\hline & Wave 2 & $33 \% *$ & $23 \%$ & $34 \%$ & $29-30$ \\
\hline \multirow{2}{*}{ Beaverton Round } & Baseline & $38 \%$ & $15 \%$ & $23 \%$ & 13 \\
\hline & Wave 2 & $38 \%$ & $38 \%$ & $44 \%$ & 16 \\
\hline \multirow{2}{*}{ Nexus Apartments } & Baseline & $36 \%$ & $44 \%$ & $32 \%$ & $132-139$ \\
\hline & Wave 2 & $44 \%$ & $49 \%$ & $40 \%$ & $95-97$ \\
\hline \multirow{2}{*}{ Club 1201} & Baseline & $39 \%$ & $52 \%$ & $39 \%$ & 23 \\
\hline & Wave 2 & $43 \%$ & $39 \%$ & $31 \%$ & $55-58$ \\
\hline \multirow{2}{*}{ Orenco MFH } & Baseline & $54 \%$ & $79 \%$ & $50 \%$ & 28 \\
\hline & Wave 2 & $51 \%$ & $71 \%$ & $57 \%$ & 35 \\
\hline \multirow{2}{*}{ Elmonica Condos } & Baseline & $15 \%$ & $15 \%$ & $19 \%$ & 26 \\
\hline & Wave 2 & $14 \%$ & $8 \%$ & $32 \%$ & $26-29$ \\
\hline \multirow{2}{*}{ Total } & Baseline & $36 \%$ & $43 \%$ & $33 \%$ & $291-300$ \\
\hline & Wave 2 & $41 \%$ & $41 \%$ & $39 \%$ & $289-296$ \\
\hline
\end{tabular}

*Significant at $<.05$, Chi-Square

Trips out of the house with no particular destination might be comparable to the exercise or dog walking trips discussed above, although in Table 4-8 bike trips are included. There were no significant changes in the percentage of respondents making such trips at least once per week, although a number of buildings did not have non-significant decreases, including the Gresham TODs group going from 59\% of respondents to 39\% of respondents making such trips at least once per week.

For walk or bike trips to visit friends or family, the overall rates did not change, though some buildings did show change between the baseline and the second wave. The East Portland TODs group went from 32\% to 7\%, while the Orenco MFH group went from 14\% to 31\% - the former was a significant difference while the latter was not. 
Finally, walk or bike trips for entertainment purposes were much less likely to be taken by respondents, with only $6 \%$ in the baseline surveys and $4 \%$ in the second wave indicating that they took such trips at least once per week.

Table 4-8 Percentage of Respondents who Walk or Bike at Least Once per Week to Select Destinations

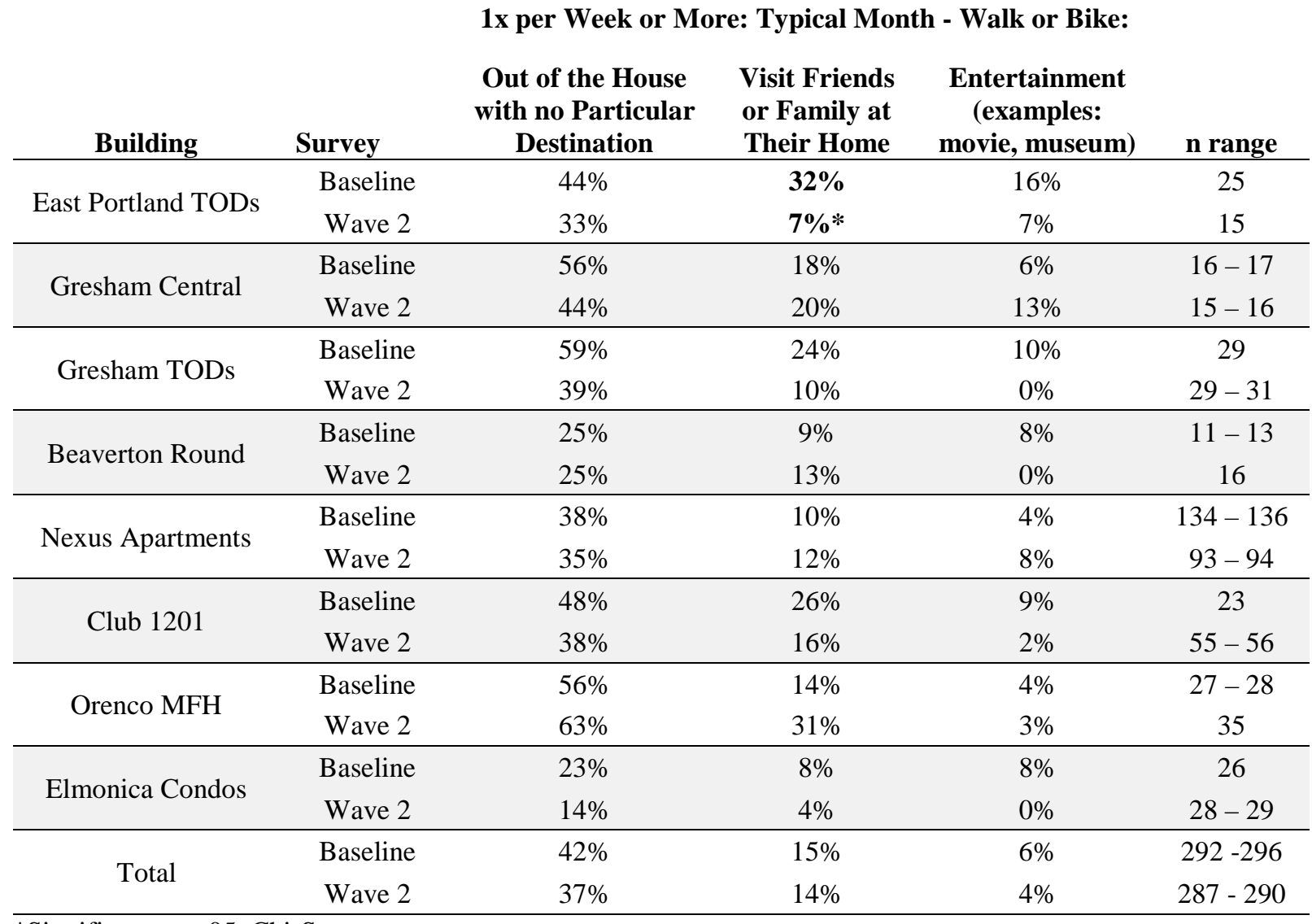

*Significant at $<.05$, Chi-Square

\section{Driving}

Several questions lend insight into the driving habits of survey respondents, including a question asking how many miles they drove in a typical week (including weekends). The overall mean and median miles driven per week did not change by a significant amount (Table 4-9). However, Beaverton Round and Elmonica Condos did exhibit significant drops, from 125 to 70 and 156 to 74 miles per week, respectively. Gresham Central, Gresham TODs, Club 1201 all showed large, but not statistically significant decreases in miles driven per week.

Table 4-9 Estimated Miles Driven per Week

\begin{tabular}{cccccc} 
Building & Survey & Mean & Median & n & Std. Deviation \\
\hline \multirow{2}{*}{ East Portland TODs } & Baseline & 51 & 33 & 24 & 59.3 \\
& Wave 2 & 46 & 28 & 14 & 65.4 \\
\hline
\end{tabular}




\begin{tabular}{cccccc} 
Building & Survey & Mean & Median & n & Std. Deviation \\
\multirow{2}{*}{ Gresham Central } & Baseline & 121 & 70 & 17 & 128.9 \\
& Wave 2 & 92 & 40 & 15 & 103.3 \\
\hline \multirow{2}{*}{ Gresham TODs } & Baseline & 93 & 50 & 29 & 97.8 \\
& Wave 2 & 64 & 50 & 29 & 68.4 \\
\hline \multirow{2}{*}{ Beaverton Round } & Baseline & $\mathbf{1 2 5}$ & 115 & 13 & 71.2 \\
& Wave 2 & $\mathbf{7 0 *}$ & 50 & 15 & 66.2 \\
\hline \multirow{2}{*}{ Nexus Apartments } & Baseline & 78 & 50 & 139 & 90.8 \\
& Wave 2 & 65 & 40 & 88 & 75.2 \\
\hline \multirow{2}{*}{ Club 1201 } & Baseline & 157 & 100 & 23 & 146.7 \\
& Wave 2 & 116 & 78 & 56 & 139.4 \\
\hline \multirow{2}{*}{ Orenco MFH } & Baseline & 98 & 65 & 27 & 91.8 \\
& Wave 2 & 111 & 100 & 36 & 83.6 \\
\hline \multirow{2}{*}{ Elmonica Condos } & Baseline & $\mathbf{1 5 6}$ & 145 & 26 & 133.0 \\
& Wave 2 & $\mathbf{7 4 *}$ & 50 & 28 & 68.2 \\
\hline \multirow{2}{*}{ Total } & Baseline & 96 & 50 & 298 & 104.5 \\
& Wave 2 & 83 & 50 & 281 & 94.2 \\
\hline
\end{tabular}

*Significant at $<.05$, independent samples t-test

\section{Transit}

We asked respondents how frequently they took transit to certain non-work destinations, including the same destinations discussed above for the walk or bike trips (e.g., to a restaurant, store, park, visiting family, and entertainment). We also asked about the frequency with which they take transit to work or school for those who commute to a place outside the home.

Overall, the use of transit to access non-work destinations was quite low, and no significant differences were observed between the baseline and second-wave surveys (Table 4-10). Visits to a store or place to shop were the most common, with 10 to $11 \%$ of respondents making such trips at least once per week. Beaverton Round saw a decrease in transit trips to a variety of destinations, though none of the decreases were significant.

Table 4-10 Percentage of Respondents who Take Transit at Least Once per Week to Select Destinations

\begin{tabular}{|c|c|c|c|c|c|c|c|}
\hline Building & Survey & $\begin{array}{c}\text { 1x per Weel } \\
\text { Restaurant, } \\
\text { Bar, or } \\
\text { Coffee Place } \\
\end{array}$ & $\begin{array}{l}\text { More: T } \\
\text { Store or } \\
\text { Place to } \\
\text { Shop } \\
\end{array}$ & $\begin{array}{c}\text { pical Month } \\
\text { Park or } \\
\text { Natural } \\
\text { Open Space } \\
\end{array}$ & $\begin{array}{c}\text { Take Traı } \\
\text { Visit } \\
\text { Friends } \\
\text { or Family }\end{array}$ & $\begin{array}{l}\text { t: } \\
\text { Entertainmen } \\
\text { t (e.g., movie, } \\
\text { museum) }\end{array}$ & $n$ range \\
\hline \multirow{2}{*}{$\begin{array}{c}\text { East Portland } \\
\text { TODs }\end{array}$} & Baseline & $13 \%$ & $20 \%$ & $17 \%$ & $17 \%$ & $12 \%$ & $24-25$ \\
\hline & Wave 2 & $33 \%$ & $33 \%$ & $13 \%$ & $13 \%$ & $13 \%$ & 15 \\
\hline \multirow{2}{*}{$\begin{array}{c}\text { Gresham } \\
\text { Central }\end{array}$} & Baseline & $13 \%$ & $13 \%$ & $6 \%$ & $6 \%$ & $6 \%$ & $15-17$ \\
\hline & Wave 2 & $13 \%$ & $20 \%$ & $0 \%$ & $7 \%$ & $0 \%$ & 15 \\
\hline \multirow{2}{*}{ Gresham TODs } & Baseline & $0 \%$ & $0 \%$ & $3 \%$ & $0 \%$ & $3 \%$ & 31 \\
\hline & Wave 2 & $7 \%$ & $7 \%$ & $3 \%$ & $3 \%$ & $3 \%$ & 30 \\
\hline
\end{tabular}




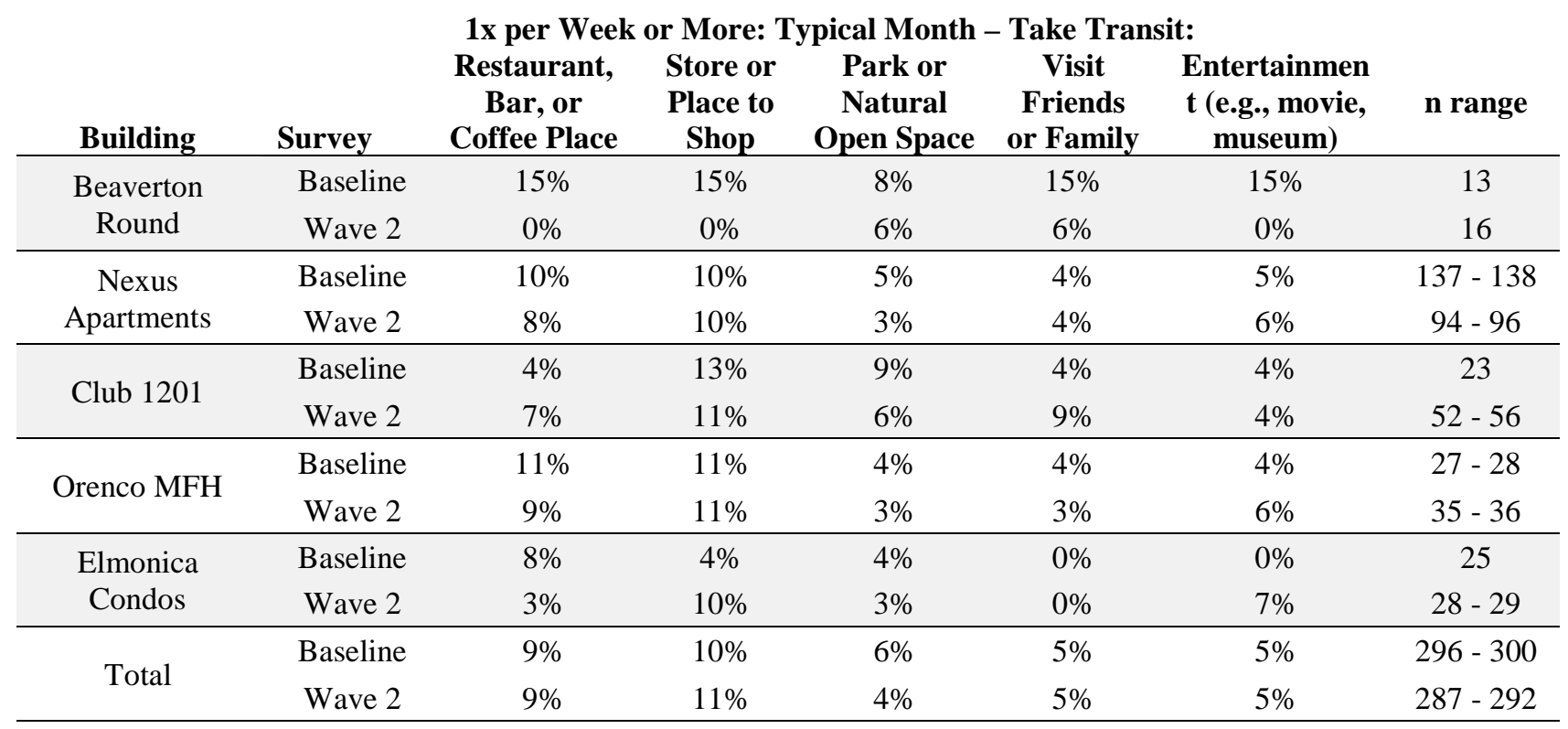

\section{Changes in Travel Behavior after Moving to TOD}

The surveys asked respondents about changes in their travel behavior since moving: "How much do you drive now, compared to when you lived at your previous residence?” The response options were a lot less now, a little less now, about the same, a little more now, and a lot more now. Overall, large shares (about half) of the surveyed TOD residents report that they are driving less (a little or a lot), and using transit and walking more (a little or a lot) (Table 4-11). Smaller shares said they are riding a bike more often. Overall, there were no significant differences in responses to these questions between the baseline and second wave surveys.

We also analyzed these questions based on how long the respondents had lived in their current home (in the TOD). One hypothesis is that people who live in a TOD longer may be more likely to change their travel behavior, as they become more familiar with the neighborhood and travel options and/or as the travel options improve in the neighborhood. We did not see any evidence to support this hypothesis (Figure 4-2). The responses to these questions did not vary significantly based on the number of years living in the home or between the baseline and second-wave surveys.

Table 4-11 Self-reported Changes in Travel Behavior since Moving to Current Home

\begin{tabular}{|c|c|c|c|c|c|c|}
\hline Building & Survey & Drives Less & $\begin{array}{c}\text { Uses Transit } \\
\text { More }\end{array}$ & Walks More & Bikes More & $n$ range \\
\hline \multirow{2}{*}{$\begin{array}{l}\text { East Portland } \\
\text { TODs }\end{array}$} & Baseline & $64 \%$ & $46 \%$ & $38 \%$ & $13 \%$ & $23-26$ \\
\hline & Wave 2 & $47 \%$ & $47 \%$ & $33 \%$ & $27 \%$ & 15 \\
\hline \multirow{2}{*}{$\begin{array}{c}\text { Gresham } \\
\text { Central }\end{array}$} & Baseline & $50 \%$ & $25 \%$ & $65 \%$ & $25 \%$ & $12-17$ \\
\hline & Wave 2 & $31 \%$ & $44 \%$ & $69 \%$ & $19 \%$ & 16 \\
\hline \multirow{2}{*}{$\begin{array}{l}\text { Gresham } \\
\text { TODs }\end{array}$} & Baseline & $77 \%$ & $32 \%$ & $65 \%$ & $27 \%$ & $26-31$ \\
\hline & Wave 2 & $61 \%$ & $34 \%$ & $61 \%$ & $17 \%$ & $29-31$ \\
\hline
\end{tabular}




\begin{tabular}{ccccccc} 
Building & Survey & Drives Less & $\begin{array}{c}\text { Uses Transit } \\
\text { More }\end{array}$ & Walks More & Bikes More & n range \\
\hline Beaverton & Baseline & $77 \%$ & $77 \%$ & $15 \%$ & $20 \%$ & $10-13$ \\
Round & Wave 2 & $56 \%$ & $63 \%$ & $44 \%$ & $33 \%$ & $15-16$ \\
\hline Nexus & Baseline & $51 \%$ & $55 \%$ & $52 \%$ & $20 \%$ & $124-141$ \\
Apartments & Wave 2 & $54 \%$ & $43 \%$ & $56 \%$ & $17 \%$ & $95-96$ \\
\hline \multirow{2}{*}{ Club 1201 } & Baseline & $52 \%$ & $52 \%$ & $48 \%$ & $\mathbf{3 3 \%}$ & $18-23$ \\
& Wave 2 & $61 \%$ & $53 \%$ & $61 \%$ & $\mathbf{1 2 \%}$ & $52-57$ \\
\hline \multirow{2}{*}{ Orenco MFH } & Baseline & $75 \%$ & $74 \%$ & $71 \%$ & $24 \%$ & $21-28$ \\
& Wave 2 & $75 \%$ & $58 \%$ & $61 \%$ & $24 \%$ & $34-36$ \\
\hline \multirow{2}{*}{ Elmonica } & Baseline & $48 \%$ & $60 \%$ & $32 \%$ & $0 \%$ & $23-25$ \\
Condos & Wave 2 & $25 \%$ & $52 \%$ & $17 \%$ & $4 \%$ & $28-29$ \\
\hline \multirow{2}{*}{ Total } & Baseline & $58 \%$ & $53 \%$ & $51 \%$ & $20 \%$ & $257-304$ \\
& Wave 2 & $54 \%$ & $48 \%$ & $53 \%$ & $17 \%$ & $285-295$ \\
\hline
\end{tabular}

*Significant at $<.05$, Chi-Square
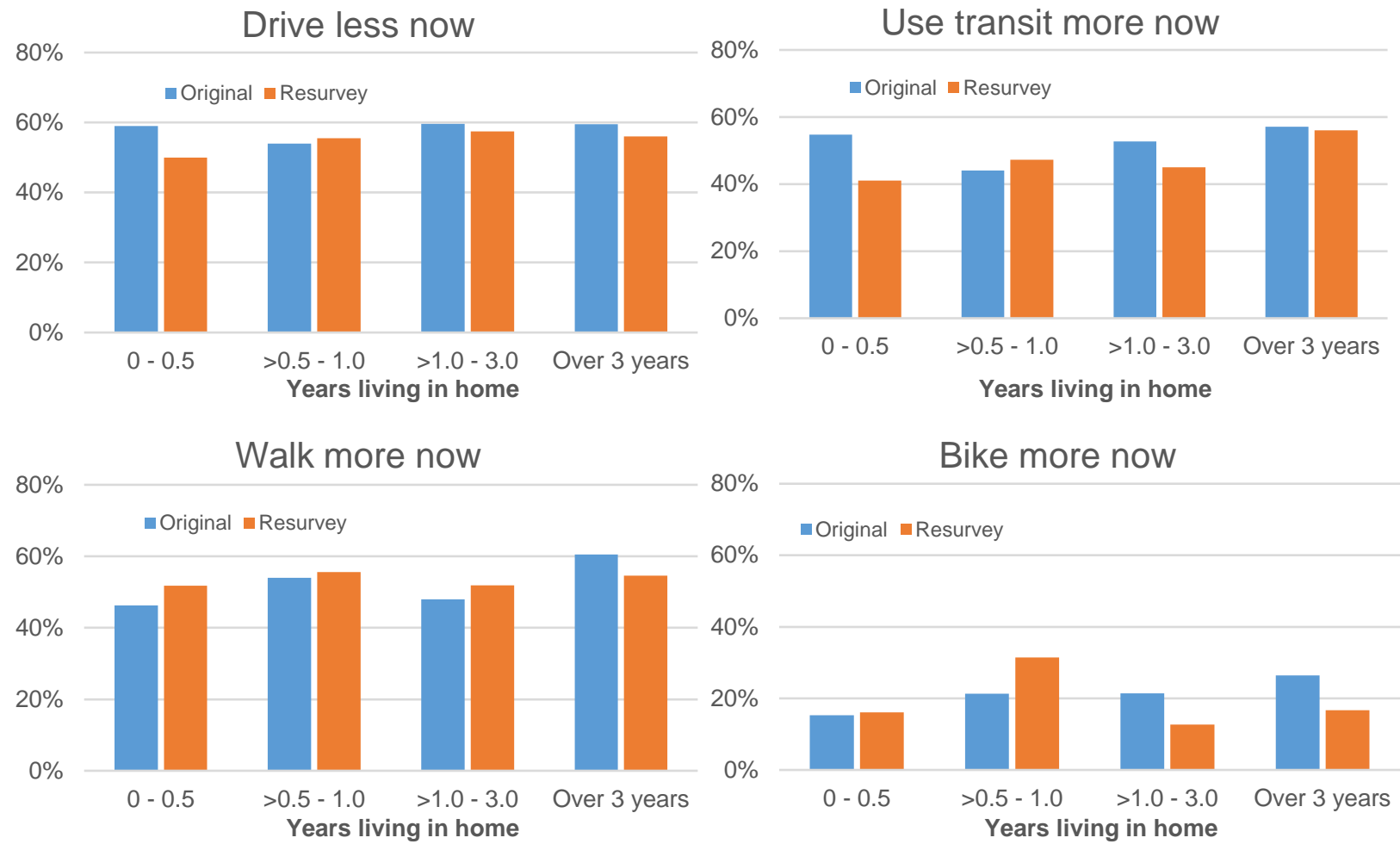

Figure 4-1 Self-reported Changes in Travel Behavior since Moving to Current Home by Length of Residence 


\section{Attitudes}

Respondent attitudes toward their neighborhood and transportation are important considerations in understanding their travel choices. One question asked respondents to indicate "How well do you think your residence and its location meet the current needs of your household?,” with a response scale ranging from very poorly, poorly, neither poorly nor well, well, to very well. Table 4-12 provides the percentage of respondents who answered that the residence meets their needs (i.e., either "well” or "very well” on the scale), by building and survey time. Interestingly, the overall percentage (across all buildings) of those saying the residence meets their needs increased for each option, including the location of the neighborhood in the region, the characteristics of the neighborhood itself, the location of the residence within the neighborhood, and the characteristics of the residence itself.

The "characteristics of the neighborhood itself" question speaks most directly to the potential question of the change in the neighborhood between the baseline survey and today. Notably, the percentage of respondents stating that their residence met their current household needs in this regard increased more than for any other variable, and also included significant increases for a number of individual buildings. Nexus Apartments, Club 1201, and Elmonica Condos all saw large increases in the percentage of respondents who felt the characteristics of their neighborhood suits them well.

Table 4-12 Percentage of Respondents Agreeing that Building Meets the Current Needs of Their Household (either well or very well)

\begin{tabular}{|c|c|c|c|c|c|c|}
\hline Building & Survey & $\begin{array}{c}\text { Location of } \\
\text { Neighborhoo } \\
\text { d in Region }\end{array}$ & $\begin{array}{c}\text { Characteristics } \\
\text { of the } \\
\text { Neighborhood } \\
\text { Itself }\end{array}$ & $\begin{array}{c}\text { Location of } \\
\text { Residence } \\
\text { within } \\
\text { Neighborhoo } \\
\text { d } \\
\end{array}$ & $\begin{array}{c}\text { Characteristics } \\
\text { of the } \\
\text { Residence } \\
\text { Itself } \\
\end{array}$ & n range \\
\hline \multirow{2}{*}{$\begin{array}{c}\text { East } \\
\text { Portland } \\
\text { TODs } \\
\end{array}$} & Baseline & $58 \%$ & $28 \%$ & $40 \%$ & $48 \%$ & $26-26$ \\
\hline & Wave 2 & $87 \%$ & $53 \%$ & $60 \%$ & $80 \% *$ & 15 \\
\hline \multirow{2}{*}{$\begin{array}{c}\text { Gresham } \\
\text { Central } \\
\end{array}$} & Baseline & $78 \%$ & $67 \%$ & $78 \%$ & $67 \%$ & 18 \\
\hline & Wave 2 & $100 \%$ & $80 \%$ & $87 \%$ & $80 \%$ & 15 \\
\hline \multirow{2}{*}{$\begin{array}{c}\text { Gresham } \\
\text { TODs } \\
\end{array}$} & Baseline & $90 \%$ & $77 \%$ & $93 \%$ & $94 \%$ & $30-31$ \\
\hline & Wave 2 & $93 \%$ & $87 \%$ & $87 \%$ & $97 \%$ & 30 \\
\hline \multirow{2}{*}{$\begin{array}{c}\text { Beaverton } \\
\text { Round }\end{array}$} & Baseline & $92 \%$ & $85 \%$ & $92 \%$ & $92 \%$ & 13 \\
\hline & Wave 2 & $94 \%$ & $94 \%$ & $94 \%$ & $88 \%$ & 16 \\
\hline \multirow{2}{*}{$\begin{array}{c}\text { Nexus } \\
\text { Apartments }\end{array}$} & Baseline & $82 \%$ & $82 \%$ & $85 \%$ & $80 \%$ & 141 \\
\hline & Wave 2 & $95 \% *$ & $93 \% *$ & $91 \%$ & $89 \%$ & $91-92$ \\
\hline \multirow{2}{*}{ Club 1201} & Baseline & $83 \%$ & $70 \%$ & $78 \%$ & $65 \%$ & 23 \\
\hline & Wave 2 & $95 \%$ & $93 \% *$ & $93 \%$ & $93 \% *$ & 58 \\
\hline \multirow{2}{*}{$\begin{array}{c}\text { Orenco } \\
\text { MFH }\end{array}$} & Baseline & $86 \%$ & $96 \%$ & $93 \%$ & $86 \%$ & 28 \\
\hline & Wave 2 & $89 \%$ & $94 \%$ & $97 \%$ & $89 \%$ & 36 \\
\hline \multirow{2}{*}{$\begin{array}{c}\text { Elmonica } \\
\text { Condos }\end{array}$} & Baseline & $60 \%$ & $36 \%$ & $48 \%$ & $64 \%$ & 25 \\
\hline & Wave 2 & $76 \%$ & $62 \% *$ & $72 \%$ & $66 \%$ & 29 \\
\hline \multirow{2}{*}{ Total } & Baseline & $79 \%$ & $73 \%$ & $79 \%$ & $77 \%$ & $303-305$ \\
\hline & Wave 2 & 92\%* & $87 \% *$ & $88 \% *$ & $87 \% *$ & $290-291$ \\
\hline
\end{tabular}

*Significant at $<.05$, Chi-Square 
A section of the survey asked respondents to indicate how important various factors were to them when looking for their current residence, a four-point scale ranging from 1 (not important at all) to 4 (extremely important). The percentage of respondents marking each factor as extremely important is shown in Table 4-13. Overall changes in the rating of these factors were modest between the baseline and second-wave surveys. However, the percentage of respondents who felt that sidewalks throughout the neighborhood was extremely important increased from $31 \%$ to $43 \%$, while the percentage of respondents who felt that easy access to the freeway was extremely important decreased from $22 \%$ to $16 \%$.

The survey also provided a set of statements on travel preferences, and asked respondents to indicate their level of agreement with each statement, ranging from 1 (strongly disagree) to 5 (strongly agree). Table 4-14 presents the mean agreement with each statement, with numbers closer to 5 representing greater average agreement with the statement. Only a few of the statements had significantly different mean agreement levels between the baseline and second wave surveys - agreement that "I prefer to walk rather than drive whenever possible" increased, agreement with "Getting to work without a car is a hassle" decreased, as did agreement with the statement "The price of gasoline affects the choices I make about my daily travel."

There were some differences at the TOD level between the baseline survey year and the secondwave survey. In the second wave, the East Portland TODs group was less likely to express a desire to drive, and more likely to express a preference for biking. There were few to no significant differences for travel preferences for the Gresham TODs. The Beaverton Round respondents were more likely to state that they prefer walking, and that biking can be easier than driving. The Nexus apartments respondents were a bit more likely to say they prefer walking to driving, as well as that they could manage without a car. Club 1201 respondents were actually less positive toward biking and walking in the second wave than in the baseline survey. Orenco MFH were less positive toward public transit as compared to driving. Finally, Elmonica Condos respondents were more likely to express a preference for taking transit or walking over driving, and were less likely to say they like driving. 
Table 4-13 Percentage Indicating Factors that were Extremely Important to You When Looking for Current Residence

\begin{tabular}{|c|c|c|c|c|c|c|c|c|c|c|c|}
\hline Building & Survey & $\begin{array}{c}\text { Availabilit } \\
\text { y of Off- } \\
\text { Street } \\
\text { Parking } \\
\end{array}$ & $\begin{array}{c}\text { Sidewalks } \\
\text { Throughout } \\
\text { the } \\
\text { Neighborhoo } \\
\text { d }\end{array}$ & $\begin{array}{c}\text { Bike } \\
\text { Lanes } \\
\text { and } \\
\text { Paths } \\
\text { Nearby } \\
\end{array}$ & $\begin{array}{c}\text { Easy } \\
\text { Access to } \\
\text { the } \\
\text { Freeway } \\
\end{array}$ & $\begin{array}{l}\text { Good Public } \\
\text { Transit } \\
\text { Service (bus } \\
\text { or rail) } \\
\end{array}$ & $\begin{array}{c}\text { Parks and } \\
\text { Open } \\
\text { Spaces } \\
\text { Nearby } \\
\end{array}$ & $\begin{array}{c}\text { Shopping } \\
\text { Areas within } \\
\text { Walking } \\
\text { Distance } \\
\end{array}$ & $\begin{array}{c}\text { Easy } \\
\text { Access to } \\
\text { Downtow } \\
\mathbf{n} \\
\end{array}$ & $\begin{array}{c}\text { Close to } \\
\text { Where I } \\
\text { Work } \\
\end{array}$ & $\begin{array}{c}\mathbf{n} \\
\text { range }\end{array}$ \\
\hline \multirow{2}{*}{$\begin{array}{c}\text { East } \\
\text { Portland } \\
\text { TODs } \\
\end{array}$} & Baseline & $20 \%$ & $28 \%$ & $16 \%$ & $32 \%$ & $48 \%$ & $36 \%$ & $24 \%$ & $36 \%$ & $36 \%$ & $24-25$ \\
\hline & Wave 2 & $13 \%$ & $33 \%$ & $27 \%$ & $27 \%$ & $67 \%$ & $33 \%$ & $27 \%$ & $47 \%$ & $33 \%$ & 15 \\
\hline \multirow{2}{*}{$\begin{array}{c}\text { Gresham } \\
\text { Central }\end{array}$} & Baseline & $22 \%$ & $39 \%$ & $17 \%$ & $17 \%$ & $50 \%$ & $33 \%$ & $44 \%$ & $17 \%$ & $39 \%$ & $17-18$ \\
\hline & Wave 2 & $7 \%$ & $53 \%$ & $13 \%$ & $13 \%$ & $47 \%$ & $27 \%$ & $33 \%$ & $13 \%$ & $13 \%$ & $14-15$ \\
\hline \multirow{2}{*}{$\begin{array}{c}\text { Gresham } \\
\text { TODs }\end{array}$} & Baseline & $37 \%$ & $50 \%$ & $23 \%$ & $27 \%$ & $23 \%$ & $33 \%$ & $57 \%$ & $37 \%$ & $20 \%$ & $27-30$ \\
\hline & Wave 2 & $27 \%$ & $40 \%$ & $23 \%$ & 7\%* & $27 \%$ & $43 \%$ & $37 \%$ & $27 \%$ & $30 \%$ & 30 \\
\hline \multirow{2}{*}{$\begin{array}{c}\text { Beaverton } \\
\text { Round }\end{array}$} & Baseline & $15 \%$ & $15 \%$ & $15 \%$ & $46 \%$ & $46 \%$ & $38 \%$ & $23 \%$ & $54 \%$ & $38 \%$ & 13 \\
\hline & Wave 2 & $0 \%$ & $44 \%$ & $25 \%$ & $19 \%$ & $56 \%$ & $25 \%$ & $25 \%$ & $31 \%$ & $31 \%$ & 16 \\
\hline \multirow{2}{*}{$\begin{array}{c}\text { Nexus } \\
\text { Apartments }\end{array}$} & Baseline & $18 \%$ & $26 \%$ & $14 \%$ & $19 \%$ & $53 \%$ & $35 \%$ & $36 \%$ & $25 \%$ & $42 \%$ & $\begin{array}{c}137- \\
139\end{array}$ \\
\hline & Wave 2 & $24 \%$ & $38 \%$ & $13 \%$ & $14 \%$ & $48 \%$ & $35 \%$ & $48 \%$ & $24 \%$ & $53 \%$ & $90-93$ \\
\hline \multirow{2}{*}{ Club 1201} & Baseline & $27 \%$ & $32 \%$ & $18 \%$ & $41 \%$ & $50 \%$ & $36 \%$ & $45 \%$ & $27 \%$ & $27 \%$ & $21-22$ \\
\hline & Wave 2 & $28 \%$ & $47 \%$ & $9 \%$ & $14 \% *$ & $59 \%$ & $43 \%$ & $55 \%$ & $24 \%$ & $21 \%$ & 56-58 \\
\hline \multirow{2}{*}{$\begin{array}{c}\text { Orenco } \\
\text { MFH }\end{array}$} & Baseline & $21 \%$ & $57 \%$ & $29 \%$ & $18 \%$ & $57 \%$ & $61 \%$ & $54 \%$ & $36 \%$ & $25 \%$ & 28 \\
\hline & Wave 2 & $19 \%$ & $64 \%$ & $31 \%$ & $25 \%$ & $36 \%$ & $61 \%$ & $69 \%$ & $22 \%$ & $36 \%$ & $35-36$ \\
\hline \multirow{2}{*}{$\begin{array}{c}\text { Elmonica } \\
\text { Condos }\end{array}$} & Baseline & $23 \%$ & $8 \%$ & $0 \%$ & $8 \%$ & $35 \%$ & $8 \%$ & $\mathbf{8 \%}$ & $23 \%$ & $23 \%$ & $25-26$ \\
\hline & Wave 2 & $28 \%$ & $24 \%$ & $7 \%$ & $17 \%$ & $52 \%$ & $34 \% *$ & $21 \% *$ & $28 \%$ & $31 \%$ & 29 \\
\hline \multirow{2}{*}{ Total } & Baseline & $22 \%$ & $31 \%$ & $16 \%$ & $22 \%$ & $48 \%$ & $35 \%$ & $37 \%$ & $29 \%$ & $35 \%$ & $\begin{array}{l}297- \\
301\end{array}$ \\
\hline & Wave 2 & $22 \%$ & $43 \% *$ & $16 \%$ & $16 \% *$ & $48 \%$ & $40 \%$ & $45 \%$ & $25 \%$ & $36 \%$ & $\begin{array}{c}287- \\
292 \\
\end{array}$ \\
\hline
\end{tabular}

*Significant at $<.05$, Chi-Square 


\begin{tabular}{|c|c|c|c|c|c|c|c|c|c|c|c|c|c|c|c|c|c|c|}
\hline Building & & & $\begin{array}{c}\text { Gre } \\
\text { CeI }\end{array}$ & & & & $\begin{array}{r}\text { Bea } \\
\text { Ro }\end{array}$ & $\begin{array}{l}\text { verton } \\
\text { ound }\end{array}$ & $\begin{array}{r}\mathbf{N} \\
\text { Apa }\end{array}$ & xus & & & & & & $\begin{array}{l}\text { onica } \\
\text { ondos }\end{array}$ & & otal \\
\hline Survey $\left(1^{\text {st }}=\right.$ baseline; $2^{\text {nd }}=$ wave 2$)$ & $1^{\text {st }}$ & $2^{\text {nd }}$ & $1^{\text {st }}$ & $2^{\text {nd }}$ & $1^{\text {st }}$ & $2^{\text {nd }}$ & $1^{\text {st }}$ & $2^{\text {nd }}$ & $1^{\text {st }}$ & $2^{\text {nd }}$ & $1^{\text {st }}$ & $2^{\text {nd }}$ & $1^{\text {st }}$ & $2^{\text {nd }}$ & $1^{\text {st }}$ & $2^{\text {nd }}$ & $1^{\text {st }}$ & $2^{\text {nd }}$ \\
\hline Walking can sometimes be easier for me than driving & 3.2 & 3.3 & 3.7 & 3.4 & 3.9 & 3.8 & 2.9 & 3.4 & 3.5 & 3.7 & 3.3 & 3.5 & 3.1 & 3.8 & 2.4 & 2.8 & 3.3 & 3.5 \\
\hline I would like to own at least one more car & 2.3 & $1.5^{*}$ & 1.9 & 2.5 & 1.9 & 1.9 & 2.0 & 2.0 & 1.9 & 2.1 & 1.8 & 1.6 & 1.7 & 1.5 & 1.9 & 2.0 & 1.9 & 1.9 \\
\hline Travel time is generally wasted time. & 2.9 & $2.0 *$ & 2.9 & 2.9 & 2.7 & 2.9 & 3.3 & 2.8 & 3.1 & 2.9 & 2.9 & 2.9 & 2.7 & 3.1 & 3.1 & 3.4 & 3.0 & 2.9 \\
\hline $\begin{array}{l}\text { I prefer to take transit rather than drive whenever } \\
\text { possible }\end{array}$ & 2.8 & 3.3 & 2.7 & 3.1 & 2.4 & 2.1 & 3.2 & 3.3 & 3.2 & 3.4 & 3.5 & 3.3 & 3.3 & 2.7 & 2.0 & $3.3^{*}$ & 3.0 & 3.1 \\
\hline I like riding a bike & 2.8 & 3.0 & 2.8 & 2.9 & 3.4 & 2.8 & 2.7 & 3.6 & 3.0 & 3.2 & 3.6 & 2.6* & 3.1 & 3.1 & 2.8 & 2.3 & 3.0 & 2.9 \\
\hline I use my trip to/from work productively & 3.2 & 3.5 & 2.8 & $3.5^{*}$ & 3.3 & 3.2 & 3.5 & 3.7 & 3.0 & 2.9 & 3.5 & 3.1 & 3.5 & 2.9 & 3.1 & 2.9 & 3.1 & 3.1 \\
\hline I like taking transit & 3.0 & 3.6 & 2.8 & 3.1 & 2.5 & 2.4 & 3.8 & 3.5 & 3.4 & 3.4 & 3.8 & 3.6 & 3.9 & 3.4 & 2.7 & 3.0 & 3.3 & 3.3 \\
\hline Traveling by car is safer overall than walking & 2.8 & 2.5 & 2.9 & 2.7 & 2.9 & 3.3 & 2.9 & 3.1 & 2.7 & 2.6 & 2.6 & 2.5 & 2.6 & 2.6 & 2.8 & 2.9 & 2.7 & 2.7 \\
\hline I need a car to do many of the things I like to do & 3.9 & 3.5 & 3.8 & 3.6 & 4.0 & 4.1 & 4.3 & 3.9 & 3.7 & 3.6 & 3.8 & 3.6 & 4.1 & 4.0 & 4.3 & $3.5^{*}$ & 3.9 & 3.7 \\
\hline I prefer to walk rather than drive whenever possible. & 3.0 & 2.9 & 3.2 & 3.6 & 3.8 & 3.6 & 2.8 & $3.7^{*}$ & 3.4 & $3.7^{*}$ & 3.6 & 3.4 & 3.4 & 3.8 & 2.2 & 3.1* & 3.3 & $3.5^{*}$ \\
\hline I like driving & 3.4 & 3.4 & 3.7 & 3.0 & 3.7 & 3.7 & 3.1 & 3.4 & 3.3 & 3.2 & 3.0 & 3.3 & 3.4 & 3.4 & 3.7 & $2.7^{*}$ & 3.4 & 3.2 \\
\hline I prefer to bike rather than drive whenever possible & 2.1 & $2.9 *$ & 2.3 & 2.3 & 2.3 & 2.2 & 2.0 & 2.9 & 2.4 & 2.4 & 2.5 & 2.2 & 2.3 & 2.4 & 1.8 & 2.0 & 2.3 & 2.3 \\
\hline Traveling by car is safer overall than riding a bicycle. & 3.4 & 3.3 & 3.7 & 3.9 & 3.9 & 3.7 & 4.2 & 3.8 & 3.6 & 3.5 & 3.4 & 3.5 & 3.8 & 3.7 & 3.7 & 3.4 & 3.7 & 3.6 \\
\hline $\begin{array}{c}\text { Public transit can sometimes be easier for me than } \\
\text { driving }\end{array}$ & 3.4 & 3.8 & 3.1 & 3.3 & 2.5 & 2.4 & 3.8 & 3.8 & 3.5 & 3.7 & 3.9 & 3.7 & 4.0 & $3.2^{*}$ & 3.2 & 3.4 & 3.4 & 3.4 \\
\hline I try to limit my driving to help the environment & 2.9 & $3.7^{*}$ & 3.0 & 3.3 & 3.3 & 2.9 & 3.0 & 3.3 & 3.2 & 3.3 & 3.2 & 3.2 & 3.4 & 3.3 & 2.5 & 2.7 & 3.1 & 3.2 \\
\hline Traveling by car is safer overall than taking transit. & 2.8 & 2.5 & 2.9 & 2.9 & 3.6 & 3.4 & 2.3 & 2.7 & 2.7 & 2.6 & 2.2 & 2.5 & 2.6 & 2.7 & 2.7 & 2.5 & 2.7 & 2.7 \\
\hline Getting to work without a car is a hassle & 3.0 & 2.7 & 3.7 & 3.3 & 3.9 & 3.2 & 2.8 & 2.8 & 3.3 & 3.2 & 3.4 & 2.9 & 3.1 & 3.0 & 4.0 & 3.5 & 3.4 & $3.1^{*}$ \\
\hline I like walking & 3.6 & 4.1 & 4.3 & 4.1 & 4.4 & 4.3 & 4.1 & 4.3 & 4.2 & 4.2 & 4.5 & $4.0^{*}$ & 4.5 & 4.5 & 3.5 & 4.0 & 4.1 & 4.2 \\
\hline Biking can sometimes be easier for me than driving & 2.0 & $2.9 *$ & 2.3 & 2.2 & 2.2 & 2.2 & 2.0 & $3.0^{*}$ & 2.5 & 2.6 & 2.5 & 2.4 & 2.4 & 2.3 & 1.9 & 2.0 & 2.3 & 2.4 \\
\hline $\begin{array}{c}\text { The only good thing about traveling is arriving at your } \\
\text { destination }\end{array}$ & 3.1 & $2.1^{*}$ & 2.6 & 2.5 & 3.4 & 2.9 & 3.1 & 2.4 & 2.7 & 2.7 & 2.3 & 2.7 & 2.8 & 2.8 & 2.8 & 3.0 & 2.8 & 2.7 \\
\hline
\end{tabular}




\begin{tabular}{|c|c|c|c|c|c|c|c|c|c|c|c|c|c|c|c|c|c|c|}
\hline Building & $\begin{array}{r}\text { Ea } \\
\text { Port } \\
\text { TO }\end{array}$ & $\begin{array}{l}\text { st } \\
\text { and } \\
\text { Ds }\end{array}$ & $\begin{array}{l}\text { Gres } \\
\text { Cent }\end{array}$ & & $\begin{array}{r}\text { Gre } \\
\text { TC }\end{array}$ & $\begin{array}{l}\text { ham } \\
\text { Ds }\end{array}$ & $\begin{array}{r}\text { Beav } \\
\text { Ro }\end{array}$ & & $\begin{array}{r}\mathrm{N} \\
\text { Apar }\end{array}$ & $\begin{array}{l}\text { us } \\
\text { nents }\end{array}$ & $\begin{array}{l}\mathrm{Cl} \\
12\end{array}$ & & & & Eln & $\begin{array}{l}\text { onica } \\
\text { ndos }\end{array}$ & & tal \\
\hline Survey $\left(1^{\text {st }}=\right.$ baseline; $2^{\text {nd }}=$ wave 2$)$ & $1^{\text {st }}$ & $2^{\text {nd }}$ & $1^{\text {st }}$ & $2^{\text {nd }}$ & $1^{\text {st }}$ & $2^{\text {nd }}$ & $1^{\text {st }}$ & $2^{\text {nd }}$ & $1^{\text {st }}$ & $2^{\text {nd }}$ & $1^{\text {st }}$ & $2^{\text {nd }}$ & $1^{\text {st }}$ & $2^{\text {nd }}$ & $1^{\text {st }}$ & $2^{\text {nd }}$ & $1^{\text {st }}$ & $2^{\text {nd }}$ \\
\hline $\begin{array}{l}\text { I prefer to organize my errands so that I make as few } \\
\text { trips as possible }\end{array}$ & 4.0 & 4.3 & 4.2 & 4.3 & 4.6 & 4.5 & 3.5 & 4.5* & 4.2 & 4.3 & 4.3 & 4.2 & 4.3 & 4.4 & 4.2 & 4.2 & 4.2 & 4.3 \\
\hline $\begin{array}{l}\text { The price of gasoline affects the choices I make about } \\
\text { my daily travel. }\end{array}$ & 3.5 & $2.7 *$ & 3.6 & 3.2 & 3.3 & 2.8 & 2.7 & 2.7 & 3.1 & 2.8 & 3.7 & $2.4 *$ & 3.6 & $2.3^{*}$ & 3.8 & $2.6^{*}$ & 3.3 & $2.7 *$ \\
\hline $\begin{array}{c}\text { The trip to/from work is a useful transition between } \\
\text { home and work }\end{array}$ & 3.5 & 3.9 & 3.4 & 3.5 & 3.2 & 3.2 & 3.2 & 3.5 & 3.1 & 3.2 & 3.4 & 3.1 & 3.6 & $3.0 *$ & 3.4 & 3.4 & 3.2 & 3.3 \\
\hline $\begin{array}{l}\text { Fuel efficiency is an important factor for me in } \\
\text { choosing a vehicle. }\end{array}$ & 3.9 & 4.2 & 3.9 & 4.1 & 4.1 & 4.0 & 3.5 & 4.0 & 3.9 & 4.0 & 4.2 & 3.8 & 4.4 & 4.2 & 3.8 & 4.1 & 3.9 & 4.0 \\
\hline $\begin{array}{l}\text { I often use the telephone or the Internet to avoid } \\
\text { having to travel somewhere }\end{array}$ & 3.8 & $2.7 *$ & 3.6 & 3.7 & 3.9 & 4.0 & 3.3 & 3.8 & 3.7 & $3.4^{*}$ & 3.6 & 3.5 & 3.9 & 3.8 & 3.4 & 3.4 & 3.7 & 3.5 \\
\hline $\begin{array}{l}\text { We could manage pretty well with one fewer car than } \\
\text { we have (or with no car) }\end{array}$ & 2.5 & 2.8 & 2.2 & 2.4 & 2.4 & 2.0 & 2.3 & 2.7 & 2.5 & $2.9^{*}$ & 2.3 & 2.6 & 2.5 & 2.2 & 1.8 & 2.5 & 2.4 & 2.6 \\
\hline $\begin{array}{l}\text { When I need to buy something, I usually prefer to get } \\
\text { it at the closest store possible }\end{array}$ & 3.6 & 3.9 & 3.4 & 3.4 & 3.9 & 3.7 & 3.5 & 3.6 & 3.7 & 3.7 & 3.4 & 3.5 & 3.5 & 3.4 & 3.4 & 3.7 & 3.6 & 3.6 \\
\hline $\begin{array}{c}\text { My household spends too much money on owning and } \\
\text { driving our cars. }\end{array}$ & 2.6 & 2.1 & 2.6 & 2.3 & 2.6 & 2.4 & 2.5 & 2.7 & 2.5 & 2.3 & 2.4 & 2.4 & 2.4 & 2.5 & 2.5 & 2.4 & 2.5 & 2.4 \\
\hline $\begin{array}{l}\text { It is important to me to get some physical exercise } \\
\text { every day }\end{array}$ & 4.2 & 4.4 & 4.1 & 4.1 & 4.5 & 4.4 & 4.5 & 4.4 & 4.3 & 4.2 & 4.4 & 4.3 & 4.5 & 4.5 & 4.2 & 4.0 & 4.3 & 4.3 \\
\hline n range & $\begin{array}{l}22- \\
25\end{array}$ & 15 & $\begin{array}{l}17- \\
18\end{array}$ & $\begin{array}{c}14- \\
15\end{array}$ & $\begin{array}{c}26- \\
30\end{array}$ & $\begin{array}{c}28- \\
30\end{array}$ & $\begin{array}{l}12- \\
13\end{array}$ & 16 & $\begin{array}{l}12- \\
13\end{array}$ & 16 & $\begin{array}{l}18- \\
22\end{array}$ & $\begin{array}{c}52- \\
58\end{array}$ & $\begin{array}{c}26- \\
28\end{array}$ & $\begin{array}{c}30- \\
36\end{array}$ & $\begin{array}{c}25- \\
26\end{array}$ & $27-28$ & $\begin{array}{c}283- \\
300\end{array}$ & $\begin{array}{r}273- \\
288\end{array}$ \\
\hline
\end{tabular}




\section{Exploratory Analysis}

\section{Neighborhood Change and Travel Behavior}

Using the categories of neighborhood change described in the Methodology chapter, we explored the change in commute modes and certain other travel behaviors by these change groups. We hypothesized that the TODs located in neighborhoods with the larger changes would see greater changes in travel behavior. For example, if there were major increases in the number of destinations in the adjacent neighborhood, we may expect more walking and bicycling.

Table 5-1 provides the change in the percentage of respondents who commute by driving alone, transit or an active transportation mode for each of the neighborhood change categories. By these indicators, our hypotheses are not supported with respect to land use and destination changes. For example, the TODs with the major changes in land use did see an increase in commuting by walking or bicycling, but so did the TODs with minor changes in land use. The TODs with the greatest increase in walking and bicycling infrastructure did see the largest increase in commuting by those modes. However, that finding may be dependent on the sample size, which was much larger for the TODs with major improvements. Respondents living in TODs with only minor improvements are also commuting by foot or bike more in the second-wave survey, but the increase was not statistically significant, perhaps due to the smaller number of respondents in those TODs. The TODs with the major changes in pedestrian and bicycle infrastructure also saw significant decreases in the share of respondents driving alone four to five days a week.

Table 5-1 Neighborhood Change and Commuting by Driving alone, Transit and Walk/Bike

\begin{tabular}{|c|c|c|c|c|c|c|}
\hline & Survey & $\mathbf{n}$ & $\begin{array}{c}\text { Commute by } \\
\text { Driving Alone } \\
\text { Once or More } \\
\text { per Week }\end{array}$ & $\begin{array}{c}\text { Commute by } \\
\text { Driving Alone } \\
\text { 4-5 Days per } \\
\text { Week }\end{array}$ & $\begin{array}{c}\text { Commute by } \\
\text { Transit Once } \\
\text { per Week or } \\
\text { More } \\
\end{array}$ & $\begin{array}{c}\text { Commute by } \\
\text { Walk or Bike } \\
\text { Once per Week } \\
\text { or More } \\
\end{array}$ \\
\hline \multicolumn{7}{|c|}{ Land-use change } \\
\hline \multirow{2}{*}{ Minor } & Baseline & 87 & $84 \%$ & $63 \%$ & $28 \%$ & $7 \%$ \\
\hline & Wave 2 & 79 & $73 \%$ & $42 \%$ & $39 \%$ & $34 \% *$ \\
\hline \multirow{2}{*}{ Moderate } & Baseline & 27 & $63 \%$ & $39 \%$ & $53 \%$ & $5 \%$ \\
\hline & Wave 2 & 35 & $76 \%$ & $44 \%$ & $12 \% *$ & $25 \%$ \\
\hline \multirow[b]{2}{*}{ Major } & Baseline & 187 & $71 \%$ & $58 \%$ & $33 \%$ & $10 \%$ \\
\hline & Wave 2 & 185 & $64 \%$ & $48 \%$ & $30 \%$ & $28 \% *$ \\
\hline \multicolumn{7}{|c|}{ Destinations Change } \\
\hline \multirow{2}{*}{ Minor } & Baseline & 44 & $86 \%$ & $68 \%$ & $24 \%$ & $0 \%$ \\
\hline & Wave 2 & 45 & $79 \%$ & $61 \%$ & $27 \%$ & $21 \% *$ \\
\hline \multirow{2}{*}{ Moderate } & Baseline & 194 & $72 \%$ & $60 \%$ & $33 \%$ & $10 \%$ \\
\hline & Wave 2 & 147 & $61 \% *$ & $44 \%$ & $32 \%$ & $35 \% *$ \\
\hline \multirow{2}{*}{ Major } & Baseline & 63 & $69 \%$ & $43 \%$ & $42 \%$ & $10 \%$ \\
\hline & Wave 2 & 107 & $73 \%$ & $41 \%$ & $30 \%$ & $24 \%$ \\
\hline
\end{tabular}




\begin{tabular}{|c|c|c|c|c|c|c|}
\hline & Survey & $\mathbf{n}$ & $\begin{array}{c}\text { Commute by } \\
\text { Driving Alone } \\
\text { Once or More } \\
\text { per Week }\end{array}$ & $\begin{array}{c}\text { Commute by } \\
\text { Driving Alone } \\
\text { 4-5 Days per } \\
\text { Week }\end{array}$ & $\begin{array}{c}\text { Commute by } \\
\text { Transit Once } \\
\text { per Week or } \\
\text { More }\end{array}$ & $\begin{array}{c}\text { Commute by } \\
\text { Walk or Bike } \\
\text { Once per Week } \\
\text { or More }\end{array}$ \\
\hline \multicolumn{7}{|c|}{ Walk Bike Network Change } \\
\hline \multirow{2}{*}{ None } & Baseline & 53 & $72 \%$ & $50 \%$ & $50 \%$ & $9 \%$ \\
\hline & Wave 2 & 50 & $69 \%$ & $39 \%$ & $31 \%$ & $36 \%$ \\
\hline \multirow{2}{*}{ Minor } & Baseline & 36 & $72 \%$ & $46 \%$ & $34 \%$ & $14 \%$ \\
\hline & Wave 2 & 72 & $72 \%$ & $40 \%$ & $37 \%$ & $23 \%$ \\
\hline \multirow{2}{*}{ Major } & Baseline & 212 & $75 \%$ & $61 \%$ & $30 \%$ & $7 \%$ \\
\hline & Wave 2 & 177 & $66 \%$ & $49 \%$ & $29 \%$ & $30 \% *$ \\
\hline \multicolumn{7}{|c|}{ Transit Change } \\
\hline \multirow{2}{*}{ None } & Baseline & 248 & $74 \%$ & $59 \%$ & $31 \%$ & $8 \%$ \\
\hline & Wave 2 & 249 & $67 \%$ & $47 \%$ & $31 \%$ & $28 \% *$ \\
\hline \multirow{2}{*}{ Yes } & Baseline & 53 & $72 \%$ & $50 \%$ & $50 \%$ & $9 \%$ \\
\hline & Wave 2 & 50 & $69 \%$ & $39 \%$ & $31 \%$ & $36 \% *$ \\
\hline \multicolumn{7}{|l|}{ Total } \\
\hline & Baseline & 301 & $74 \%$ & $58 \%$ & $34 \%$ & $9 \%$ \\
\hline & Wave 2 & 299 & $68 \%$ & $46 \%$ & $31 \%$ & $29 \% *$ \\
\hline
\end{tabular}

*Significant at $<.05$, Chi-Square

Table 5-2 provides the change in households with fewer cars than adults, average miles driven per week, average number of walks to stores per month, and the percentage of respondents who walk or bike to a non-work store or destination at least once per week. Similarly, these comparisons do not support our hypotheses. The neighborhood change groups do not appear to do a good job of predicting expected change for any of these variables.

Table 5-2 Neighborhood Change and Driving and Walking Factors

\begin{tabular}{|c|c|c|c|c|c|c|}
\hline & Survey & $\mathbf{n}$ & $\begin{array}{l}\text { Fewer } \\
\text { Cars } \\
\text { than } \\
\text { Adults }\end{array}$ & $\begin{array}{c}\text { Drive Miles } \\
\text { in Typical } \\
\text { Week } \\
\text { (mean) } \\
\end{array}$ & $\begin{array}{l}\text { Walk to Store } \\
\text { or Business - } \\
\text { Past } 30 \text { Days } \\
\text { (mean \# days) }\end{array}$ & $\begin{array}{c}\text { Walk or Bike to } \\
\text { Specific Non-work } \\
\text { Destination at Least 1x } \\
\text { per Week }\end{array}$ \\
\hline \multicolumn{7}{|c|}{ Land-use change } \\
\hline \multirow{2}{*}{ Minor } & Baseline & 87 & $32 \%$ & 92 & 7.7 & $72 \%$ \\
\hline & Wave 2 & 79 & $57 \% *$ & 68 & 7.2 & $59 \%$ \\
\hline \multirow{2}{*}{$\begin{array}{l}\text { Moderat } \\
\text { e }\end{array}$} & Baseline & 27 & $33 \%$ & 98 & 14.6 & $96 \%$ \\
\hline & Wave 2 & 35 & $31 \%$ & 111 & 14.0 & $89 \%$ \\
\hline \multirow{2}{*}{ Major } & Baseline & 187 & $35 \%$ & 98 & 7.1 & $65 \%$ \\
\hline & Wave 2 & 185 & $50 \% *$ & 83 & 7.2 & $68 \%$ \\
\hline \multicolumn{7}{|c|}{ Destinations Change } \\
\hline \multirow{2}{*}{ Minor } & Baseline & 44 & $23 \%$ & 142 & 3.3 & $48 \%$ \\
\hline & Wave 2 & 45 & $53 \% *$ & $80 * *$ & 3.3 & $50 \%$ \\
\hline \multirow{2}{*}{ Moderate } & Baseline & 194 & $40 \%$ & 77 & 8.4 & $71 \%$ \\
\hline & Wave 2 & 147 & $55 \% *$ & 63 & 8.7 & $68 \%$ \\
\hline
\end{tabular}




\begin{tabular}{|c|c|c|c|c|c|c|}
\hline & Survey & $\mathbf{n}$ & $\begin{array}{l}\text { Fewer } \\
\text { Cars } \\
\text { than } \\
\text { Adults }\end{array}$ & $\begin{array}{c}\text { Drive Miles } \\
\text { in Typical } \\
\text { Week } \\
\text { (mean) }\end{array}$ & $\begin{array}{l}\text { Walk to Store } \\
\text { or Business - } \\
\text { Past } 30 \text { Days } \\
\text { (mean \# days) }\end{array}$ & $\begin{array}{c}\text { Walk or Bike to } \\
\text { Specific Non-work } \\
\text { Destination at Least 1x } \\
\text { per Week }\end{array}$ \\
\hline \multirow{2}{*}{ Major } & Baseline & 63 & $25 \%$ & 125 & 9.8 & $81 \%$ \\
\hline & Wave 2 & 107 & $41 \% *$ & 108 & 9.0 & $76 \%$ \\
\hline \multicolumn{7}{|c|}{ Walk Bike Network Change } \\
\hline \multirow{2}{*}{ None } & Baseline & 53 & $42 \%$ & 76 & 10.9 & $80 \%$ \\
\hline & Wave 2 & 50 & $42 \%$ & 93 & 12.0 & $79 \%$ \\
\hline \multirow{2}{*}{ Minor } & Baseline & 36 & $19 \%$ & 146 & 5.9 & $69 \%$ \\
\hline & Wave 2 & 72 & $46 \%$ & 106 & 6.7 & $70 \%$ \\
\hline \multirow{2}{*}{ Major } & Baseline & 212 & $35 \%$ & 93 & 7.6 & $67 \%$ \\
\hline & Wave 2 & 177 & $54 \%$ & $69 * *$ & 7.5 & $64 \%$ \\
\hline \multicolumn{7}{|c|}{ Transit Change } \\
\hline \multirow{2}{*}{ None } & Baseline & 248 & $33 \%$ & 101 & 7.3 & $68 \%$ \\
\hline & Wave 2 & 249 & $51 \% *$ & $80 * *$ & 7.2 & $66 \%$ \\
\hline \multirow{2}{*}{ Yes } & Baseline & 53 & $42 \%$ & 76 & 10.9 & $80 \%$ \\
\hline & Wave 2 & 50 & $42 \%$ & 93 & 12.0 & $79 \%$ \\
\hline \multicolumn{7}{|l|}{ Total } \\
\hline & Baseline & 301 & $34 \%$ & 96 & 8.0 & $70 \%$ \\
\hline & Wave 2 & 299 & $50 \% *$ & 83 & 8.0 & $68 \%$ \\
\hline
\end{tabular}

*Significant at $<.05$, Chi-Square; ** Significant at $<.05$, independent samples t-test

\section{Other Factors Associated with Travel Behavior Change}

The analysis in the previous chapter found three overall changes between the baseline and second-wave surveys that are consistent with the objectives of TODs: (1) a reduction in the share of people commuting to work by driving alone four to five days a week; (2) an increase in the share of people walking or biking to work at least one day a week; and (3) the share of people living in low-car households (fewer cars than adults). The analysis above did not find strong relationships between these changes and changes in the surrounding neighborhoods as we measured them.

To try to uncover possible explanations for the changes, we explored the relationships between the demographics of our sample and these three travel outcomes, focusing on demographic characteristics that also changed between the two surveys. In particular, we found that the second-wave sample was more likely to be male, older, a non-student, or retired. In addition, the second-wave sample had more Asian and Hispanic respondents. However, the number of respondents in those race/ethnicity categories was small, so we created a variable for white (only) or person of color. If the demographic groups that are more prevalent in the second wave are also groups that drive alone less to work, bike more to work, or own fewer cars, that may explain the overall shifts in travel behavior. In addition, we explored whether the time living at the residence is correlated with these changes. One hypothesis would be that people living at the TODs longer may have more opportunity to become familiar with and start using other travel modes. 
The analysis is shown in Table 5-3. In general, the overall changes in travel behavior we observed are not solely explained by the demographic changes in our samples. The reduction in commuting by driving alone four to five days a week is seen in every demographic category, though only statistically significant among women, whites, non-students, and younger adults (1834). Since our second-wave sample was more male and older, these demographic trends do not explain the overall reduction in driving alone to work. Even more clearly, we observe a significant increase in walking or biking to work at least once a week in every demographic category except people 60 year or older. We also observe significant increases in low-car households among all groups except people of color, retired respondents, middle-aged adults (35-59), and people living in their home from six months to three years. 
Table 5-3 Demographics and Travel Behavior Change

\begin{tabular}{|c|c|c|c|c|c|c|c|}
\hline & & \multicolumn{2}{|c|}{$\begin{array}{c}\text { Commutes by } \\
\text { Driving Alone 4-5 } \\
\text { Days/Week } \\
\end{array}$} & \multicolumn{2}{|c|}{$\begin{array}{c}\text { Commutes by } \\
\text { Bike/Walk } \\
1 \text { Day/Week } \\
\end{array}$} & \multicolumn{2}{|c|}{$\begin{array}{c}\text { Fewer Cars than } \\
\text { Adults }\end{array}$} \\
\hline & & Baseline & 2018/19 & Baseline & 2018/19 & Baseline & 2018/19 \\
\hline \multirow[t]{4}{*}{ Gender } & Male & $55 \%$ & $47 \%$ & $9 \%$ & $34 \% *$ & $37 \%$ & $54 \% *$ \\
\hline & & 69 & 83 & 74 & 83 & 102 & 117 \\
\hline & Female & $59 \%$ & $44 \% *$ & $8 \%$ & $26 \% *$ & $32 \%$ & $43 \% *$ \\
\hline & & 137 & 105 & 148 & 107 & 198 & 157 \\
\hline \multirow{4}{*}{$\begin{array}{l}\text { Race/Ethnicit } \\
\text { y }\end{array}$} & White only & $57 \%$ & $43 \% *$ & $7 \%$ & $27 \% *$ & $29 \%$ & $47 \% *$ \\
\hline & & 158 & 118 & 166 & 119 & 224 & 190 \\
\hline & Person of color & $61 \%$ & $50 \%$ & $12 \%$ & $35 \% *$ & $48 \%$ & $51 \%$ \\
\hline & & 44 & 64 & 52 & 65 & 69 & 79 \\
\hline \multirow{6}{*}{$\begin{array}{l}\text { Non-student } \\
\text { or Retired }\end{array}$} & Non-student & $66 \%$ & $50 \% *$ & $7 \%$ & $28 \% *$ & $35 \%$ & $46 \% *$ \\
\hline & & 161 & 170 & 172 & 172 & 247 & 256 \\
\hline & Retired & & & & & $35 \%$ & $57 \%$ \\
\hline & & & & & & 31 & 56 \\
\hline & Not retired & & & & & $34 \%$ & $46 \% *$ \\
\hline & & & & & & 261 & 220 \\
\hline \multirow[t]{6}{*}{ Age } & $18-34$ & $61 \%$ & $46 \% *$ & $9 \%$ & $36 \% *$ & $30 \%$ & $50 \% *$ \\
\hline & & 107 & 89 & 112 & 90 & 131 & 107 \\
\hline & $35-59$ & $58 \%$ & $48 \%$ & $8 \%$ & $23 \% *$ & $41 \%$ & $39 \%$ \\
\hline & & 80 & 73 & 90 & 73 & 120 & 88 \\
\hline & $60+$ & $40 \%$ & $35 \%$ & $7 \%$ & $25 \%$ & $21 \%$ & $54 \% *$ \\
\hline & & 15 & 23 & 15 & 24 & 43 & 79 \\
\hline \multirow{8}{*}{$\begin{array}{l}\text { Years at } \\
\text { residence }\end{array}$} & Up to 6 months & $51 \%$ & $40 \%$ & $10 \%$ & $30 \% *$ & $32 \%$ & $55 \% *$ \\
\hline & & 74 & 43 & 82 & 43 & 105 & 53 \\
\hline & $>6$ mo. to $1 \mathrm{yr}$. & $69 \%$ & $52 \%$ & $5 \%$ & $31 \% *$ & $30 \%$ & $37 \%$ \\
\hline & & 39 & 29 & 40 & 29 & 50 & 35 \\
\hline & $>1$ yr. to 3 yr. & $62 \%$ & $52 \%$ & $10 \%$ & $30 \% *$ & $41 \%$ & $44 \%$ \\
\hline & & 61 & 56 & 67 & 56 & 94 & 80 \\
\hline & Over 3 years & $43 \%$ & $40 \%$ & $7 \%$ & $28 \% *$ & $27 \%$ & $51 \% *$ \\
\hline & & 28 & 60 & 29 & 61 & 44 & 107 \\
\hline
\end{tabular}

*Significant at $<.05$, test of two proportions 


\section{TOD Specific Findings}

It became apparent that there are a number of unique factors for each of the TODs and their specific locations that influence the changes we observed. Note that for the differences discussed below, the comparisons are generally for the same location in the baseline and second-wave surveys. Some observed differences were not statistically significant, often due to low sample sizes. In cases where we think these differences are still notable, they are included and marked with "ns" for not significant. Alternatively, differences that are significant are noted "sig."

\section{East Portland TODs}

The East Portland TODs locations (Center Commons and Broadway Vantage) exhibited some changes in the demographic makeup of respondents. In the second-wave survey, we had fewer female respondents (77\% to 57\% ns), fewer African-American respondents (42\% to $21 \% \mathrm{~ns}$ ), along with a slight shift to more respondents being employed full time (31\% to $53 \%$ ns) and a shift from very low-income respondents (from $46 \%$ to $14 \%$ [ns] making under $\$ 15,000$ per year) to more in the mid- to higher-income levels. We also noted an increase in the percentage of respondents with a driver's license ( $77 \%$ to $93 \%$ ns), and a shift from no-car households ( $31 \%$ to $19 \%$ ns) to low-car households ( $50 \%$ to $67 \%$ ns). While there was a drop in those indicating they have a physical or anxiety condition preventing them from biking (33\% to 13\% ns), we also saw an increase in those with conditions preventing them from walking outside the home ( $4 \%$ to $20 \%$ ns).

East Portland TOD respondents' travel behaviors changed in some ways. While the average reported miles driven per week was the lowest of all TODs, and remained low (51 to 46), we observed a drop in those commuting by driving alone at least once per week (from $85 \%$ to $58 \%$ $\mathrm{ns}$ ), and an increase in those commuting by walk or bike at least once per week (15\% to $50 \% \mathrm{~ns}$ ). We observed a significant increase in the percentage of respondents indicating they walked or biked to a restaurant, bar or café at least once per week (13\% to 53\%), along with a decrease in those visiting friends or family by walk or bike at least once per week (32\% to $7 \%$ sig.).

East Portland TODs residents reported satisfaction with their neighborhood increased, with a shift from $28 \%$ to $53 \%$ saying that the characteristics of the neighborhood meet their household needs well; however, this is still lower than other TODs. These residents also were the most likely to rate access to good public transit service (67\%) and easy access to downtown (47\%) as extremely important factors when looking for their current residence (both were increases since the baseline survey, but not significant). Finally, in comparison to the baseline survey, the East Portland TODs group expressed a decreased desire to drive and an increased preference for biking.

\section{Gresham Central}

The Gresham Central building was one of few buildings to get younger (from an average age of 48.9 to $39.3 \mathrm{~ns}$ ). While there was little change in terms of race and employment, the respondents in the second-wave survey were more likely to have at least a four-year degree (from 39\% to $67 \% \mathrm{~ns}$ ), and incomes shifting a bit higher. Still this building's income levels were lower than other TODs, with few respondents having household incomes over \$75,000. 
Gresham Central had a drop in those with access to a working bicycle from $100 \%$ to $40 \%$ (sig.), and was one of the few buildings to have fewer people in the second-wave survey with physical or anxiety conditions related to driving, walking, riding a bicycle or taking transit.

Like most buildings, Gresham Central had an increase in the percentage of respondents

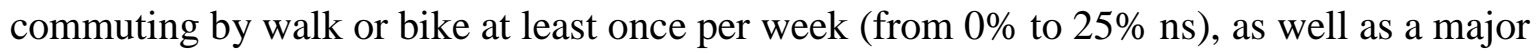
increase in walk trips per month around the neighborhood (from 6.8 to 18.3 sig), though no change in overall trips per month to businesses or stores in the neighborhood (around six trips per month in both the baseline and second-wave surveys).

Average weekly miles driven dropped from 121 to 92 on average (ns). While most people in the building who commute report using driving alone, the number who do so four to five days a week dropped slightly, while those doing so one to three days a week increased (ns). Little change in transit use was observed. Attitudes toward travel and important factors in choosing their residence changed little as well.

\section{Gresham TODs}

The Gresham TODs group (including $3^{\text {rd }}$ Central, The Beranger, Oneonta, Bridal Veil, Landmark, Three Cedars, and Central Point) was quite stable in terms of the respondents' age, gender, race/ethnicity, employment and education. There was a minor shift to slightly higher income levels, but it was not large or significant.

However, there were some changes in transportation options available, including an increase in low-car households from $20 \%$ to $55 \%$ (sig.) and a drop in the percentage of respondents with access to a bicycle ( $80 \%$ to $58 \% \mathrm{~ns}$ ). There were also several notable increases in people having physical or anxiety conditions preventing them from riding a bicycle (23\% to $43 \% \mathrm{ns)}$ ) and from using public transit ( $6 \%$ to $27 \% \mathrm{~ns}$ ). The Gresham TODs group also was an increase in those who commute by MAX at least occasionally, increasing from $9 \%$ to $37 \%$ (ns).

The Gresham TODs were the only TODs to have a statistically significant drop in the percentage of people commuting by driving alone at least once a week (from 95\% to 67\%). Overall drive miles per week dropped from 93 to 64 (ns), with the latter being the second lowest among TODs in the second wave. Perhaps relatedly, the respondents in the second-wave survey were less likely to view access to the freeway as an important factor in choosing their residence, with the percentage saying this was extremely important to them dropping from $27 \%$ to $7 \%$ (sig). This group also showed an increase in those commuting by transit or walk/bike to work at least once per week (both from $5 \%$ to $28 \% \mathrm{~ns}$ ).

This group showed an increase in the number of walks around the neighborhood (without a particular destination) (from 12.6 to 16.2 per month on average [ns]). However, there were other indicators of less walking for transportation, including a drop in the percentage of respondents saying they walk or bike to a restaurant at least once per week (61\% to $33 \%$ sig.) to a store or place to shop (from $48 \%$ to $23 \%$ ns), and to visit family or friends (from $24 \%$ to $10 \%$ ns).

\section{Beaverton Round}

The demographics of the Beaverton Round respondents showed a slight increase in the percentage of female respondents (from $38 \%$ to $56 \%$ ns) and age (41.1 to $46.3 \mathrm{~ns}$ ). However, the samples of the baseline and second-wave surveys were fairly consistent across race and ethnicity, 
employment and education. We did observe a shift toward higher income, with the top category of $\$ 150,000+$ increasing from $8 \%$ to $38 \%$ (ns), which tied it with Orenco MFH for the highest proportion of the sample in this top income category.

In terms of transportation options, the percentage of low-car households increased from $15 \%$ to $50 \%$ (ns), and the percentage of respondents with access to a working bicycle increased from $38 \%$ to $53 \%$, which was not significant but it was the only building to show an increase in this area.

We observed little change in driving alone or MAX commute trips, but did observe an increase in those who walk or bike to work or school at least once per week (from 8\% 36\% ns), which was consistent with other buildings. In fact, there were several indications of increased walk activity among Beaverton Round residents, including more no destination walks (2.9 to 7.7 per month ns), and more walk trips to businesses or stores (2.4 to $5.6 \mathrm{~ns}$ ). While these walk rates were lower than all other locations other than Elmonica Condos, they did mark increases over the baseline Beaverton Round surveys. Beaverton Round also showed a drop in weekly drive miles from 125 to 70 (sig.).

We noted several changes in factors respondents said were important about choosing their residence that suggest a walkable environment was more important to them. These include an increase in those saying having sidewalks throughout the neighborhood was extremely important (from $15 \%$ to $44 \%$ ns) and a drop in those who said easy access to a freeway was extremely important (from $46 \%$ to $19 \%$ ns). In terms of travel attitudes, we noted significant increases in those who said they would prefer to walk rather than drive, and in those saying biking can be easier than walking.

\section{The Nexus Apartments}

The Nexus apartments showed little change in gender, age, employment or income, and a slight increase in the percentage of non-white respondents, going from $26 \%$ in the baseline survey to $41 \%$ in the second-wave survey. We also saw a significant increase in respondents with a graduate degree ( $0 \%$ to $36 \%)$.

The Nexus respondents were less likely to have access to a personal bicycle (59\% to 37\% sig). However, we did see an increase in the percentage of respondents who commute by walk or bike to work (10\% to $35 \%$ sig), which was in line with other buildings. In terms of both walks with no destination (15.1 to $17.8 \mathrm{~ns}$ ) and walks to businesses or stores in the neighborhood (8 to 9 ns), The Nexus residents did not show change between the baseline and second-wave survey, but for both were toward the top of the TODs.

Respondents showed a slight drop in miles driven per week (78 to 65 ns), which was the second lowest of all TODs behind East Portland. We did see an increase in those who never commute by driving alone (from $12 \%$ to $31 \% \mathrm{~ns}$ ).

The Nexus residents showed a significant increase in happiness with the location of the neighborhood (82\% to 95\% sig.) and with the characteristics of the neighborhood (82\% to 93\% sig.) 


\section{Club 1201}

Club 1201 residents' average age increased from 49.3 to 57.4 (ns), which was the oldest average age of all TODs in study. There were slight increases in the percentage of respondents who were non-white ( $9 \%$ to $26 \%$ ns), retired ( $19 \%$ to $37 \%$ ns), and those with at least a four-year degree (48\% to $76 \%$ ). We also saw a shift to slightly higher income levels for this group.

There was a significant increase in the percentage of low-car households at Club 1201, from 22\% to $45 \%$, and a slight increase in no-car households (from $4 \%$ to $12 \%$ ns). Residents also showed several big (but not significant) increases in those with conditions preventing them from walking ( $4 \%$ to $24 \%$ ns) and riding a bicycle ( $9 \%$ to $40 \%$ ).

Unlike other buildings, Club 1201 did not show any change in the percentage of respondents commuting by walk or bike, and overall showed little change in walk trips. Miles driven per week dropped from 157 to 116 (ns). We also observed a slight increase in those who commute by MAX four to five days per week (from $6 \%$ to $24 \%$ ns).

Some of the biggest differences were in attitudes, with a significant increase in happiness with the characteristics of the neighborhood (from 70\% to 93\% saying the neighborhood suited them well) and the residence itself (from 65\% to 93\%). We also saw a drop in those who said easy access to a freeway was an extremely important factor in choosing their residence (from $41 \%$ to $14 \%$ sig.). At the same time, we saw a significant drop in those who said they like riding a bike and walking.

\section{Orenco MFH}

The Orenco MFH sample had a slightly lower percentage of women in the second-wave survey than in the baseline (63\% to 53\% ns) and a slight increase in age (51.3 to $56.3 \mathrm{~ns}$ ). While there was little change in race or education, there was an increase in the percentage of people who were retired (12\% to $38 \% \mathrm{~ns})$, as well as an increase in those in the highest-income category of $\$ 150,000$ and up (4\% to 37\% sig.). This tied it with Beaverton Round for the most high-income respondents.

In terms of transportation options, we did not observe any changes in access options or conditions preventing use. In both the baseline and second-wave surveys, Orenco residents reported the highest number of walks per month of all the TODs in the study, be it without a destination (22.2 to $23.9 \mathrm{~ns}$ ) or to a business or store in the neighborhood (14.6 to $14 \mathrm{~ns}$ ). The percentage of people reporting walking to various destinations at least once per week were higher than most TODs, including walks to stores or places to shop, with $79 \%$ reporting doing so in the baseline survey and $71 \%$ in the second-wave survey (ns).

Interestingly, there was a notable drop in the percentage of people commuting by transit at least once per week, from $53 \%$ to $12 \%$ (sig.), while those who never commute by MAX increased from $37 \%$ to $81 \%$ (ns). We noted that there was a significant drop in the mean agreement with the statement "public transit can sometimes be easier for me than driving," and miles driven per week increased from 98 to 111 (ns).

Orenco residents had very high levels of satisfaction with their neighborhood and residence, both in the baseline and in the second-wave survey. In terms of factors considered when looking for their residence, there was a drop in the percentage stating that good public transit service was 
extremely important in looking for their current residence ( $57 \%$ to $36 \%$ ns). The percentage saying that having shopping areas within walking distance was extremely important increased from $54 \%$ to $67 \%$ (ns), the latter of which was the highest of any of the TODs.

\section{Elmonica Condos}

The percentage of Elmonica Condos respondents who are women dropped from $77 \%$ to $50 \%$ (sig.), while the average age increased from 32.5 to 39.9 (sig). We also observed that the percentage of Asian respondents increased from $8 \%$ to $30 \%$ (ns). There were slight shifts in higher education and higher income, with the latter being a significant shift.

For transportation options, there was a decline in respondents with a driver's license (100\% to $81 \%$ sig) and an increase in low-car households (12\% to $50 \%$ sig). We also saw an increase in the percentage of respondents with conditions preventing them from driving ( $0 \%$ to $32 \% \mathrm{~ns}$ ), walking ( $4 \%$ to $21 \% \mathrm{~ns}$ ), and bicycling ( $4 \%$ to $25 \% \mathrm{~ns}$ ).

Walk trips at Elmonica Condos were the lowest of all TODs, with an average of only 1.8 walk trips to businesses or stores per month (no different from the baseline survey). However, we did see a drop in miles driven per week, from 156 to 74 on average (sig.), as well as a slight increase in the percentage of respondents commuting by MAX four to five days per week (13\% to $24 \%$ ns).

Elmonica Condos residents' satisfaction with their neighborhood increased significantly (36\% felt it met their household needs in the baseline survey compared to $62 \%$ in the second-wave survey), though this is on the low end of the TODs. In terms of factors affecting their choice of residence, we saw significant increases in those who said having parks and open spaces nearby was extremely important (8\% to 34\% sig), and of those saying having shopping areas within walking distance was extremely important ( $8 \%$ to $21 \%$ sig). We also saw several interesting changes in attitudes toward travel, with an increase in those who agreed that they prefer transit to driving and that they like walking, as well as a decrease in those who said they need a car and that they like driving. 


\section{Conclusions}

The primary aim of this research was to understand whether and how TOD residents' travel behavior changes over time. Our hypothesis was that as neighborhoods are built out, both around the TOD and other transit station areas, residents would have greater opportunities to use transit (along with walking and bicycling) for daily travel. We took advantage of having baseline survey data from several TODs in the Portland, OR region. These surveys started in 2005 and were usually conducted within a year or two of construction. We selected a subset of those TODs in Hillsboro, Beaverton, Portland, and Gresham to conduct a second round of surveys, 8-13 years after the baseline surveys. In selecting the TODs for the second wave, we aimed for sites that experienced a range of change in the built environment around the TOD building. This subset of buildings might by some definitions be considered transit-adjacent (TAD) as opposed to transitoriented development (TOD), due to not meeting specific levels of density, walkability and land use diversity. However, between the baseline and second wave surveys, the neighborhoods around the buildings generally transitioned over time to having greater densities of jobs and residents, and more walkable environments (more sidewalks and intersection densities).

For the sample as a whole, there were three changes between the baseline and second wave surveys that are consistent with the objectives of TODs:

(1) the share of people commuting to work by driving alone four to five days a week fell from $58 \%$ to $46 \%$, while the share never driving alone rose from $11 \%$ to $24 \%$;

(2) the share of people walking or biking to work at least one day a week rose from $9 \%$ to $29 \%$; and

(3) the share of people living in low-car households (fewer cars than adults) increased from $34 \%$ to $50 \%$, though the share of car-free household did not change.

We did not see any changes in the overall sample with respect to commuting by transit or using transit, walking, or bicycling for other non-commute trip purposes.

We examined the relationship between these travel behavior changes and changes in the built environment and transit, walking and bicycle infrastructure around the TODs. There was no evidence that places that saw more significant changes in the environment supporting transit and active transportation also experienced greater increases in those travel modes. We also explored whether changes in demographics among the TOD residents in our samples could explain the overall changes in travel behavior. They could not. The changes were generally seen across most demographic groups.

For many of our travel outcome measures, we did not observe any significant changes over time for the overall sample, including our indicators of transit use. While about one-third of our respondents commuted by transit at least one day a week (34\% in the baseline survey and 31\% in the second-wave surveys), only a small fraction (4-11\%) used transit weekly to get to other destinations. About half of our respondents did indicate they were using transit and walking more now and driving less than at their previous residence. These indicators were also consistent between the two surveys. 
We did not observe any overall increases in walking or biking to non-work destinations nearby, even in the neighborhoods with major changes to the environment. The average number of times respondents walked from home to a business in the neighborhood in the past 30 days was eight in both surveys. Weekly walking or biking to destinations for dining, shopping, recreation, socializing, and entertainment also did not change significantly over time overall. This was surprising given the significant increases in potential destinations around some of our TODs. Our sample sizes, however, at the individual TOD level may have made detecting some small changes difficult.

The residents' attitudes about travel were also very stable between the two surveys. Of the 29 statements on the survey, the only significant changes were (1) an increase in preference for walking rather than driving whenever possible; (2) a decrease in feeling that getting to work without a car is a hassle; and (3) a decrease in whether gas prices affected daily travel choices. Consistent with those changes, a higher share of respondents in the second-wave surveys indicated that having sidewalks in the neighborhood was extremely important in choosing their current home (43\% vs. 31\%) and a lower share said that easy access to the freeway was extremely important (16\% vs. 22\%). The importance of transit access remained steady at $48 \%$.

We did observe overall significant increases in the share of respondents agreeing that their current home met their needs with respect to its location in the region, the characteristics of the neighborhood, the location of their home within the neighborhood, and the characteristics of the home itself. This change may reflect some sorting out of residents (unhappy residents moved out) and/or residents adjusting their views over time. The three locations with significant increases at the TOD level in the share of respondents saying the characteristics of the neighborhood suited their household well or very well (The Nexus apartments, Club 1201, Elmonica Condos) were the three locations with major land-use changes between the baseline survey and today.

We did observe some different changes in travel behavior at the individual TOD level, or within groupings of TODs by geography. For example, residents at the Beaverton Round and Elmonica Condos reported significantly fewer miles driven per week in the second wave compared to the baseline surveys. We observed reductions at several other TODs, though the changes were not statistically significant.

There were some significant changes in the demographics of the residents in our two samples. Because we used the same survey methods in all of the surveys, these changes may reflect changes in who is living in these TODs. Overall, the sample was less likely to be female, more likely to be older (by an average of four years), more likely to be Asian or Hispanic, and less likely to be a student. Income increased as well, although it was not adjusted for inflation. In terms of education, there were more respondents with graduate degrees and fewer with just a bachelor's degree. Some of these changes may reflect overall demographic changes in the region, particularly increasing racial and ethnic diversity.

The research team is working on further analysis, including multivariate analysis, to identify specific factors that may help explain the travel behavior changes we did observe, including factors related to neighborhood change. One limitation of this analysis was our measures of the 
built environment. For example, our indicator for changes in destinations nearby was job density. Our measures of land-use change focused on building square footage. These measures may mask changes that could influence travel behavior, such as changes in usage of existing commercial space. In addition, our analysis grouped TODs based on neighborhood change. This was due, in part, to the small sample sizes at many of the individual TODs. Further analysis at the individual level or using different groupings may provide different insights. 


\section{References}

Atkinson-Palombo, Carol and Michael Kuby. The geography of advance transit-oriented development in metropolitan Phoenix, Arizona, 2000-2007. Journal of Transport Geography. Volume 19, Issue 2, March 2011, Pages 189-199

Canepa, Brian. Bursting the Bubble: Determining the Transit-Oriented Development's Walkable Limits. Transportation Research Record: Journal of the Transportation Research Board, No. 1992, Transportation Research Board of the National Academies, Washington, D.C., 2007, pp. 28-34

Cervero, R. (1998) The Transit Metropolis: A Global Inquiry. Washington DC: Island Press

Cervero, R, Arrington, G B, Smith-Heimer, J, \& Dunphy, R (2004) Transit-Oriented Development in the United States: Experiences, Challenges, and Prospects. TCRP Report No 102. Transportation Research Board: Washington, DC.

Cervero, Robert, C. Ferrell and S. Murphy. 2002. Transit-Oriented Development and Joint Development in the United States: A Literature Review. TCRP Research Results Digest Number 52, National Research Council: Washington, DC.

De Vos, Jonas, Van Acker, Veronique, and Frank Witlox. The influence of attitudes on TransitOriented Development: An explorative analysis. Transport Policy 35 (2014) 326-329.

Dill, Jennifer. Travel and transit use at Portland area transit-oriented developments (TODs). Final technical report: TransNow Budget No. 821528-4. TransNow, University of Washington, May 2006.

Dill, Jennifer. Transit Use at Transit-Oriented Developments in Portland, Oregon, Area. Transportation Research Record. Journal of the Transportation Research Board. No 2063. Washington, DC, 2008, 159-167.

Dill, Jennifer. Travel Choices at Transit-Oriented Developments: Survey Results from Portland's Eastside. Report CUS-CTS-07-01. Center for Urban Studies, Portland State University, 2007.

Dill, Jennifer. Findings from 2010 TOD Surveys. Memorandum to Metro dated October 10, 2011.

Dill, Jennifer and Nathan McNeil. Findings from 2014 TOD surveys. Memorandum to Metro dated February 8, 2015.

Dittmar, H. and S. Poticha. 2004. "Defining Transit-Oriented Development: the new regional building block." pp. 20-40 in The New Transit Town: best practices in transit-oriented development, edited by H. Dittmar and G. Ohland. Washington, D.C.: Island Press

Ewing, Reid, and Robert Cervero. Travel and the Built Environment, Journal of the American Planning Association, 76:3, 265-294. 2010.

Foth, Nicole, Manaugh, Kevin, and Ahmed M. El-Geneidy. Determinants of Mode Share over Time How Changing Transport System Affects Transit Use in Toronto, Ontario, Canada. 
Transportation Research Record: Journal of the Transportation Research Board, No. 2417, Transportation Research Board of the National Academies, Washington, D.C., 2014, pp. 67-77.

Lund, Hollie, Robert Cervero and Richard W. Willson. Travel Characteristics of TransitOriented Development in California, Final Report. 2004.

Metro Regional Government. “Transit-Oriented Development Program” Website accessible at https://www.oregonmetro.gov/tools-partners/grants-and-resources/transit-orienteddevelopment-program.

Park, Keunhyun, Reid Ewing, Brenda Sheer, and Guang Tian. The impacts of built environment characteristics of rail station areas on household travel behavior. Cities. 74, 2018, 277 283.

Renne, John L. and Ewing, Reid, "Transit-Oriented Development: An Examination of America's Transit Precincts in 2000 \& 2010" (2013). UNOTI Publications. Paper 17. https://scholarworks.uno.edu/unoti_pubs/17

Schlossberg, Marc and Nathaniel Brown. Comparing Transit-Oriented Development Sites by Walkability Indicators. Transportation Research Record: Journal of the Transportation Research Board, No. 1887, TRB, National Research Council, Washington, D.C., 2004, pp. 34-42.

Zemp, Stefan, Stauffacher, Michael, Lang, Daniel J., and Roland W. Scholz. Classifying railway stations for strategic transport and land use planning: Context matters! J. Transp. Geogr., 19 (2011), pp. 670-679. 
9. Appendix - Second-wave survey instrument 


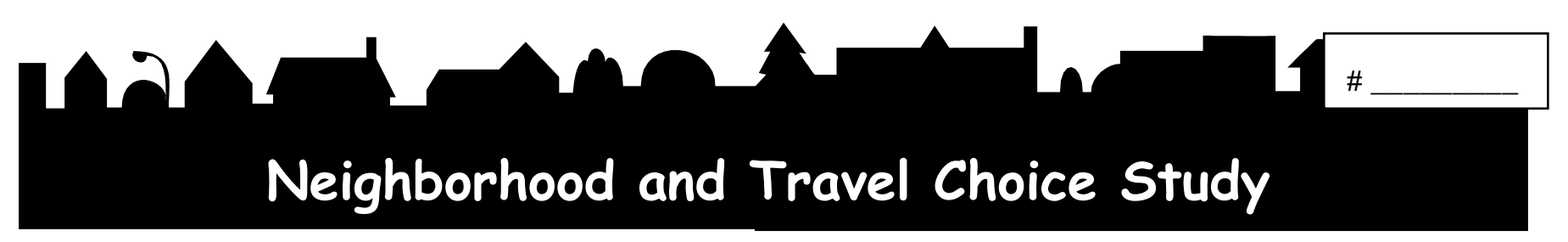

Each adult in the household should complete a separate survey. This survey is part of an effort to improve neighborhoods and transportation options in the Portland region. Your individual responses will be confidential. For questions, contact Nathan McNeil, Portland State University, nmcneil@pdx.edu or 503-725-8581.

You can also take the survey online: https://tinyurl.com/2019travelsurvey (please send by May $24^{\text {th }}$ !)

\section{A. Information on your Household and Travel}

1. Including yourself, how many people live in your household? ........

2. Of these, how many are 16 years or older?

3. How many motorized vehicles are available for use by members of your household? (do not include Zipcar/Car2Go, etc.).

\section{$\longrightarrow$ If 1 or more, where} do you park at home:
1

1

2

3

4

$5+$

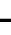

\section{2}

$3 \quad 4 \quad 5+$

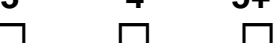

4. How many working bicycles are available $\square$ Off-street space - including with my rent

$\square$ Free on-street parking Off-street space - that I pay for separately $\square$ Other to you and members of your household?.

$\begin{array}{lll}0 & 1 \\ \square & \square\end{array}$

5. Are you a user or member of these transportation services? Check all that apply
$\square$ Ride-hail service (e.g. Uber, Lyft)
Carshare (e.g. ZipCar, Car2Go, ReachNow)
$\square$ Bike share (e.g. BIKETOWN)

\section{B. Your daily travel}

We are interested in learning about how you get around during the day. For the next few questions, we are particularly interested in trips you made on Tuesday of this week.

If you were out of town on Tuesday of this week, you may answer the questions for another day of the week. Please indicate the day here:

1. On Tuesday of this week, the first time you left your home, where were you going?
$1 \square$ To work
${ }_{2} \square$ To school (as a student)
${ }_{3} \square$ Shopping, errands, or eating out
$4 \square$ Visiting friends or family
$5 \square$ Taking someone else someplace (e.g. child to school)
$6 \square$ Entertainment or exercise
$9 \square$ I did not go anywhere on Tuesday. Please skip to Question 7 on page 3.

2. How did you get there?

$\begin{array}{ll}1 \square \text { Drove alone } & 5 \square \text { Personal bike } \\ 2 \square \text { Drove or rode } & 6 \square \text { Bike share } \\ \text { with someone else } & 7 \square \text { MAX / Streetcar } \longrightarrow \\ { }_{3} \square \text { Ride hail (Uber/Lyft) } & 8 \square \text { TriMet bus } \\ 4 \square \text { Car share vehicle } & 9 \square \text { Walked } \\ 0 \square \text { Other: } & \end{array}$

How did you get to the MAX/streetcar station from home?

${ }_{1} \square$ Walked $\quad 5 \square$ Bus

${ }_{2} \square$ Drove vehicle $\quad 6 \square$ Personal bicycle

${ }_{3} \square$ Rode with someone $7 \square$ Bike share

$4 \square$ Ride hail (Uber/Lyft) $8 \square$ Other (

3. Consider where you went after that. Where were you going?

${ }_{1} \square$ Home

${ }_{2} \square$ To work

${ }_{6} \square$ Taking someone else someplace (e.g. child to school)

${ }_{3} \square$ To school (as a student)

$4 \square$ Shopping, errands, or eating out

${ }_{5} \square$ Visiting friends or family

4. How did you get there?

${ }_{1} \square$ Drove alone

$2 \square$ Drove or rode with someone else

${ }_{3} \square$ Ride hail (Uber/Lyft)

${ }_{4} \square$ Car share vehicle
${ }_{5} \square$ Personal bike
$6 \square$ Bike share
${ }_{7} \square$ MAX / Streetcar
$8 \square$ TriMet bus
${ }_{9} \square$ Walked

Other:

$7 \square$ Entertainment or exercise

$8 \square$ No particular destination (ex: a jog, stroll, or walking a dog)

${ }_{9} \square$ Other:

How did you get from the MAX/streetcar station to your destination?
$1 \square$ Walked
Drove vehicle
Bus
Rode with someone
Personal bicycle
Bike share
Other

Ride hail (Uber/Lyft) 
5. Consider where you went after that. Where were you going?
${ }_{1} \square$ Home
${ }_{2} \square$ To work
$6 \square$ Taking someone else someplace (e.g. child to school)
${ }_{3} \square$ To school (as a student)
$4 \square$ Shopping, errands, or eating out
$7 \square$ Entertainment or exercise
${ }_{5} \square$ Visiting friends or family
${ }_{8} \square$ No particular destination (ex: a jog, stroll, or walking a dog)
$9 \square$ Other:
$\circ \square$ I did not go anywhere else on Tuesday (Please skip to Question 7.)

6. How did you get there?

${ }_{1} \square$ Drove alone

${ }_{2} \square$ Drove or rode with someone else

${ }_{3} \square$ Ride hail (Uber/Lyft)

$4 \square$ Car share vehicle

$0 \square$ Other:

$5 \square$ Personal bike
$6 \square$ Bike share
$7 \square$ MAX / Streetcar $\longrightarrow$
$8 \square$ TriMet bus
$9 \square$ Walked

${ }_{5} \square$ Personal bike

TriMet bus

If you made more than three trips on Tuesday, please use to table below to indicate where you went and how you traveled for each additional trip. If you have listed all your trips, please skip to Question 7.

\begin{tabular}{|c|c|c|c|}
\hline & Where I went & How I got there & \\
\hline $\begin{array}{l}4^{\text {th }} \text { Trip } \\
\text { (if applicable) } \\
\quad \text { or } \\
\square \text { no more trips } \\
\text { (skip to ques. 7) }\end{array}$ & $\begin{array}{l}{ }_{1} \square \text { Home }{ }_{2} \square \text { To Work } 3 \square \text { To school (as student) } \\
4 \square \text { Shopping/errands/dining } 5 \square \text { See friends/family } \\
6 \square \text { Taking someone someplace } 7 \square \text { Fun/exercise } \\
8 \square \text { No particular destination } \\
{ }_{9} \square \text { Other: }\end{array}$ & $\begin{array}{l}{ }_{1} \square \text { Drove a vehicle } \\
{ }_{2} \square \text { Rode with someone } \\
{ }_{3} \square \text { Ride hail (Uber/Lyft) } \\
{ }_{4} \square \text { Car share vehicle } \\
{ }_{0} \square \text { Other: }\end{array}$ & $\begin{array}{l}5 \square \text { Personal bike } \\
6 \square \text { Bike share } \\
7 \square \text { MAX, Streetcar } \\
{ }_{8} \square \text { TriMet bus } \\
{ }_{9} \square \text { Walked }\end{array}$ \\
\hline $\begin{array}{l}5^{\text {th }} \text { Trip } \\
\text { (if applicable) } \\
\quad \text { or } \\
\square \text { no more trips } \\
\text { (skip to ques. 7)) }\end{array}$ & $\begin{array}{l}{ }_{1} \square \text { Home }{ }_{2} \square \text { To Work } 3 \square \text { To school (as student) } \\
4 \square \text { Shopping/errands/dining } 5 \square \text { See friends/family } \\
6 \square \text { Taking someone someplace } 7 \square \text { Fun/exercise } \\
{ }_{8} \square \text { No particular destination } \\
{ }_{9} \square \text { Other: }\end{array}$ & $\begin{array}{l}{ }_{1} \square \text { Drove a vehicle } \\
{ }_{2} \square \text { Rode with someone } \\
{ }_{3} \square \text { Ride hail (Uber/Lyft) } \\
{ }_{4} \square \text { Car share vehicle } \\
{ }_{0} \square \text { Other: }\end{array}$ & $\begin{array}{l}5 \square \text { Personal bike } \\
6 \square \text { Bike share } \\
7 \square \text { MAX, Streetcar } \\
{ }_{8} \square \text { TriMet bus } \\
{ }_{9} \square \text { Walked }\end{array}$ \\
\hline $\begin{array}{l}6^{\text {th }} \text { Trip } \\
\text { (if applicable) } \\
\quad \text { or } \\
\square \text { no more trips } \\
\text { (skip to ques. 7) }\end{array}$ & $\begin{array}{l}{ }_{1} \square \text { Home }{ }_{2} \square \text { To Work }{ }_{3} \square \text { To school (as student) } \\
4 \square \text { Shopping/errands/dining } 5 \square \text { See friends/family } \\
6 \square \text { Taking someone someplace } 7 \square \text { Fun/exercise } \\
{ }_{8} \square \text { No particular destination } \\
{ }_{9} \square \text { Other: }\end{array}$ & $\begin{array}{l}1 \square \text { Drove a vehicle } \\
{ }_{2} \square \text { Rode with someone } \\
{ }_{3} \square \text { Ride hail (Uber/Lyft) } \\
{ }_{4} \square \text { Car share vehicle } \\
{ }_{0} \square \text { Other: }\end{array}$ & $\begin{array}{l}{ }_{5} \square \text { Personal bike } \\
6 \square \text { Bike share } \\
{ }_{7} \square \text { MAX, Streetcar } \\
{ }_{8} \square \text { TriMet bus } \\
{ }_{9} \square \text { Walked }\end{array}$ \\
\hline $\begin{array}{l}7^{\text {th }} \text { Trip } \\
\text { (if applicable) } \\
\quad \text { or } \\
\square \text { no more trips } \\
\text { (skip to ques. } 7 \text { ) }\end{array}$ & $\begin{array}{l}{ }_{1} \square \text { Home }{ }_{2} \square \text { To Work } 3 \square \text { To school (as student) } \\
4 \square \text { Shopping/errands/dining } 5 \square \text { See friends/family } \\
6 \square \text { Taking someone someplace } 7 \square \text { Fun/exercise } \\
{ }_{8} \square \text { No particular destination } \\
{ }_{9} \square \text { Other: }\end{array}$ & $\begin{array}{l}{ }_{1} \square \text { Drove a vehicle } \\
{ }_{2} \square \text { Rode with someone } \\
{ }_{3} \square \text { Ride hail (Uber/Lyft) } \\
{ }_{4} \square \text { Car share vehicle } \\
{ }_{0} \square \text { Other: }\end{array}$ & $\begin{array}{l}{ }_{5} \square \text { Personal bike } \\
{ }_{6} \square \text { Bike share } \\
{ }_{7} \square \text { MAX, Streetcar } \\
{ }_{8} \square \text { TriMet bus } \\
{ }_{9} \square \text { Walked }\end{array}$ \\
\hline $\begin{array}{l}8^{\text {th }} \text { Trip } \\
\text { (if applicable) } \\
\quad \text { or } \\
\square \text { no more trips } \\
\text { (skip to ques. 7) }\end{array}$ & $\begin{array}{l}{ }_{1} \square \text { Home }{ }_{2} \square \text { To Work } 3 \square \text { To school (as student) } \\
4 \square \text { Shopping/errands/dining } 5 \square \text { See friends/family } \\
6 \square \text { Taking someone someplace } 7 \square \text { Fun/exercise } \\
{ }_{8} \square \text { No particular destination } \\
{ }_{9} \square \text { Other: }\end{array}$ & $\begin{array}{l}{ }_{1} \square \text { Drove a vehicle } \\
{ }_{2} \square \text { Rode with someone } \\
{ }_{3} \square \text { Ride hail (Uber/Lyft) } \\
{ }_{4} \square \text { Car share vehicle } \\
{ }_{0} \square \text { Other: }\end{array}$ & $\begin{array}{l}{ }_{5} \square \text { Personal bike } \\
6 \square \text { Bike share } \\
{ }_{7} \square \text { MAX, Streetcar } \\
{ }_{8} \square \text { TriMet bus } \\
{ }_{9} \square \text { Walked }\end{array}$ \\
\hline $\begin{array}{l}9^{\text {th }} \text { Trip } \\
\text { (if applicable) } \\
\quad \text { or } \\
\square \text { no more trips } \\
\text { (skip to ques. 7) }\end{array}$ & $\begin{array}{l}{ }_{1} \square \text { Home }{ }_{2} \square \text { To Work } 3 \square \text { To school (as student) } \\
4 \square \text { Shopping/errands/dining } 5 \square \text { See friends/family } \\
6 \square \text { Taking someone someplace } 7 \square \text { Fun/exercise } \\
{ }_{8} \square \text { No particular destination } \\
{ }_{9} \square \text { Other: }\end{array}$ & $\begin{array}{l}1 \square \text { Drove a vehicle } \\
{ }_{2} \square \text { Rode with someone } \\
{ }_{3} \square \text { Ride hail (Uber/Lyft) } \\
{ }_{4} \square \text { Car share vehicle } \\
{ }_{0} \square \text { Other: }\end{array}$ & $\begin{array}{l}5 \square \text { Personal bike } \\
6 \square \text { Bike share } \\
7 \square \text { MAX, Streetcar } \\
{ }_{8} \square \text { TriMet bus } \\
{ }_{9} \square \text { Walked }\end{array}$ \\
\hline
\end{tabular}


7. In a typical month with good weather, how often do you walk or bike from your home to each of the following places for purposes other than work or school?

\begin{tabular}{|c|c|c|c|c|c|c|}
\hline & Never & $\begin{array}{l}\text { Less than } \\
\text { once per } \\
\text { month }\end{array}$ & $\begin{array}{l}\text { Once or } \\
\text { twice a } \\
\text { month }\end{array}$ & $\begin{array}{l}\text { About once } \\
\text { every } 2 \\
\text { weeks }\end{array}$ & $\begin{array}{l}\text { About } \\
\text { once per } \\
\text { week }\end{array}$ & $\begin{array}{c}\text { Two or } \\
\text { more times } \\
\text { per week }\end{array}$ \\
\hline Church or civic building (example: library) & $\square_{1}$ & $\square_{2}$ & $\square_{3}$ & $\square_{4}$ & $\square_{5}$ & $\square_{6}$ \\
\hline $\begin{array}{l}\text { Service provider (examples: bank, post-office, } \\
\text { hair dresser, dentist) }\end{array}$ & $\square_{1}$ & $\square_{2}$ & $\square_{3}$ & $\square_{4}$ & $\square_{5}$ & $\square 6$ \\
\hline Restaurant, bar, or coffee place & $\square_{1}$ & $\square_{2}$ & $\square_{3}$ & $\square_{4}$ & $\square_{5}$ & $\square 6$ \\
\hline Store or place to shop & $\square_{1}$ & $\square_{2}$ & $\square_{3}$ & $\square_{4}$ & $\square_{5}$ & $\square_{6}$ \\
\hline Gym or indoor recreation (ex: bowling alley) & $\square_{1}$ & $\square_{2}$ & $\square_{3}$ & $\square_{4}$ & $\square_{5}$ & $\square_{6}$ \\
\hline Park or natural open space & $\square_{1}$ & $\square_{2}$ & $\square_{3}$ & $\square_{4}$ & $\square_{5}$ & $\square_{6}$ \\
\hline Out of the house with no particular destination & $\square_{1}$ & $\square_{2}$ & $\square_{3}$ & $\square_{4}$ & $\square_{5}$ & $\square_{6}$ \\
\hline Visit friends or family at their home & $\square_{1}$ & $\square_{2}$ & $\square_{3}$ & $\square_{4}$ & $\square_{5}$ & $\square_{6}$ \\
\hline Entertainment (examples: movie, museum) & $\square_{1}$ & $\square_{2}$ & $\square_{3}$ & $\square_{4}$ & $\square_{5}$ & $\square_{6}$ \\
\hline Taking someone else to school or daycare & $\square_{1}$ & $\square_{2}$ & $\square_{3}$ & $\square_{4}$ & $\square_{5}$ & $\square_{6}$ \\
\hline $\begin{array}{l}\text { Other places besides work/school: (please } \\
\text { specify) }\end{array}$ & $\square_{1}$ & $\square_{2}$ & $\square_{3}$ & $\square_{4}$ & $\square 5$ & $\square 6$ \\
\hline
\end{tabular}

8. In a typical month with good weather, how often do you take transit (bus, MAX, or Streetcar) from your home to each of the following places for purposes other than work or school?

\begin{tabular}{|c|c|c|c|c|c|c|}
\hline & Never & $\begin{array}{l}\text { Less than } \\
\text { once per } \\
\text { month }\end{array}$ & $\begin{array}{c}\text { Once or } \\
\text { twice a } \\
\text { month }\end{array}$ & $\begin{array}{l}\text { About once } \\
\text { every } 2 \\
\text { weeks }\end{array}$ & $\begin{array}{c}\text { About } \\
\text { once per } \\
\text { week }\end{array}$ & $\begin{array}{l}\text { Two or } \\
\text { more times } \\
\text { per week }\end{array}$ \\
\hline Church or civic building (example: library) & $\square_{1}$ & $\square_{2}$ & $\square_{3}$ & $\square_{4}$ & $\square_{5}$ & $\square_{6}$ \\
\hline $\begin{array}{l}\text { Service provider (examples bank, post- } \\
\text { office, hair dresser, dentist) }\end{array}$ & $\square_{1}$ & $\square_{2}$ & $\square_{3}$ & $\square_{4}$ & $\square_{5}$ & $\square_{6}$ \\
\hline Restaurant, bar, or coffee place & $\square_{1}$ & $\square_{2}$ & $\square 3$ & $\square_{4}$ & $\square_{5}$ & $\square 6$ \\
\hline Store or place to shop & $\square_{1}$ & $\square_{2}$ & $\square_{3}$ & $\square_{4}$ & $\square_{5}$ & $\square 6$ \\
\hline Gym or indoor recreation (ex: bowling alley) & $\square_{1}$ & $\square_{2}$ & $\square_{3}$ & $\square_{4}$ & $\square_{5}$ & $\square_{6}$ \\
\hline Park or natural open space & $\square_{1}$ & $\square_{2}$ & $\square_{3}$ & $\square_{4}$ & $\square_{5}$ & $\square 6$ \\
\hline Visit friends or family at their home & $\square_{1}$ & $\square_{2}$ & $\square_{3}$ & $\square_{4}$ & $\square_{5}$ & $\square 6$ \\
\hline Entertainment (examples: movie, museum) & $\square_{1}$ & $\square_{2}$ & $\square_{3}$ & $\square_{4}$ & $\square_{5}$ & $\square_{6}$ \\
\hline Taking someone else to school or daycare & $\square_{1}$ & $\square_{2}$ & $\square_{3}$ & $\square 4$ & $\square_{5}$ & $\square_{6}$ \\
\hline $\begin{array}{l}\text { Other places besides work/school: (please } \\
\text { specify) }\end{array}$ & $\square 1$ & $\square_{2}$ & $\square_{3}$ & $\square_{4}$ & $\square_{5}$ & $\square_{6}$ \\
\hline
\end{tabular}

9. How many times in the last 30 days did you take a walk, jog, or stroll around your neighborhood - for example to get exercise or walk the dog? times in the last 30 days

10. How many times in the last 30 days did you take a walk from your home to a business or store in the neighborhood? times in the last 30 days

11. How many times in the last 30 days did you ride a bicycle from your home to a business or store in the neighborhood? times in the last 30 days

12. About how long would it take you to walk from home to the closest MAX light rail station? minutes or $\square$ Don't know

13. Does your household have a pet that needs regular walks?

Yes $\square$ No 
13. Please tell us a little bit about how recently introduced travel options, such as ride-hailing, car-sharing or bike sharing services, have changed how much you travel by transit, driving, or walking/bicycling.

\section{Due to:}

Services like

Uber or Lyft

\section{Car-sharing services}

(e.g. Zipcar, Car2Go, ReachNow) ...

Bike-sharing services

(e.g. BIKETOWN) ...
... the amount I travel by: transit

driving my own car walking or bicycling transit driving my own car walking or bicycling transit driving my own car walking or bicycling
Decreased a Decreased
lot

$$
\text { lot }
$$

$\begin{array}{lllll}\square_{1} & \square_{2} & \square_{3} & \square_{4} & \square_{5} \\ \square_{1} & \square_{2} & \square_{3} & \square_{4} & \square_{5} \\ \square_{1} & \square_{2} & \square_{3} & \square_{4} & \square_{5}\end{array}$

Did not change Increased Increased a lot

$\begin{array}{llll}\square_{1} & \square_{2} & \square_{3} & \square \\ \square_{1} & \square_{2} & \square_{3} & \square \\ \square_{1} & \square_{2} & \square_{3} & \square \\ \square_{1} & \square_{2} & \square_{3} & \square \\ \square_{1} & \square_{2} & \square_{3} & \square \\ \square_{1} & \square_{2} & \square_{3} & \square\end{array}$

14. Please think about your current daily travel and your daily travel when you lived at your previous residence not long before you moved. We would like to know about how your travel has changed, for whatever reason.

Please answer for your own travel only.
a. How much do you drive now, compared to when you lived at your previous residence? more now more now
b. How much do you use public transit (bus or rail) now, compared to when you lived at your previous residence? $\square_{1}$
c. How much do you walk in your neighborhood now, compared to when you lived at your previous residence? $\square_{1}$
d. How much do you ride a bike now, compared to when you lived at your previous residence?

$\square_{1}$

$\begin{array}{ll}\square_{2} & \square_{3} \\ \square_{2} & \square_{3} \\ \square_{2} & \square_{3} \\ \square_{2} & \square_{3}\end{array}$

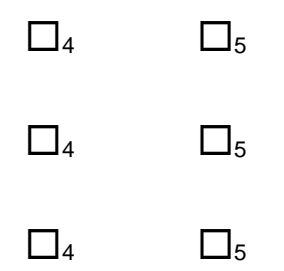
A lot less A little now less now
About the same

A little

A lot

\section{Information on your Place of Work/School and Commuting}

If you work and attend school, please provide information on your full-time activity. If both are part-time, please provide information on your place of work. Remember that your responses are confidential.

1a. Do you work or go to school outside your place of residence?

${ }_{1} \square$ Yes, I work outside of home

${ }_{2} \square$ Yes, I attend school outside of home

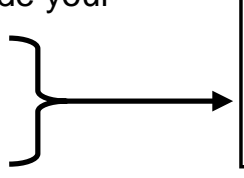

1b. If yes, where do you work or attend school?

Address or cross streets:

City:

Zip code:

${ }_{3} \square$ No, I do not work or take courses outside my home.

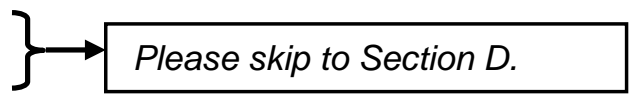

3. If you do drive (or if you were to drive) to work/school, would you have to pay to park? $\quad{ }_{1} \square$ No

4. About how long would it take you to walk from work/school to the closest:

$$
\begin{aligned}
& \text { MAX light rail station: } \\
& \text { TriMet Bus Stop: }
\end{aligned}
$$
minutes or $\square$ Don't know minutes or $\square$ Don't know

5. On average, how many days per week do you commute to work/school? days per week

6. How often do you stop somewhere on the way to work/school? days per week

7. How often do you stop somewhere on the way home from work/school? days per week 
8. At this time of year, how often do you use each of the following as your primary means of transportation to work/school? By "primary" we mean the means of transportation you use for the longest portion of your trip.

$$
\begin{array}{ccccc}
4-5 \text { days } & 2-3 \text { days } & \text { once } & 1-3 \text { days } & \text { less than } \\
\text { per week } & \text { per week } & \text { a week } & \text { a month } & \text { once a month never }
\end{array}
$$
a. Drive alone (including motorcycle)
$\square_{1}$
$\square_{2}$
$\square_{3}$
$\square_{4}$
$\square_{5} \quad \square_{6}$
b. Carpool
$\square_{2}$
$\square_{3}$
c. Carshare
d. Ride hail (Uber/Lyft)
$\square 1$
e. MAX light rail
$\square_{2}$
$\square_{3}$
$\square_{3}$

$\square_{4}$
f. TriMet bus
$\square$
g. Streetcar
h. Walk
$\square$
i. Personal Bicycle
j. Bike Share
$\square_{1}$
k. Other:
$\square_{1}$
$\square_{2}$
$\square_{2}$
$\square_{2}$
$\square_{2}$
$\square_{2}$

$\square 3$
$\square$
$\square_{4}$
$\square_{4}$
$\square_{4}$
$\square_{4}$
$\square_{4}$
$\square_{4}$
$\square$
$\square$

$\begin{array}{ll}\square_{5} & \square_{6} \\ \square_{5} & \\ \square_{5} & \square_{6} \\ \square_{5} & \square_{6} \\ \square_{5} & \square_{6} \\ \square_{5} & \square_{6} \\ \square_{5} & \square_{6} \\ \square_{5} & \square_{6} \\ \square_{5} & \square_{6} \\ \square_{5} & \square_{6}\end{array}$

9. If you currently commute by MAX light rail or streetcar at least once a month, how do you normally get ...

\begin{tabular}{|ll}
\hline from home to the station? (check one) \\
$1 \square$ Walk & $5 \square$ Ride bus \\
$2 \square$ Drive vehicle & $6 \square$ Personal bicycle \\
$3 \square$ Ride with someone & $7 \square$ Bike share \\
$4 \square$ Ride hail (Uber/Lyft) & $8 \square$ Other ( \\
$9 \square$ I do not commute by MAX or streetcar
\end{tabular}

10. Do you have a TriMet monthly pass?

\begin{tabular}{|c|c|}
\hline \multicolumn{2}{|c|}{ from station to your workplace/school? (check one } \\
\hline${ }_{1} \square$ Walk & $5 \square$ Ride bus \\
\hline${ }_{2} \square$ Drive vehicle & $6 \square$ Personal bicycle \\
\hline${ }_{3} \square$ Ride with someone & ${ }_{7} \square$ Bike share \\
\hline${ }_{4} \square$ Ride hail (Uber/Lyft) & $8 \square$ Other ( \\
\hline${ }_{9} \square$ I do not commute by & MAX or streetcar \\
\hline
\end{tabular}

$\square$ Yes $\square$ No

11. Do you have the TriMet or Hop Fastpass apps on your phone? $\square$ Yes $\square$ No $\square$ N/a $\quad \square$ Don't Know

\section{Information on Commuting from your Prior Residence}

1. Where did you live prior to this location? City: State:

Zip code:

2. For your prior residence, did you work (or go to school) at the same place as you do now?

${ }_{1} \square$ Yes $\quad{ }_{2} \square$ No $\quad{ }_{3} \square$ I did not work or go to school. (Please skip to Section E below.)

3. At your prior residence, how often did you usually use the following modes to commute to work/school?

$\begin{array}{ccccc}4-5 \text { days } & 2-3 \text { days } & \text { once } & 1-3 \text { days } & \text { less than } \\ \text { per week } & \text { per week } & \text { a week } & \text { a month } & \text { once a month never }\end{array}$
a. Drive alone (including motorcycle)
$\square_{1}$
$\square_{2}$
$\square_{3}$
$\square_{4}$
$\square_{5}$
$\square_{6}$
b. Carpool
$\square_{1}$
c. Carshare
d. Ride hail (Uber/Lyft)
$\square_{1}$
$\square_{2}$
$\square_{3}$
$\square_{4}$
$\square_{5}$
$\square_{6}$
e. Rail transit (ex: subway or light rail) $\quad \square_{1}$
$\square_{2}$
$\square_{3}$
$\square_{4}$
$\square_{5}$
$\square_{6}$
f. Bus
g. Walk
h. Personal Bicycle
$\square_{3}$
$\square 4$
$\square_{5}$
$\square_{6}$
$\square 2$
$\square_{4}$
$\square 5$
$\square_{6}$
$\square$
$\square_{2}$
$\square_{3}$
$\square_{4}$
$\square$
$\square_{5}$
$\square 6$
i. Bike Share
$\square 1$
$\square$.
$\square 3$
$\square 4$
$\square_{5}$
$\square_{6}$
j. Other:
$\square$
$\square 3$
$\square 4$
$\square_{5}$
$\square_{6}$
$\square_{3}$
$\square_{4}$
$\square_{5}$ 


\section{E. Information on your Current Place of Residence}

1. When did you move to your current residence?

month year (ex: 2004)

2. Do you rent or own your residence?

\section{Current residence}

$\square_{1}$ Rent $\quad \square_{2}$ Own

Previous residence

$\square_{1}$ Rent $\quad \square_{2}$ Own

3. How well do you think your residence and its location meet the current needs of your household?

$\begin{array}{lcccc}\text { poorly } & \text { Voorly } & \begin{array}{c}\text { Neither poorly } \\ \text { nor well }\end{array} & \text { Well } & \begin{array}{c}\text { Very } \\ \text { well }\end{array} \\ \text { Location of your neighborhood in the region .......................... } \square_{1} & \square_{2} & \square_{3} & \square_{4} & \square_{5} \\ \text { Characteristics of the neighborhood itself.............................. } \square_{1} & \square_{2} & \square_{3} & \square_{4} & \square_{5} \\ \text { Location of your residence within your neighborhood ............. } \square_{1} & \square_{2} & \square_{3} & \square_{4} & \square_{5} \\ \text { Characteristics of the residence itself ................................... } \square_{1} & \square_{2} & \square_{3} & \square_{4} & \square_{5}\end{array}$

4. In this question, we'd like to know what was important to you when you were looking for your current residence. Please indicate how important each of the factors was when you were looking for your current residence on a scale from "not at all important" to "extremely important."

\section{Not at all \\ important}

Affordable living unit

High quality living unit.

Relatively new living unit.

Good investment potential

High quality K-12 schools....

Attractive appearance of neighborhood...

Lots of off-street parking (garages or driveways)

Sidewalks throughout the neighborhood.

Good bicycle routes beyond the neighborhood.

Easy access to the freeway.

Good public transit service (bus or rail)

Parks and open spaces nearby.

Shopping areas within walking distance

Other amenities such as a pool or a community

center available nearby

Easy access to downtown

Close to where I worked

Close to friends or family

Low level of car traffic on neighborhood streets

Quiet neighborhood.

Good street lighting...

Safe neighborhood for walking

Safe neighborhood for kids to play outdoors

Low crime rate within neighborhood.

Lots of interaction among neighbors

Lots of people out and about within the neighborhood

Diverse neighbors in terms of ethnicity, race, and age.

Economic level of neighbors similar to my level.....

Other (please specify):

\section{$\square_{1}$}

$\square_{1}$

$\square$

$\square_{1}$

$\square 1$

$\square_{1}$

$\square_{1}$

$\square_{1}$

$\square_{1}$

$\square_{1}$

$\square_{1}$

$\square_{1}$

$\square_{1}$

$\square$
Extremely

important

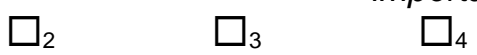

$\square_{2} \quad \square_{3} \quad \square_{4}$

$\square_{2} \quad \square_{3} \quad \square_{4}$

$\square_{2} \quad \square_{3} \quad \square_{4}$

$\square_{2} \quad \square_{3} \quad \square_{4}$

$\square_{2} \quad \square_{3} \quad \square_{4}$

$\square_{2} \quad \square_{3} \quad \square_{4}$

$\square_{2} \quad \square_{3} \quad \square_{4}$

$\square_{2} \quad \square_{3} \quad \square_{4}$

$\square_{2} \quad \square_{3} \quad \square_{4}$

$\square_{2} \quad \square_{3} \quad \square_{4}$

$\square_{2} \quad \square_{3} \quad \square_{4}$

$\square_{2} \quad \square_{3} \quad \square_{4}$

$\square_{2} \quad \square_{3} \quad \square_{4}$

$\square_{2} \quad \square_{3} \quad \square_{4}$

$\square_{2} \quad \square_{3} \quad \square_{4}$

$\square_{2} \quad \square_{3} \quad \square_{4}$

$\square_{2} \quad \square_{3} \quad \square_{4}$

$\square_{2} \quad \square_{3} \quad \square_{4}$

$\square_{2} \quad \square_{3} \quad \square_{4}$

$\square_{2} \quad \square_{3} \quad \square_{4}$

$\square_{2} \quad \square_{3} \quad \square$.

$\square_{2} \quad \square_{3} \quad \square_{4}$

$\square_{2} \quad \square_{3} \quad \square_{4}$

$\begin{array}{lll}\square_{2} & \square_{3} & \square_{4} \\ \square_{2} & \square_{3} & \square_{4} \\ \square_{2} & \square_{3} & \square_{4} \\ \square & \square_{3} & \square_{4}\end{array}$




\section{F. Information on your Travel Preferences}

We'd like to ask about your preferences with respect to daily travel. Please indicate the extent to which you agree or disagree with each of the following statements on a scale from "strongly disagree" to "strongly agree." There are no right and wrong answers; we want only your true opinions.

\begin{tabular}{|c|c|c|c|c|}
\hline Walking can sometimes be easier for me than driving ........................... $\begin{array}{c}\text { Strongly } \\
\text { disagree }\end{array}$ & $\begin{array}{l}\text { Disagree } \\
\quad \square_{2}\end{array}$ & $\begin{array}{c}\text { Neutral } \\
\square_{3}\end{array}$ & $\begin{array}{l}\text { Agree } \\
\square\end{array}$ & $\begin{array}{l}\text { Strongly } \\
\text { agree } \\
\square_{5}\end{array}$ \\
\hline I would like to own at least one more car .......................................... $\square_{1}$ & $\square_{2}$ & $\square_{3}$ & $\square_{4}$ & $\square_{5}$ \\
\hline 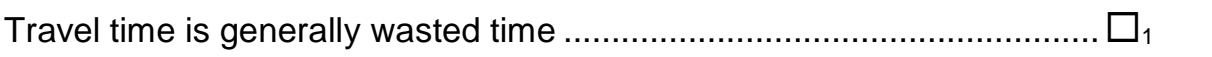 & $\square_{2}$ & $\square_{3}$ & $\square_{4}$ & $\square_{5}$ \\
\hline I prefer to take transit rather than drive whenever possible ...................... $\square_{1}$ & $\square_{2}$ & $\square_{3}$ & $\square 4$ & $\square 5$ \\
\hline 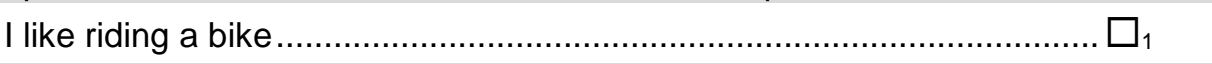 & $\square_{2}$ & $\square_{3}$ & $\square_{4}$ & $\square_{5}$ \\
\hline 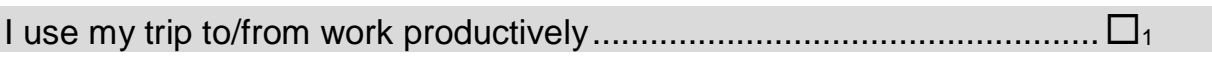 & $\square_{2}$ & $\square_{3}$ & $\square_{4}$ & $\square_{5}$ \\
\hline I like taking transit & $\square_{2}$ & $\square_{3}$ & $\square_{4}$ & $\square_{5}$ \\
\hline 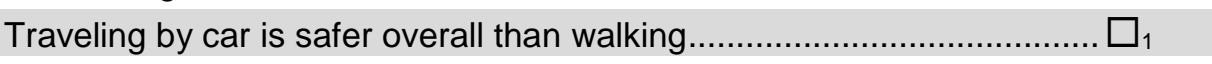 & $\square_{2}$ & $\square_{3}$ & $\square_{4}$ & $\square_{5}$ \\
\hline I need a car to do many of the things I like to do & $\square_{2}$ & $\square_{3}$ & $\square_{4}$ & $\square_{5}$ \\
\hline I prefer to walk rather than drive whenever possible.................................. $\square_{1}$ & $\square_{2}$ & $\square_{3}$ & $\square_{4}$ & $\square_{5}$ \\
\hline | like driving & $\square_{2}$ & $\square_{3}$ & $\square_{4}$ & $\square_{5}$ \\
\hline I prefer to bike rather than drive whenever possible ................................. $\square_{1}$ & $\square_{2}$ & $\square_{3}$ & $\square_{4}$ & $\square 5$ \\
\hline Traveling by car is safer overall than riding a bicycle ............................... $\square_{1}$ & $\square_{2}$ & $\square_{3}$ & $\square_{4}$ & $\square$ \\
\hline Public transit can sometimes be easier for me than driving ....................... $\square_{1}$ & $\square_{2}$ & $\square_{3}$ & $\square_{4}$ & $\square 5$ \\
\hline 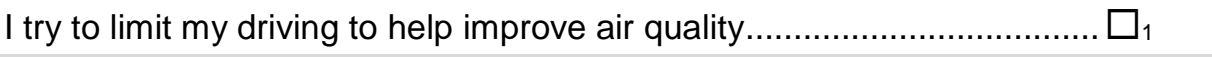 & $\square_{2}$ & $\square_{3}$ & $\square_{4}$ & $\square 5$ \\
\hline Traveling by car is safer overall than taking transit ................................... $\square_{1}$ & $\square_{2}$ & $\square_{3}$ & $\square_{4}$ & $\square_{5}$ \\
\hline 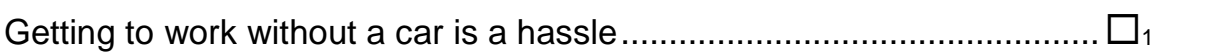 & $\square_{2}$ & $\square_{3}$ & $\square_{4}$ & $\square_{5}$ \\
\hline I like walking & $\square_{2}$ & $\square_{3}$ & $\square_{4}$ & $\square 5$ \\
\hline 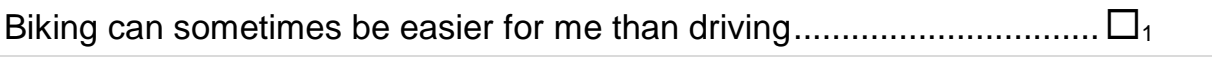 & $\square_{2}$ & $\square_{3}$ & $\square_{4}$ & $\square 5$ \\
\hline The only good thing about traveling is arriving at your destination ........... $\square_{1}$ & $\square_{2}$ & $\square_{3}$ & $\square_{4}$ & $\square$ $\square_{5}$ \\
\hline I prefer to organize my errands so that I make as few trips as possible .. $\square_{1}$ & $\square_{2}$ & $\square_{3}$ & $\square_{4}$ & $\square 5$ \\
\hline The prices of gasoline affects the choices I make about my daily travel . $\square_{1}$ & $\square_{2}$ & $\square_{3}$ & $\square_{4}$ & $\square_{5}$ \\
\hline The trip to/from work is a useful transition between home and work ........ $\square_{1}$ & $\square_{2}$ & $\square_{3}$ & $\square_{4}$ & $\square_{5}$ \\
\hline Fuel efficiency is an important factor for me in choosing a vehicle ........... $\square_{1}$ & $\square_{2}$ & $\square_{3}$ & $\square_{4}$ & $\square_{5}$ \\
\hline $\begin{array}{l}\text { I often use the telephone or the Internet to avoid having } \\
\text { to travel somewhere }\end{array}$ & $\square_{2}$ & $\square_{3}$ & $\square_{4}$ & $\square_{5}$ \\
\hline $\begin{array}{l}\text { We could manage pretty well with one fewer car than } \\
\text { we have (or with no car) }\end{array}$ & $\square_{2}$ & $\square 3$ & $\square_{4}$ & $\square 5$ \\
\hline $\begin{array}{l}\text { When I need to buy something, I usually prefer to get it } \\
\text { at the closest store possible }\end{array}$ & $\square_{2}$ & $\square_{3}$ & $\square_{4}$ & $\square 5$ \\
\hline My household spends too much money on owning and driving our cars $\square_{1}$ & $\square_{2}$ & $\square_{3}$ & $\square_{4}$ & $\square 5$ \\
\hline It is important to me to get some physical exercise every day .................. $\square_{1}$ & $\square_{2}$ & $\square_{3}$ & $\square_{4}$ & $\square_{5}$ \\
\hline New transportation services (e.g. Uber, Lyft, carshare, bike share) & & & & \\
\hline Make it easier for me to do many of the things I like to do .................... $\square_{1}$ & $\square_{2}$ & $\square 3$ & $\square 4$ & $\square 5$ \\
\hline $\begin{array}{l}\text { I like to stick to transportation modes I know rather than try new } \\
\text { services or technologies }\end{array}$ & $\square 2$ & $\square_{3}$ & $\square 4$ & $\square 5$ \\
\hline
\end{tabular}




\section{G. Your household vehicles}

1. Approximately how many miles do you drive in a typical week (including weekends)? Miles

2. Please think about the vehicles you had at your previous residence just before you moved compared to now. Did the number of vehicles available for daily travel by your household change as a result of the characteristics of your current neighborhood?

$\square_{1} \mathrm{No}$, but I/we are considering getting rid of a vehicle because of the characteristics of the neighborhood.

$\square_{2} \mathrm{No}$, but I/we are considering getting another vehicle because of the characteristics of the neighborhood.

$\square_{3}$ No, moving to this place has had no impact on the number of vehicles available to my household.

$\square_{4} \mathrm{Yes}, \mathrm{l} / \mathrm{we}$ got rid of a vehicle because of the characteristics of the neighborhood.

$\square_{5}$ Yes, I/we got an additional vehicle because of the characteristics of the neighborhood.

\section{H. Information about you}

The questions in this section ask a few things about you. These characteristics are important for analyzing your choices about where to live and your choices about daily travel. We will keep this information confidential and assure you that we will use this information only for analysis purposes.

1. What is your gender identity? $\quad{ }_{1} \square$ Female $\quad{ }_{2} \square$ Male

2. What is your age? years

3. Ethnicity or race: (check all that apply)

Black or African American

${ }_{2} \square$ Native American

${ }_{3} \square$ Pacific Islander
${ }_{4} \square$ Hispanic or latino/a

${ }_{5} \square$ White

${ }_{6} \square$ Asian

other:

4. Do you currently have a driver's license? $\quad{ }_{1} \square$ Yes $\quad{ }_{2} \square$ No

5. Current employment: (check all that apply)
${ }_{1} \square$ employed full-time

${ }_{2} \square$ employed part-time ${ }_{3} \square$ student
${ }_{4} \square$ not currently employed, but looking for work

${ }_{5} \square$ not currently employed outside the home

${ }_{6} \square$ retired

$7 \square$ other:

6. How many years of school have you completed? (Please check just one box.)

${ }_{1} \square$ Some high school or less

${ }_{2} \square$ High school diploma or GED

${ }_{3} \square$ Some college

${ }_{4} \square$ Trade/vocational school
${ }_{5} \square$ Associate degree

${ }_{6} \square$ Four-year college degree

${ }_{7} \square$ Graduate Degree

${ }_{8} \square$ Other (please specify):

7. Do you have any physical or anxiety condition that seriously limits or prevents you from doing any of the following?
a. Driving a vehicle
b. Walking outside the home
${ }_{1} \square$ No
c. Riding a bicycle
${ }_{1} \square$ No
d. Using public transit
$1 \square$ No
e. Taking a taxi or ride hail (Uber/Lyft)
$1 \square$ No

8. Approximate household income before taxes:
${ }_{2} \square$ Yes or sometimes
${ }_{2} \square$ Yes or sometimes
${ }_{2} \square$ Yes or sometimes
${ }_{2} \square$ Yes or sometimes
${ }_{2} \square$ Yes or sometimes

$\begin{array}{ll}{ }_{1} \square \text { Less than } \$ 15,000 & { }_{5} \square \$ 50,000-\$ 74,999 \\ { }_{2} \square \$ 15,000-\$ 24,999 & 6 \square \$ 75,000-\$ 99,999 \\ { }_{3} \square \$ 25,000-\$ 34,999 & { }_{7} \square \$ 100,000-\$ 149,999 \\ { }_{4} \square \$ 35,000-\$ 49,999 & { }_{8} \square \$ 150,000 \text { and over }\end{array}$

Is there anything you would like to add or explain? 